\title{
Review of the European Amphitrite (Polychaeta: Terebellidae) with description of two new species
}

\begin{abstract}
I.A. Jirkov
Department of General Ecology and Hydrobiology, Biological faculty of M.V. Lomonosov Moscow State University, Leninskije gory 1, building 12, Moscow, Russia, 119234.

E-mail:ampharete@yandex.ru
\end{abstract}

ABSTRACT: Taxonomy of six terebellids genera is discussed. It is shown that Amphitritides, Neoamphitrite and Paramphitriteonly Amphitrite are junior synonyms of Amphitrite; the difference between Amphitrite, Terebella and Eupolymnia is illustrated. The review of a substantial number of specimens of 10 species of Amphitrite known from European waters has allowed for amendments of species descriptions and updates of species distributions. Two new species are described: $A$. rzhavskyi sp.n. from the Mediterranean Sea and Scotland, UK and A. buzhinskaje sp.n. from the Sea of Japan and the Yellow Sea. $A$. rzhavskyi sp.n. has three pairs of branchiae with cirriform filaments, 17 thoracic chaetigers, four pairs of nephridia and no eyespots. A. buzhinskaje sp.n. has three pairs of arborescent branchiae, 22-23 thoracic chaetigers and all abdominal neuropodia with a single row of uncini. It is proposed to accept $A$. antarctica Monro, 1936 as species rather than subspecies of $A$. affinis. One more species from the Arctic and North Pacific is found but not named due the lack of type materials of $A$. cirrata, the most similar species. The taxonomic weight of characters used for species definitions within Amphitrite is discussed. It is shown that species range is a good taxonomic character. A comprehensive identification key to all 14 European species of Amphitrite is provided.

How to cite this article: Jirkov I.A. 2020. Review of the European Amphitrite (Polychaeta: Terebellidae) with description of two new species // Invert. Zool. Vol.17. No.4. P.311-360, Appendix. doi: 10.15298/invertzool.17.4.01

KEY WORDS: Amphitritides, Neoamphitrite, Paramphitrite, Terebella, Eupolymnia, generic characteristics, identification key, taxonomic revision, Mediterranean, North Atlantic, Sea of Japan, Yellow Sea.

\section{Ревизия европейских Amphitrite (Polychaeta: Terebellidae) с описанием двух новых видов}

\section{И.А. Жирков}

Кафедра гидробиологии, Биологический факультет Московского государственного университета им. М.В.Ломоносова, Ленинские горы 1, строение 12, Москва, Россия, 119234. E-mail:ampharete@yandex.ru

РЕЗЮМЕ: Обсуждена таксономия шести родов теребеллид. Показано, что Amphitritides, Neoamphitrite и Paramphitriteonly Amphitrite - младшие синонимы Amphitrite; проиллюстрированы различия между Amphitrite, Terebella и Eupolymnia. Изучение обширного материала 10 видов Amphitrite, известных из европейских вод, позволило составить их переописания и уточнить видовые ареалы. Описано два новых вида: $A$. 
rzhavskyi sp.n. из Средиземного моря и Великобритании и A. buzhinskaje sp.n. из Японского и Желтого морей. A. rzhavskyi sp.n. имеет три пары жабр в виде пучков коротких нитей, отходящих от общего основания, 17 торакальных щетинконосных сегментов, 4 пары нефридиев и не имеет глаз. A. buzhinskaje sp.n. имеет три пары древовидных жабр, 22-23 торакальных щетинконосных сегмента и все абдоминальные невроподии с неврохетами в один ряд. Предложено рассматривать A. antarctica Monro, 1936 как вид, а не как подвид A. affinis. Обсужден вес таксономических признаков, используемых для разделения видов Amphitrite. Показано, что ареалы видов являются хорошим таксономическим признаком. Дан ключ для определения всех 13 видов, известных из европейских вод.

Как цитировать эту статью: Jirkov I.A. 2020. Review of the European Amphitrite (Polychaeta: Terebellidae) with description of two new species // Invert. Zool. Vol.17. No.4. P.311-360, Appendix. doi: 10.15298/invertzool.17.4.01

КЛЮЧЕВЫЕ СЛОВА: Amphitritides, Neoamphitrite, Paramphitrite, Terebella, Eupolymnia, родовые признаки, определительный ключ, таксономическая ревизия, Средиземное, Японское и Желтое моря, Северная Атлантика.

\section{Introduction}

Amongst the numerous terebellid genera, some (Amphitrite Müller, 1771, Amphitritides Augener, 1922, Neoamphitrite Hessle, 1917, Paramphitrite Holthe, 1976) are so similar that there is much confusion in applying generic names to certain species. Some authors have accepted Amphitrite and Neoamphitrite as valid (Uschakov, 1955; Fauchald, 1977; Hartman, 1969; Holthe, 1986; Hartmann-Schröder, 1996), but some have not (Fauvel, 1927; Pettibone, 1954; Imajima, Hartman, 1964; Day, 1967; Hartmann-Schröder, 1971; Hutchings, Glasby 1988; Jirkov, 2001; Hutchings et al., 2017). If the genera are accepted as valid, the main difference between them is the shape of branchiae: formed as numerous simple filaments in $\mathrm{Amphi}$ trite and arborescent in Neoamphitrite. According to WoRMS (Read, Fauchald, 2020a, b), both genera are valid. To date, in WoRMS, 22 species of Amphitrite (Read, Fauchald, 2020a) and 12 species of Neoamphitrite (Read, Fauchald, 2020b) are listed as valid. However, of the 22 Amphitrite species listed as valid by Read, Fauchald (2020a), only three have cirriform branchiae; the other 19 have arborescent branchiae and thus should have been moved to Neoamphitrite, but this has not been done.
Amphitritides Augener, 1922 was separated from Amphitrite because it has two pairs of branchiae and neuropodia with uncini in double rows along most of the abdomen; however, as will be shown below, many Amphitrite species have the same characters. Other characters of both genera are similar.

Paramphitrite Holthe, 1976 was described as a genus similar to Amphitrite, but differing in having 13 thoracic segments, instead of 17 or more, and two, instead of three, pairs of branchiae. However, as will be shown below, there are Paramphitrite species with 13-14 thoracic segments, Amphitrite species with 15 or more, and some Amphitrite species previously included in both Amphitritides and Amphitrite have two pairs of branchiae. Other characters of both genera are the same.

Nine species of Amphitrite, two species of Amphitritides and two species of Paramphitrite have been reported from European waters as valid (Arvanitidis, Koukouras, 1995; HartmannSchröder, 1996; Jirkov, 2001; Castelli et al., 2008; Jirkov, Leontovich, 2013; Jirkov et al., 2018), and one more species is described below as new. Additionally, a species from the Far Eastern seas previously identified as the European Amphitrite grayi, is described as new.

The purpose of the present study is to clarify the taxonomic status and ranges of European 
species included in these genera basing on the review of a substantial number of specimens of all species of these genera known from European waters from the High Arctic to Mediterranean and the Black Sea. Generally, I follow Holthe's (1986) sense of species, as he has studied types, and Fauvel (1927) for species absent in Holthe (1986). Some remarks are given where applicable.

\section{Methods}

The study has been based mainly on the Department of General Ecology and Hydrobiology collection; studied specimens are listed in species descriptions and Table 2. All material, if not stated otherwise, is deposited at KGB and data are entered in the polychaetous database of the Department of General Ecology and Hydrobiology. The number of specimens from each locality is given in brackets.

Photographs were produced at the P.P. Shirshov Institute of Oceanology, at the Russian Academy of Science, Moscow, using a Leica DFC490 camera mounted on either a Leica M165C stereomicroscope, or a Leica DMI 4000B compound microscope; at the Department of Invertebrate Zoology, Biological Faculty, Moscow State University, using a Leica DFC425C camera mounted on a Leica DMI $5000 \mathrm{~B}$ compound microscope; at the MNCN, through a Leica DFC550 camera mounted on a Leica MZ16A stereomicroscope. In order to increase contrast, specimens were stained with methylene blue (water solution); in some cases, for the same reason, histogram equalization in Corel Photopaint was applied. All uncini in each block are from single neuropodia. For scanning electron microscopy (SEM), specimens stored in $70-75 \%$ ethanol were placed in $100 \%$ ethanol, $100 \%$ acetone then critical point dried, using $\mathrm{CO}_{2}$ as a transition fluid. Once dry, the specimens were sputter coated with gold. SEM micrographs were taken with a Camscan S-2 Cambridge instrument Scanning Electron Microscope. The SEM photographs were taken at the M.V. Lomonosov User Facilities Center, Moscow State University.
Types of four species (A. affinis Malmgren, 1866, A. gracilis (Grube, 1860), A. gray Malmgren, 1866i, A. groenlandica Malmgren, 1866) have been investigated by Holthe (1976a), investigated specimens fit his descriptions, so to my mind, there was no needs to their re-investigation. Types of $A$. cirrata (Müller, 1776), $A$. figulus (Dalyell, 1853), A. rubra (Risso, 1826) and $A$. variabilis (Risso, 1826) cannot be traced. Types of $A$. birulai Ssolowiew, 1899 have been investigated.

Abbreviations and terminology

ORGANISATIONS. APEM - APEMLtd., UK; BDUA - Biology Department of the University of Aveiro, Portugal; DGEH - Department of General Ecology and Hydrobiology Moscow Lomonosov State University, Russia; IO RAN - P.P. Shirshov Oceanological Institute of the Russian Academy of Science, Moscow, Russia; MNCN - National Museum of Natural Sciences, Madrid, Spain; ZIN — Zoological Institute of the Russian Academy of Science, St-Petersburg, Russia.

TAXONOMIC. AU - abdominal unciniger; $\mathrm{C}$ - chaetiger; $\mathrm{S}$ - segment; TC - thoracic chaetiger; TU - thoracic unciniger. The number following the abbreviation refers to the number of the segment (e.g. AU1 means the $1^{\text {st }}$ abdominal unciniger).

The nomenclature of uncinal parts used in this paper mainly follows to Noguera et al. (2010) and is shown in Fig. 1A, B.

Base - plate to which other parts are attached;

Button - short projection of the upper part of the base below the main fang;

Crest - a series of usually transverse rows of teeth above the main fang.

Heel - the posterior part of the base at the footing of the neck, froming angle to which back tendon is attached;

Main Fang - biggest tooth;

Neck - part, connecting teeth (Main Fang+ Crest) and the base;

Prow - anterior part of the uncinal base;

Tendon - sinew, attached uncinus to muscles, there are two tendons: back tendon, attached to heel, and lower tendon, attached to prow. 


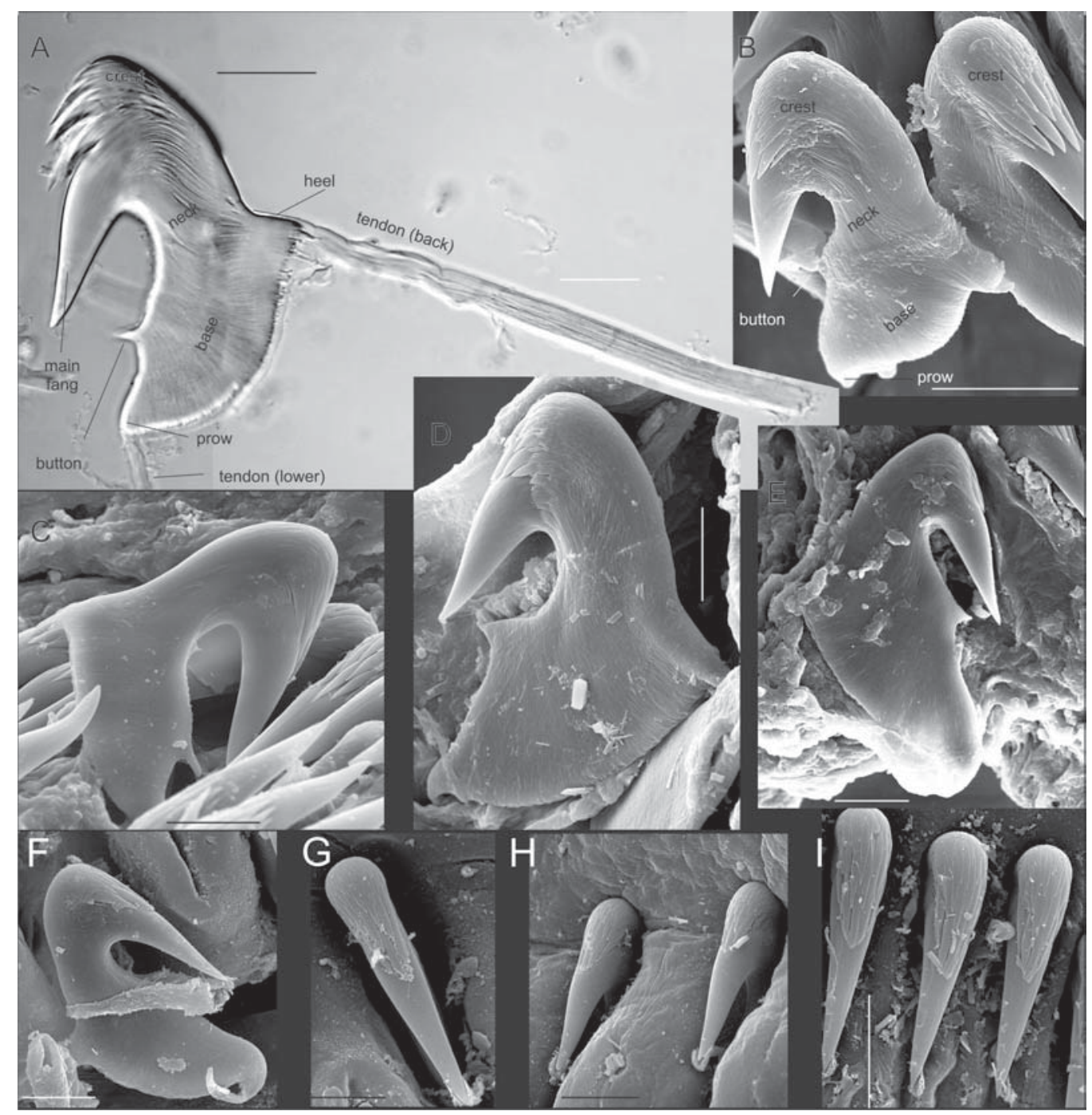

Fig. 1. Uncini and terminology of uncinal parts used in this paper (after Nogueira et al. 2010 with additions). A - Amphitrite cirrata (Müller, 1776), Alaid 8; B - A. affinis Malmgren, 1866, Alaid 8; C - A. figulus (Dalyell, 1853), Nilma 1977; D - A. groenlandica Malmgren, 1866, RT-61 26.95; E - A. cirrata (Müller, 1776), White Sea; F-H - A. rzhavskyi sp.n. TC9, APEM 487849; I - A. buzhinskaje sp.n. TC17 Vostok 838. Scale bars: $20 \mu \mathrm{m}$.

Рис. 1. Неврохеты и термины, используемые для их описания в этой статье (по Nogueira et al. 2010 с добавлениями). А - A. cirrata (Müller, 1776), Алаид 8; В - A. affinis Malmgren, 1866 Алаид 8; СA. figulus (Dalyell, 1853), Нильма 1977; D - A. groenlandica Malmgren, 1866, PT-61 26.95; Е - A. cirrata (Müller, 1776), Белое море; F-H - A. rzhavskyi sp.n. TC9, APEM 487849; I-A. buzhinskaje sp.n. ТС17, Восток 838. Масштаб: 20 мкм.

Taxonomic characters used in $A m$ phitrite species identification

The main diagnostic characters used to distinguish Amphitrite species are:

- Number of branchiae (two or three).
- Shape of branchiae: cirriform, pectinate or arborescent.

- Number of TC. If the number of TC exceeds 20 , there is variation in the number of $\mathrm{TC}$ between individuals. 
- Presence/absence of AU with uncini in double rows; if present, how many, particularly whether they are present only on some abdominal segments, or until end of the body.

- Number and position of nephridial papillae. An important character is the presence/ absence of papillae on S4 and S5. Arvanitidis \& Koukouras (1995) reported variation in the presence of nephridial papillae in S5-S7 in their Amphitritides kuehlmanni (Arvanitidis, Koukouras, 1995). If the total number of segments with papillae exceeds 10 , there is variation in the number of papillae between individuals; also, it is necessary to remember that nephridial papillae, especially posterior ones, are barely visible to invisible in small (sexually immature?) worms. At the other extreme, sexually mature females may have nephridial papillae (except anterior) replaced by inflated shields (Jirkov et al., 2018).

- Shape of uncini has some diagnostic value; however, as intraspecific variation may exceed interspecific differences, differences should only be considered where considerable and after review of intraspecific variation. Even the size of uncini may vary considerably within a single neuropodium. The shape of uncini hardly varies along the body; for example, in A. birulai, TU1, TU6 and AU16 have almost the same shape. However, as in many other genera (for example Axionice Malmgren, 1866, and Terebella), the shape of uncini often varyes along the body; it is best to compare uncini from a certain segment; if differences occur (in other genera), the uncini of TU1 always differ from the others, so it is better to compare uncini from TU1 with those from other segments.

- Some authors (for example, Hutchings, Murray A., 1984; Hutchings, Glasby, 1988) use for terebellids "dental formulas", which indicate the number of rows and teeth per row in the uncinal crest. However, in each row in the center there are large teeth, which become smaller and smaller towards the periphery, until they become indistinguishable from individual fibers. The same is true for the rows: the teeth of the lower rows are distinct, and towards the top they become smaller and smaller. The line between the tooth and the fiber is subjective, also the rows are not regular. This is all visible on the scans in Fig. 1. In addition, both the number of rows and the number of teeth vary within a single neuropodium and the size of this variability is never estimated, giving at best ranges of values obtained when counting teeth in an unknown number of uncini. Therefore, I estimate the significance of the taxonomic feature "dental formulas" low and they are not given in the descriptions.

- Some other characters may be valuable in some instances. For example, comparative sizes of the last TU and the first AU neuropodia (as in the cases of $A$. affinis / A. variabilis and A. grayi / A. buzhinskaje).

- Shape of notochaetae seems to be of a low taxonomic value at species level, at least for characters visible under a compound microscope.

\section{Results}

\section{Family Terebellidae Johnston, 1846 Genus Amphitrite Müller, 1771}

Type species: Amphitrite cirrata Müller, 1771 by subsequent designation.

Synonyms:

Amphitritides Augener, 1922 (type species Terebella gracilis Grube, 1860 by subsequent designation);

Neoamphitrite Hessle, 1917 (type species Amphitrite affinis Malmgren, 1866 by subsequent designation);

Paramphitrite Holthe, 1976 (type species Paramphitrite tetrabranchia Holthe, 1976 by original designation).

Two (on S2, S3) to three (on S2-S4) pairs of branchiae. Branchiae formed of numerous simple filaments (hereafter called cirriform branchiae), pectinate (filaments attached to stem in a row) or arborescent. Lateral lobes of S1-S3 small. Nephridial papillae start from S3. Ventral pads well separated from tori, widest pad narrower than or equal to longest thoracic uncinal row. Notopodia from S4, extending for variable number of segments, usually terminating well before pygidium. Number of TC important to species diagnoses, but not number of abdomional segments. Notochaetae straight with more or less developed keels, keels appear as wings (=limbaton) under compound microscope (Fig. 2); with serrated tips. Notochaetae usually 


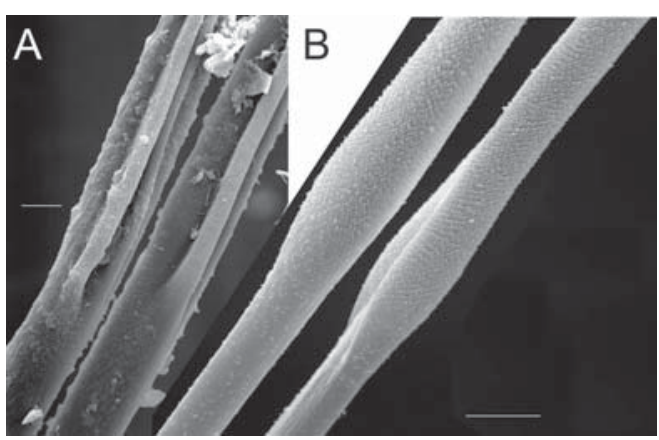

Fig. 2. Details of bilimbate notochaetae showing start of keels. A - A. cirrata (Müller, 1776), White Sea; B - A. gracilis (Grube, 1860), Gudauta. Scale bars: $10 \mu \mathrm{m}$.

Рис. 2. Детали двусторонне окаймленных нотохеты, показывающие начало килей. А-A. cirrata (Müller, 1776), Белое море; В - A. gracilis (Grube, 1860), Гудаута. Масштаб: 10 мкм.

of two lengths, long and short, but otherwise similar. Neuropodia from S5 tori, abdominal may gradually or sharply become pinnuli-like; size of tori of $\mathrm{S} 5<\mathrm{S} 6<\mathrm{S} 7$ : their dorsal margins are at almost the same level, their extension ventrally becomes gradually longer along body; from S7, for ca. 10 segments, neuropodia of same size, thereafter slowly shortening. Uncini avicular, from $\mathrm{S} 11(=\mathrm{C} 8)$ in double rows at least to end of thorax, sometimes also on some or numerous AU; uncini usually without manubrium, with two tendons or attachment point of posterior tendon slightly elongated forming short manubrium.

IDENTIFICATION KEY TO THE EUROPEAN SPECIES OF AMPHITRITE

1. 13-14 TC ............ A. birulai Ssolowiew, 1899

- 17-19 TC ...................................................... 2

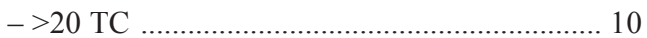

2. Branchiae comprising numerous simple unbrached filaments
- Branchiae arborescent. 6

3. Nephridial papillae on four segments (S3 and S6S8) .... 4

- Nephridial papillae on seven segments (S3 and S6$\mathrm{S} 11, \mathrm{~S} 11$ = first segment with uncini in double rows). A. gr. cirrata Müller, $1776 \ldots 4$

4. AU1 neuropodia less than half size of last TU neuropodia A. aff. cirrata Müller, 1776

- AU1 neuropodia slightly smaller than last TU neuropodia A. cirrata Müller, 1776

5. Branchial filaments arise from a short, wartlike symmetrical stem or directly from the body wall (Fig. 23A).... ...... A. fauveli Jirkov, Ravara et Cunha, 2018

- Branchial filaments arise from a large, stout asymmetrical stem (Fig. 20D).... A. rzhavskyi sp.n.

6 Two pairs of branchiae; uncini in double rows almost to pygidium ... A. gracilis (Grube, 1860)

- Three pairs of branchiae; uncini in single rows on

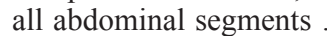

717 TC

- 19 TC ................ groenlandica Malmgren, 1866

8. Six pairs of nephridial papillae (on S3-S8) ... 9

- Nine pairs of nephridial papillae (on S3-S11) . A. edwardsii (de Quatrefages, 1865)

9. AU1 neuropodia less than half size of last TU neuropodia (Fig. 3C); TU1 uncini with massive base and short neck to main fang (Fig. 3E) ... A. affinis Malmgren, 1866

- AU1 neuropodia slightly smaller than last TU neuropodia (Fig. 24C); TU1 uncini with comparatively slim base and long neck to main tooth (Fig. 24D) ............ variabilis (Risso, 1826)

10. No abdominal segments with uncini in double rows A. grayi Malmgren, 1866

- Uncini in double rows on fewer than five abdominal segments ........ A. figulus (Dalyell, 1853)

- Uncini in double rows almost to end of abdomen 11

11. Two pairs of branchiae; 25-29 TC A. kuehlmanni (Arvanitidis et Koukouras, 1995)

- Three pairs of branchiae; 22-24 TC A. rubra (Risso, 1826)

\section{Amphitrite affinis Malmgren, 1866 Figs 1B, 3.}

Amphitrite affinis Malmgren, 1866: 377, tabl. XXII, fig. 56; Fauvel, 1927: 246-247, fig. 84 k, 1; Hartmann-

Рис. 3. Amphitrite affinis Malmgren, 1866. А — вид сбоку MI-0015 2.22, здесь и далее цифры - номера сегментов, нефридиальные папиллы указаны стрелками; однако некоторые папиллы на фото не видны (но имеются у червей), то же относится и к другим рисункам; обычно это относится к папиллам на S3, скрытыми под жабрами, поэтому отсутствие стрелок не означает отсутствие папилл на соответствующем сегменте, для полной информации необходимо обращаться к описаниям; В - вид с брюшной стороны MI-0015 2.22; C —граница торакса и абдомена MI-0015 2.22, здесь и далее последняя нотоподия показана стрелкой; D - нотохеты TC 13, Persey 859; E — uncini TU1, Persey 859; F - uncini AU10, Persey 859. Масштаб: A - 5 мм, B - 2 мм, C - 1 мм, D - 0,2 мм, E- 50 мкм, $\mathrm{F}-20$ мкм. 

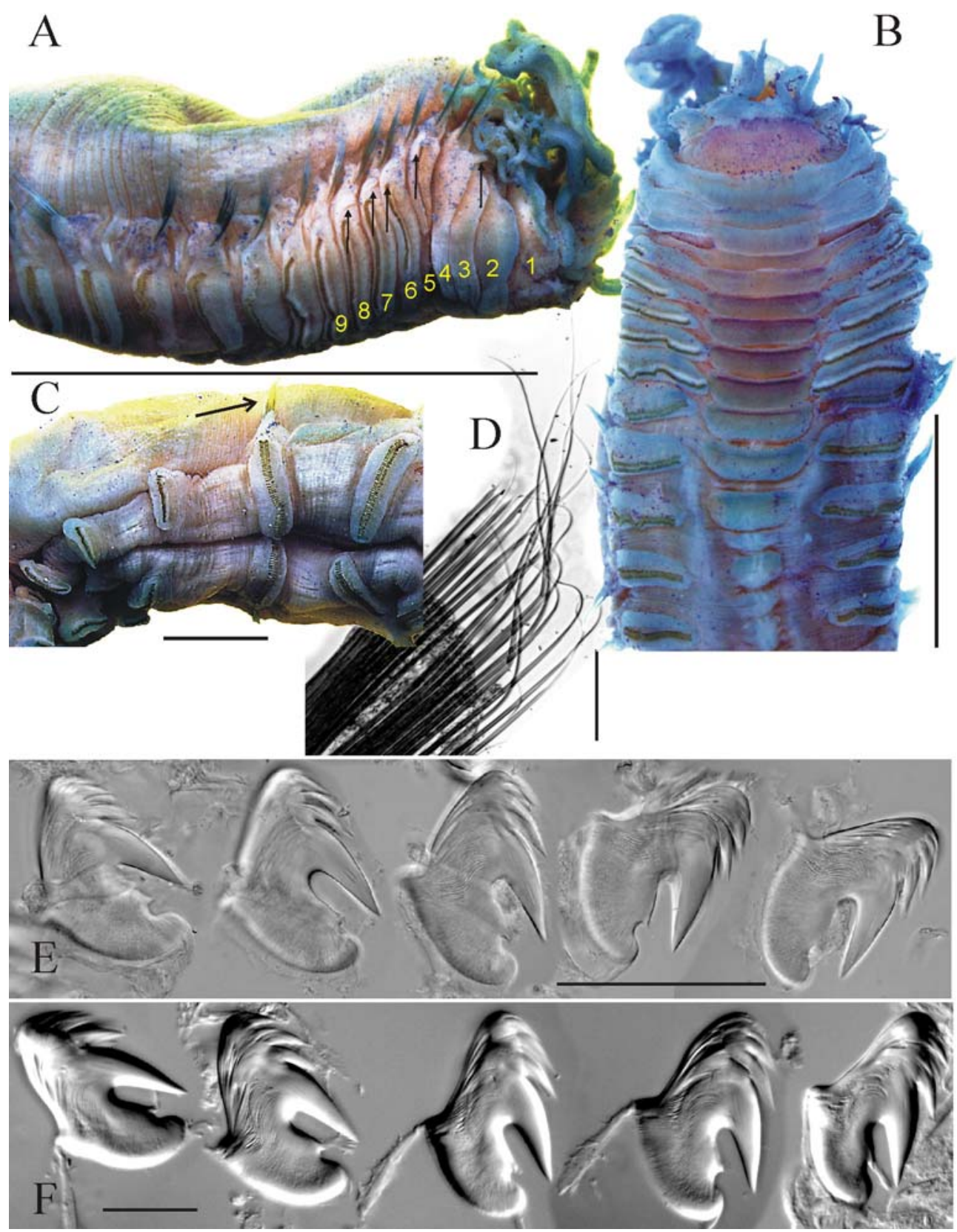

Fig. 3. Amphitrite affinis Malmgren, 1866. A - lateral view MI-0015 2.22, here and below numbers refer to number of segments, arrows point to nephridial papillae; however some papillae here and below are not visible on photos (but present in worms), usually this relates to papillae on S3 hidden by branchiae, so the absence of an arrow does not mean an absence of papillae on a certain segment, for complete information refer to descriptions; the same applies to other figures; B — ventral view MI-0015 2.22; C — thoraxabdomen border MI-0015 2.22 here and below last notopodia arrowed; D — notochaetae TC 13, Persey 859; E - uncini TU1, Persey 859; F — uncini AU10, Persey 859. Scale bars: A $-5 \mathrm{~mm}, \mathrm{~B}-2 \mathrm{~mm}, \mathrm{C}-1$ $\mathrm{mm}, \mathrm{D}-0.2 \mathrm{~mm}, \mathrm{E}-50 \mu \mathrm{m}, \mathrm{F}-20 \mu \mathrm{m}$. 
Schröder, 1971: 473; Jirkov, 1989: 126, Fig. 25.5; Jirkov, 2001: 509 - non Grainger, 1954: 521 (= Amphitrite birulai).

Neoamphitrite affinis - Zatsepin, 1948: 156, table XXXVIII, 13; Holthe, 1986: 98-100, fig. 41, map 40; Hartmann-Schröder, 1996: 514.

MATERIAL EXAMINED. 25 samples (36 specimens), from DGEH and ZIN collections (Appendix), 14-970 m.

DESCRIPTION. Up to $45 \mathrm{~mm}$ in length. Eyespots absent. Branchiae arborescent, decreasing in size posteriorly, last pair in small worms may be reduced to simple filament or even knob, or all branchiae of same size. Lateral lobes on S2-S4: small on S2, slightly developed on S3-S4, upper margin of lobes progressively more dorsal. Ventral pads smooth, well separated from neuropodia; last pad on S13. Six pairs of nephridial papillae; on S3, lateral to branchiae, large (equal in size to notopodial lobes, not visible on photo); on S4, lateral to notopodia; on S5-S8 between noto- and neuropodia, slightly posterior to row of uncini. Papillae of S4 and S5 clearly visible, less than half size of S3 papillae. Papillae of S6-S8 distinctly smaller than those of S4 and S5, inconspicuous on small worms (those with branchiae as simple filaments, at least third pair). Large females with these segments stained more or less reddish or purplish (depending on amount of methylene blue) around notopodia and papillae, while other segments do not stain (except, sometimes, lobes and lower lip); body surface around papillae inflated. Such difference in glandular contents of segments and their nephridia seems to be connected to reproduction and other functions of nephridia.

Notopodia from S4, present on 17 segments (rarely 18). Notochaetae narrow, bilimbate with serrated tips.

Neuropodia from S5; uncini facing forward; TU7-TU16 (last thoracic) with uncini in double rows (uncini face-to-face), rows well separated in all tori. Thoracic neuropodia large, almost reaching pads ventrally. Uncinal rows and neuropodia of AU1 two to three times shorter than those of last T). Uncini avicular, thoracic and abdominal similar. Tube muddy, wall thickness less than half that of inner diameter.
REMARKS. 1. The specimens examined include some collected close to the type locality (Kings Bay, Svalbard) and agree well with Holthe's (1986) description, based on the examined type.

2. Amphitrite affinis antarctica Monro, 1936 has been described and then accepted as a subspecies (Read, Fauchald, 2020g) or as a synonym (Hartman, 1959) of the nominal subspecies. According to the original description and confirmed by my examination, A. affinis antarctica differs in the number of nephridia: ten in A. affinis antarctica and only six in the nominal subspecies. This difference is more than the difference in the number of nephridia between A. affinis and A. edwardsii. The examined specimen of $A$. affinis antarctica $\left(47^{\circ} 39^{\prime} 8 \mathrm{~S} 60^{\circ} 31^{\prime} 0\right.$ $\mathrm{W}$, swimming, laminarian algae ZIN 1/43555) has the neuropodia of AU1 equal to those of the last TC. So, taking into consideration the huge gap in species range, I think these two differences justify the elevation of $A$. affinis antarctica to à species level.

DISTRIBUTION. Below tidal front (lower sublittoral) widespread in the North Polar Ba$\sin$. Southermost European reports from Trondelag, Skagerrak, Oslofjorden, Swedish west coast (Holthe, 1986).

Unlikely reports. It is reported from the Mediterranean (Alós, 1984; Papazacharias, 1991; Mikac, 2015; Faulwetter et al., 2017), but I failed to find it in collections from the Mediterranean; in the collection of MNCN, specimens identified as $A$. affinis in reality belong to $A$. variabilis, which is common in collections from the Mediterranean, so I suppose that all other reports are also based on misidentifications.

Amphitrite birulai Ssolowiew, 1899

Figs 4, 5.

Amphitrite birulai Ssolowiew, 1899: 198; Zatsepin, 1948: 156.

Paramphitrite birulai — Tzetlin et al., 1983: 182 (synonymy); Jirkov, 2001: 519.

Paramphitrite tetrabranchia Holthe, 1976: 59; 1986: 107-108, fig. 46, map 45; Parapar et al., 1991: 63-68, Fig. 2; Hartmann-Schröder, 1996: 519.

Amphitrite affinis — Grainger, 1954: 521 - non Malmgren, 1866. 

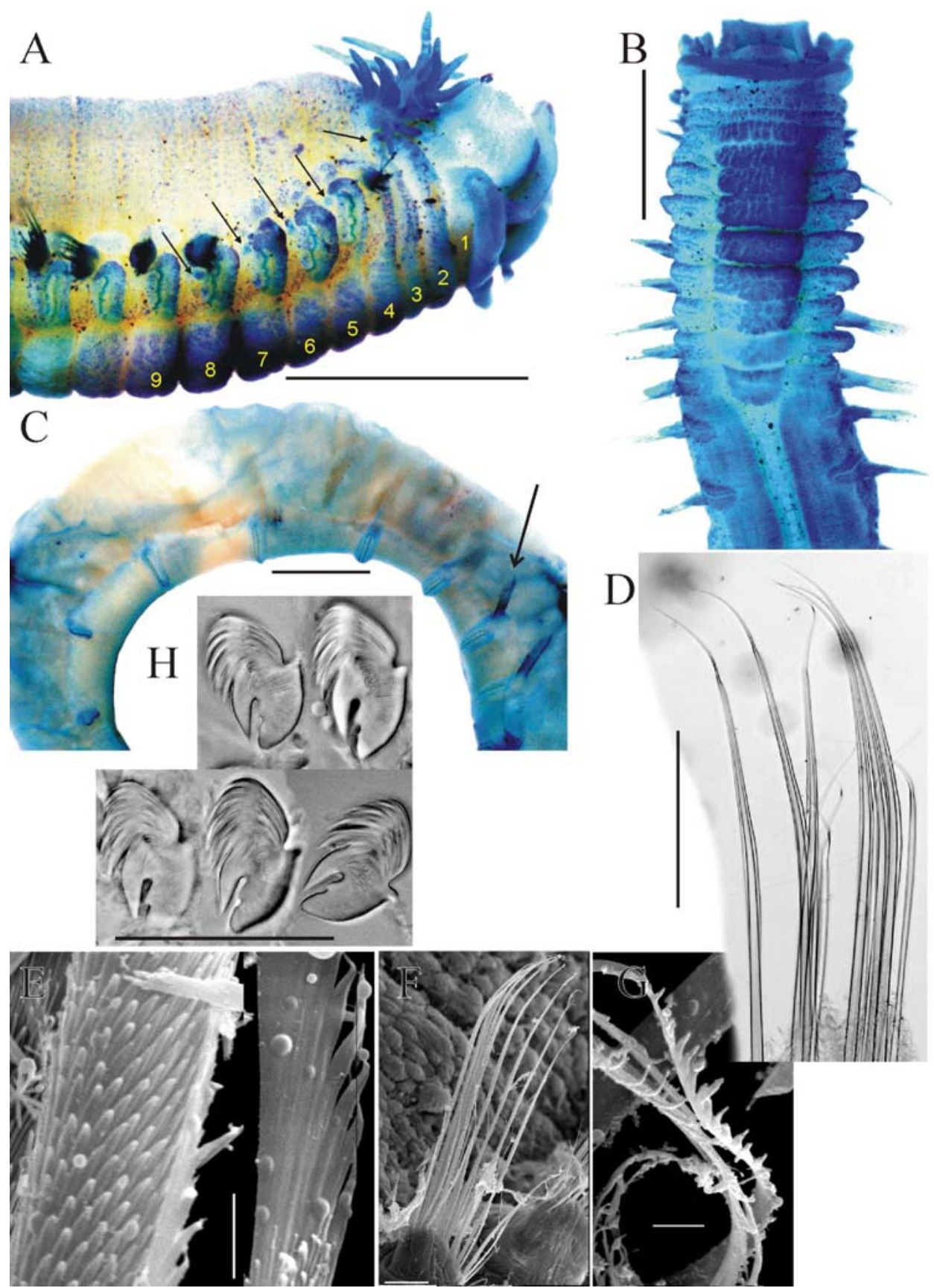

Fig. 4. Amphitrite birulai Ssolowiew, 1899. A — lateral view, White Sea; B — ventral view Black river; C thorax-abdomen border; D - notochaetae TC9, BDUA 1372.02; E-G - SEM photos of notochaetae and details of their structure, White Sea; H - uncini AU16, BDUA 149.07 06. Scale bars: A-C - $1 \mathrm{~mm}, \mathrm{D}-$ $0.2 \mathrm{~mm}, \mathrm{E}, \mathrm{G}-3 \mu \mathrm{m}, \mathrm{F}-0.1 \mathrm{~mm}, \mathrm{H}-20 \mu \mathrm{m}$.

Рис. 4. Amphitrite birulai Ssolowiew, 1899. А - вид сбоку, Белое море; В - вид с брюшной стороны Чёрная речка; C - граница торакса и абдомена; D - нотохеты TC9, BDUA 1372.02; E-G - CЭМ фото нотохет и детали их структуры, Белое море; H - uncini AU16, BDUA 149.07 06. Масштаб: А$\mathrm{C}-1$ мм, D - 0,2 мм, E, G - 3 мкм, F - 0,1 мм, $\mathrm{H}-20$ мкм. 
MATERIAL EXAMINED. Amphitrite birulai: Zoological Institute of Russian Academy of Science, 12 syntypes: ZIN 1/32181 (1 syntype), ZIN 2/32182 (6 syntypes), ZIN 3/32183 (3 syntypes), ZIN 4/32184 (1 syntype), ZIN 5/ 32185 (1 syntype); type locality, White Sea, additionally 39 samples (64 specimens) from APEM, DGEH, ZIN and BDUA collections (Appendix), 0-382 m.

DESCRIPTION. Rather small Amphitrite, up to $25 \mathrm{~mm}$ in length. Two pairs of branchiae, anterior ones distinctly larger. Branchiae pectinate with stem and several simple filaments attached to the stem on one side; filaments arranged in pairs, if more than about ten. Upper lip large, wide, slightly folded. Lower lip small. Eyespots absent or sparse in specimens studied. Lateral lobes small, slightly developed or absent; usually, lobes of S2 more developed than those of other segments. Ventral pads smooth, well separated, last pad on C9-C10. Five pairs of nephridial papillae: first pair lateral to second branchiae (on S3); and four pairs less than half size of first pair of papillae, between noto- and neuropodia of S5-S8; S4 without papillae.

Notopodia from S4, present on 13 segments (rarely 14, ZIN 2/32182). Notochaetae with narrow brims and serrated tips.

Neuropodia from C2; tori. Uncini in double rows (face-to-face, rows well separated), from C8 to C16-C18, more often C17. Neuropodia with uncini in double rows all of same size; first neuropodium with uncini in single row (whether on $\mathrm{C} 16$ or $\mathrm{C} 18$ ) half size of preceding one. Uncini avicular, crest teeth with several rows of teeth, more numerous than in other species studied here; thoracic and abdominal uncini all similar. Tube with thick wall, muddy, or covered with shell fragments.

REMARKS. 1. All 12 syntypes of $A$. birulai, including that pictured by Ssoloview (1899) with characteristic fragment of tube, have pectinate branchiae, instead of the originally described cirriform morphology.

2. The number of segments with neuropodia with double rows of uncini is constant within species, if they end before C24. A. birulai however shows variation; occasionally, some spec- imens from the same sample have different numbers of segments with uncini in double rows. For example, there are specimens with uncini in double rows to C16: APEM 40460 (1 sp.), APEM 40591 (1 sp.), APEM 41850 (1 sp.), as well as uncini in double rows to C18: APEM 41807 (1 sp.), APEM 41850 (3 sp.), DBUA0001371.03 (1 sp.)

3. Initially, I considered the distribution of A. birulai too wide for a single species. However, I have found only one difference between specimens from widely separated locations: the syntypes of $A$. birulai have muddy, thick-walled tubes, while specimens from BDUA (Portugal) have tubes without mud, covered by shell fragments. However, a specimen collected near Norway (Sygna 10-2) has its tube covered with sand and mud. Unfortunately, other specimens have no tubes. The morphology of all specimens is very similar. The shape of the uncini varies, but the difference between specimens from the White Sea and Iberian waters do not exceed variation within the White Sea or even within single neuropodia. However, most of the material examined was collected in the White Sea and only single or a few specimens are available from other localities, often in poor condition.

4. Studied here specimens collected near the type locality of Paramphitrite tetrabranchia $\left(60^{\circ} 23^{\prime} \mathrm{N}, 05^{\circ} 03^{\prime} \mathrm{E}\right.$, depth $92-100 \mathrm{~m} ; 60^{\circ} 33^{\prime}$ $\mathrm{N}, 05^{\circ} 01^{\prime} \mathrm{E}$, depth $55 \mathrm{~m}$, and NW of Bergen, $138 \mathrm{~m}$ ) do not differ from the original description and later re-description. Although I have not examined types of $P$. tetrabranchia, I believe that, for the present time, it is reasonable to accept $P$. tetrabranchia as junior synonym of $A$. birulai. Otherwise, animals assigned to each name would have no morphological differences between them.

5. Holthe (1976) wrote in his description of Paramphitrite tetrabranchia Holthe (1976: 59) "Prostomium-peristomium without eyes" but later (Holthe, 1986), based on more extensive material from the same species, he wrote (Holthe, 1986: 107), "eyespots present". Parapar et al (1991) also stated that eyespots were present. The specimens studied were fixed and stored in different ways; it is not yet possible to determine 


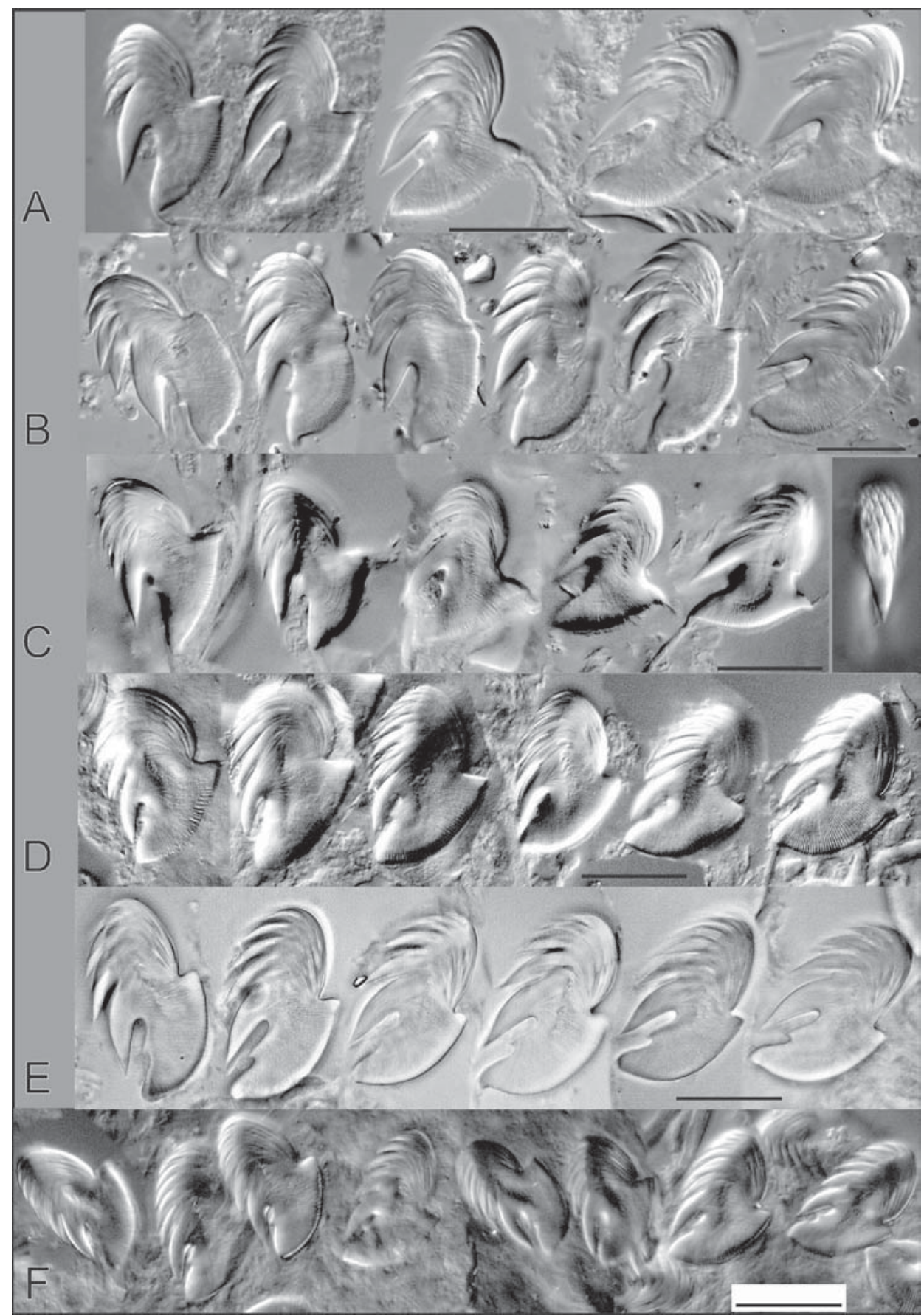

Fig. 5. Thoracic uncini of Amphitrite birulai Ssolowiew, 1899. TU1: A — ZIN6; B - ZIN3; C - Black river; D - APEM9533; E - BDUA 1372.02; TU7: F — APEM9533. Scale bars: $20 \mu \mathrm{m}$. Uncini of each row are combined from the single slide from specified neuropodium.

Рис. 5. Неврохеты Amphitrite birulai Ssolowiew, 1899. TU1: A - ZIN6; B - ZIN3; C - Чёрная река; D - APEM9533; E — BDUA 1372.02; TU7: F — APEM9533. Масштаб: 20 мкм. Фотографии неврохет каждого вида сделаны с одного препарата с указанной невроподии. 
whether the presence or absence of eyespots depends upon fixation, preservation or geographic variation.

6. Grainger (1954) reported A. affinis from $63^{\circ} 33^{\prime} \mathrm{N} 67^{\circ} 59^{\prime} \mathrm{W}$, intertidal. All characters mentioned agree with $A$. birulai.

DISTRIBUTION. From high Arctic to Iberian Atlantic, shelf depth, common in estuaries.

Amphitrite buzhinskaje Jirkov, sp.n. Figs 1I, 6, 7.

Neoamphitrite grayi - Annenkova, 1937: 192; 1938 : 206; Uschakov, 1955: 392; Buzhinkaja, 1967: 114 — non Malmgren, 1866.

HOLOTYPE $42^{\circ} 36^{\prime} \mathrm{N} 131^{\circ} 09^{\prime} \mathrm{E}, 2 \mathrm{~m}, 09$. 1981, deposited at DGEH KGB MGU-Pol-32

PARATYPES Sea of Japan: DGEH collection, Vostok Bay, 42 ${ }^{\circ} 54^{\prime} 34.7^{\prime \prime} \mathrm{N} 132^{\circ} 44^{\prime} 23.1^{\prime \prime}$ E, 2,5 m 29.07.2009, st.768 KGB MGU-Pol-33 (1 specimen); 42 $52^{\prime} 06.5^{\prime \prime} \mathrm{N} 132^{\circ} 41^{\prime} 05.0^{\prime \prime} \mathrm{E}, 8$ m, 8.09.2009, st.831 KGB MGU-Pol-34 (1 specimen); $42^{\circ} 52^{\prime} 06.5^{\prime \prime} \mathrm{N} 132^{\circ} 41^{\prime} 05.0^{\prime \prime}$ E, $7 \mathrm{~m}$,
8.09.2009, st. 838 KGB MGU-Pol-35 (2 specimens); Ussurijsky Bay, $43^{\circ} 01^{\prime} 15.6^{\prime \prime} \mathrm{N} 131^{\circ}$ 55'40.7" E, 8.10.2014 KGB MGU-Pol-36 (1 specimen); ZIN collection Olga Bay ZIN 1/ $32207,8 \mathrm{~m}, 43^{\circ} 44^{\prime} 40^{\prime \prime} \mathrm{N} 135^{\circ} 17^{\prime} 10^{\prime \prime} \mathrm{E}$, 22.07 .1932 (1 sp.); Expedition Bay ZIN 7

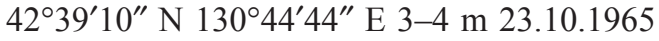
(5); ZIN 8, 5-6 m 21.10.1965; ZIN 10/36948 (2 sp.) (8); ZIN 11/36949 (1 specimen); ZIN 12162 m 27-28.05.65 (7 specimens), Vostok Bay ZIN 27/46992 (1 specimen); Yellow Sea: ZIN 2/10973 42 m 6.7.1958 (1 specimen); ZIN 3/ $1097451 \mathrm{~m} \mathrm{14.9.1957} \mathrm{(1);} \mathrm{ZIN} \mathrm{4/10975} 55 \mathrm{~m}$ 25.10.57 (2); ZIN 5/10976 54 m 27.7.1957 (1 specimen); ZIN 6/10977 55 m 25.10.1957 (1 specimen)

ETYMOLOGY. The species is named after Russian polychaetologist Dr. G.N. Buzhinskaja (Fig. 8).

DESCRIPTION (based on holotype and paratypes). Up to $100 \mathrm{~mm}$ in length, for about 60 segments. Eyespots absent. Branchiae arbores-

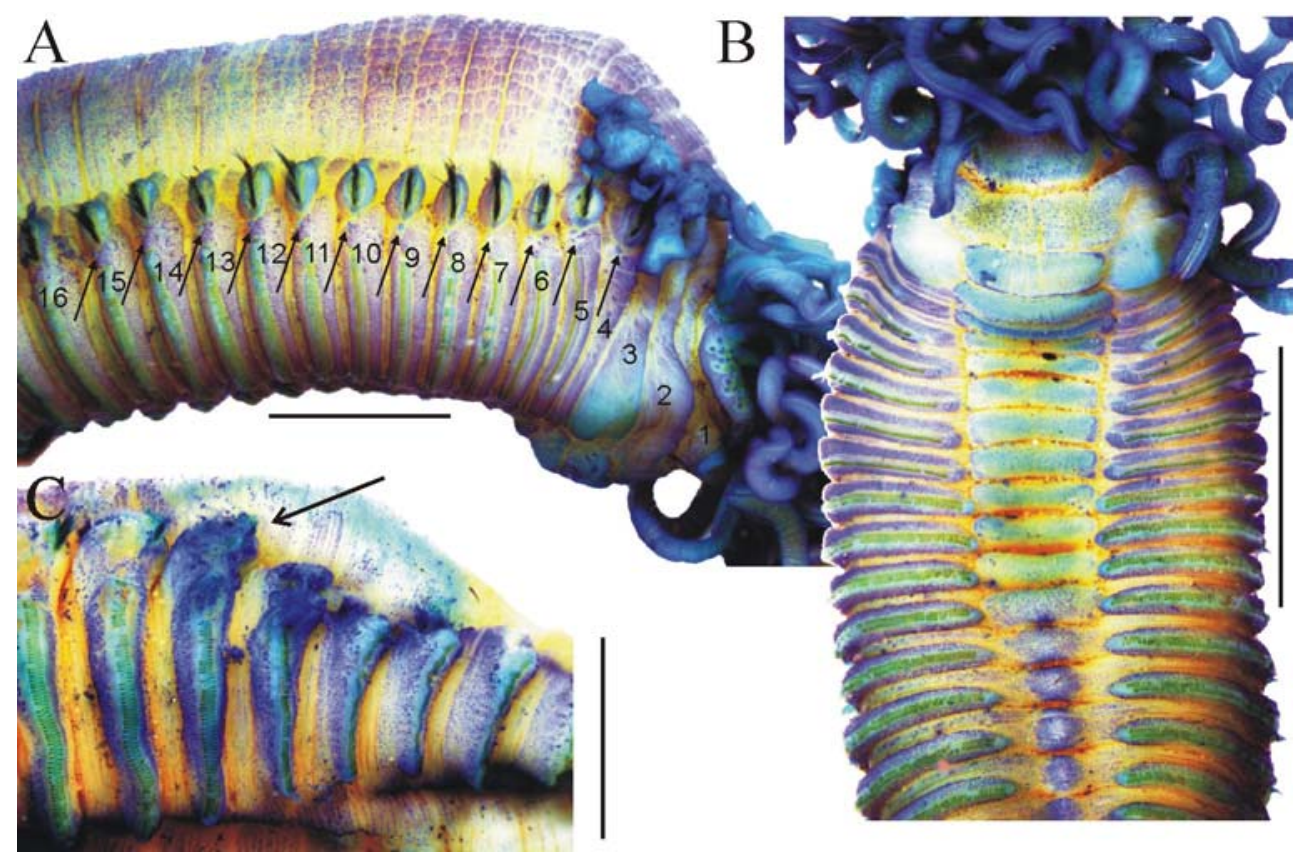

Fig. 6. Amphitrite buzhinskaje Jirkov, sp.n., external morphology. Holotype. A — lateral view; B — ventral view; C - thorax-abdomen border. Scale bars: A $-5 \mathrm{~mm}, \mathrm{~B}-2 \mathrm{~mm}, \mathrm{C}-1 \mathrm{~mm}$.

Рис. 6. Amphitrite buzhinskaje Jirkov, sp.n., внешняя морфология. Голотип. А — вид сбоку; В - вид с брюшной стороны; C - граница торакса и абдомена. Масштаб: А - 5 мм, В - 2 мм, С - 1 мм. 


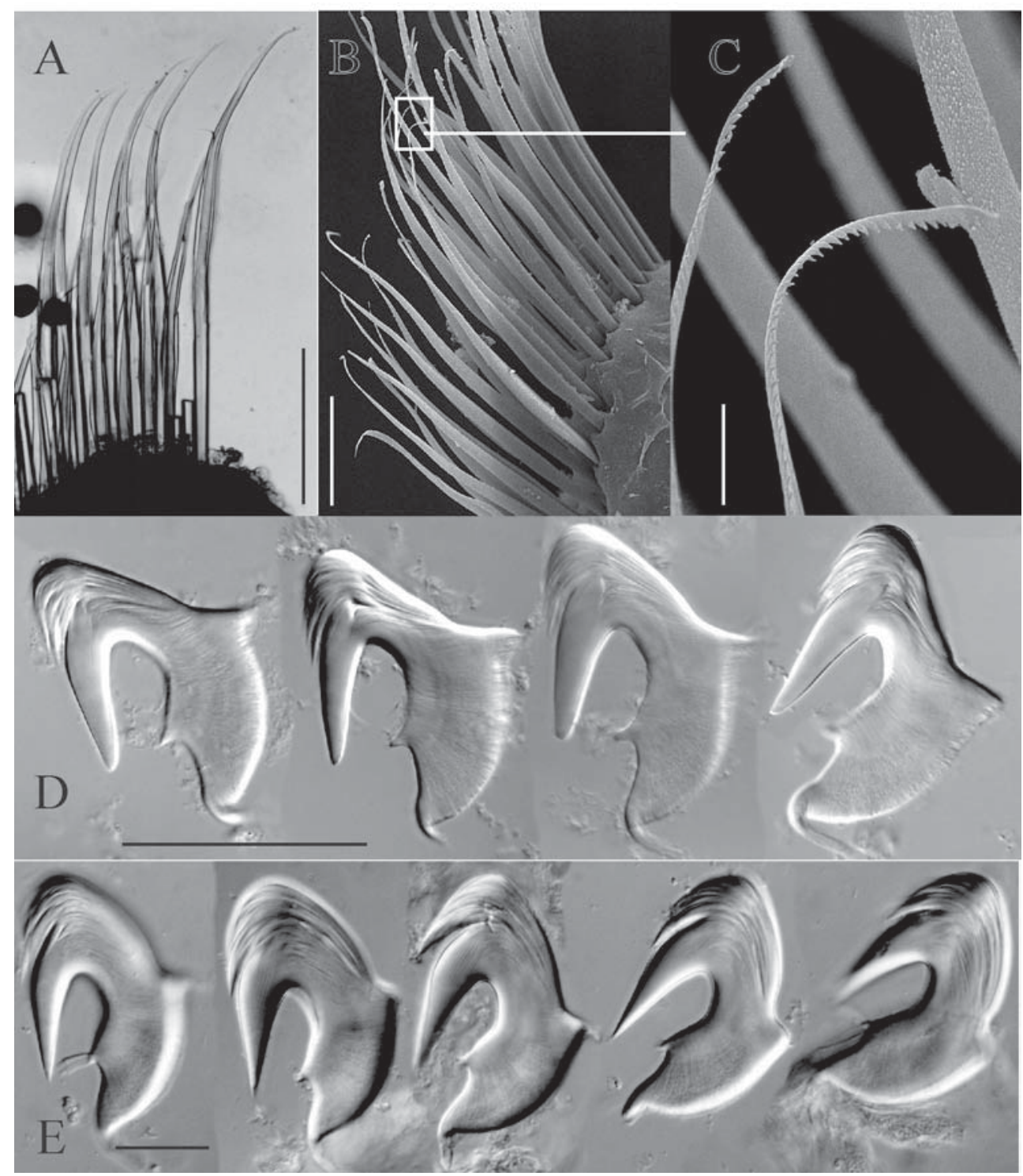

Fig. 7. Amphitrite buzhinskaje Jirkov, sp.n., chaetae. A-C - notochaetae TC5, holotype; B - notochaetae TC17, Vostok 838; C - details of B; D - uncini TU1, ZIN 12-16; E - uncini AU22, holotype. Scale bars: $\mathrm{A}-0.2 \mathrm{~mm}, \mathrm{~B}-0.1 \mathrm{~mm}, \mathrm{C}-10 \mu \mathrm{m}, \mathrm{D}-50 \mu \mathrm{m}, \mathrm{E}-20 \mu \mathrm{m}$.

Рис. 7. Amphitrite buzhinskaje Jirkov, sp.n., щетинки. A-C - нотохеты TC5, голотип, В - нотохеты TC17, Восток 838; C - детали B; D - uncini TU1, ZIN 12-16; E — uncini AU22, голотип. Масштаб: $\mathrm{A}-0,2$ мм, $\mathrm{B}-0,1$ мм, $\mathrm{C}-10$ мкм, $\mathrm{D}-50$ мкм, $\mathrm{E}-20$ мкм.

cent with long branches, all of same size. Lateral lobes: S2 as thickening of anterior margin, S3 small, upper margin at level of upper margin of uncinal row of TU1, reaching pad ventrally, slightly lower at mid-length than at ventral and dorsal margins; S4 small to inconspicuous below and in front of notopodia. Ventral pads smooth, well separated from neuropodia laterally, to TU10-TU11, narrower than longest thoracic uncinal row. Thirteen pairs of nephrid- 


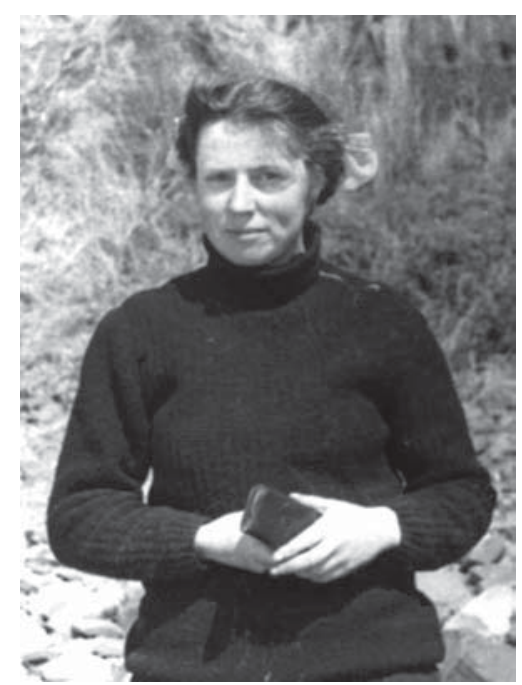

Fig. 8. Dr. Galina Nikolaevna Buzhinskaja. Рис. 8. Галина Николаевна Бужинская.

ial papillae (visible in 8 specimen): large, lateral to branchiae on S3, lateral to notopodia on S4, others between noto- and neuropodia, just posterior to uncinal row; all papillae of same size.

Notopodia from S4, present on 21 segments, seldom (two specimen from ZIN 7 and ZIN 8) on 22 segments, and in one case (st. 838) on 23 segments. Notochaetae of two types, both: long, narrow, symmetrically narrow bilimbate with serrated tips.

Neuropodia from S5, uncini facing forward, TU7-TU20 (last thoracic) with uncini in double rows (uncini face-to-face); if $22 \mathrm{TC}$, present, last thoracic neuropodia with single (ZIN 8) or double (ZIN 7) rows of uncini; rows not separated, uncini intercalar. All abdominal neuropodia with single rows of uncini. Thoracic and abdominal neuropodia of same shape, all tori. Thoracic neuropodia large, ventrally almost reaching pads, uncinal row of TU1 ventrally shorter than on TU2, of TU2 than on TU3. Uncinal rows and neuropodia of AU1 almost same size as those of last TC (19 ex., other poorly preserved). Avicular crest of uncini with numerous teeth in several rows; thoracic and abdominal uncini all similar.
REMARKS. 1. Five species of Amphitrite have 20-23 TC and three pairs of branchiae. Three of them: A. rubra (Risso, 1826), A. vigintipes Grube, 1870 (according to Marenzeller, 1884) and A. chloraema (Schmarda, 1861) (according to Ehlers, 1901) have uncini in double rows almost to the pygidium. Amphitrite pachyderma Hutchings et Glasby, 1988 has uncini in double rows to C39-C43. Of these, only $A$. grayi Malmgren, 1866, as $A$. buzhinskaje sp.n., has $21 \mathrm{TC}$ and all abdominal neuropodia with a single row of uncini. Amphitrite buzhinskaje sp.n. differs from $A$. grayi in that the neuropodia of AU1 are almost of the same size as those of the last TU (usually TU20), instead of two to three times shorter; A. buzhinskaje sp.n. has 1213 segments with nephridial papillae, while $A$. grayi has 10-11. Also, A. buzhinskaje sp.n. inhabits shallow waters (in the Sea of Japan less than $10 \mathrm{~m}$, in the Yellow Sea deeper, but still shallow), while A. grayi inhabits outer shelf depths, 20-500 m deep (Holthe, 1986, our data).

2. Paratypes from the ZIN collection, had been previously identified as Neoamphitrite grayi by Annenkova (1937, 1938), Buzhinskaja (1967) and Wu Bao-Ling (unpublished).

DISTRIBUTION. Probably low boreal and subtropical west Pacific species. I expect it to be found at shallow depths further south, above the tidal front (upper sublittoral).

\section{Amphitrite cirrata Müller, 1776 \\ Figs 1A, E, 2A, 9, 10.}

Amphitrite cirrata Müller, 1776: 216; Malmgren, 1866: 375, tab. XXI, fig. 53; Fauvel, 1927: 251-252, fig. 86 i-o (partim); Zatsepin, 1948: 156, table XXXVIII, 12 (partim); Hartmann-Schröder, 1971: 471-472, Abb. 163; 1996: 506-507; Abb. 245; Holthe, 1986: 96-98, fig. 40, map 39; Jirkov, 1989: 126-127, Fig. 25.3 (partim); 2001: 509-510 (partim) - non Uschakov, 1955: 392, Fig. 1473.

? Nereis cirrosa Linnaeus, 1767: 1085 - nomen dubium.

MATERIAL EXAMINED. 42 samples (125 specimens) from DGEH collection (Appendix), 6-24 m.

DESCRIPTION. Up to $200 \mathrm{~mm}$ in length. Eyespots absent. Branchiae usually as numerous simple filaments, arising from a very short stem, sometimes stem absent and filaments aris- 


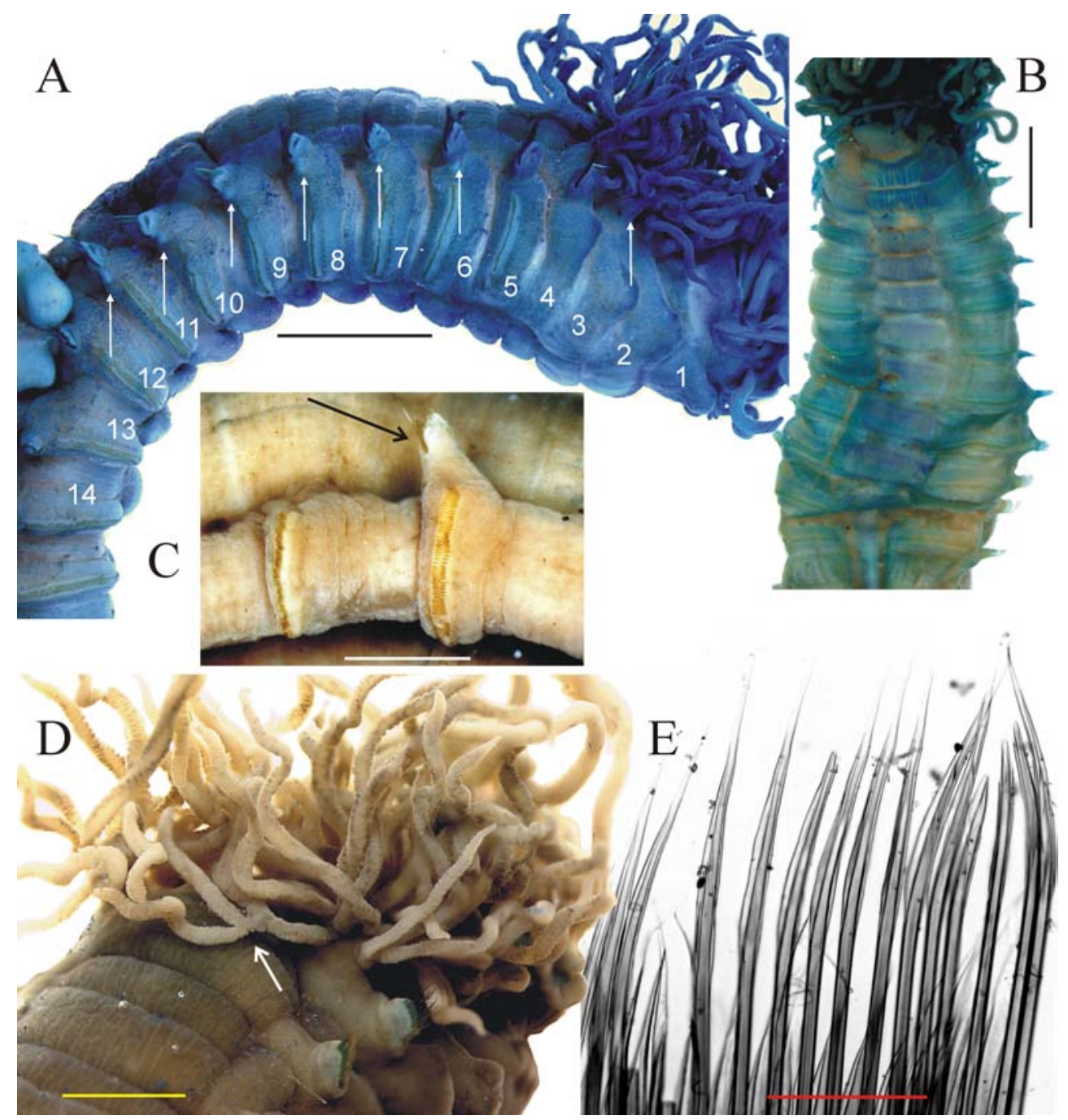

Fig. 9. Amphitrite cirrata Müller, 1776, external morphology. A — lateral view, WSBS; B — ventral view, WSBS; C - thorax-abdomen border, last notopodia arrowed, WSBS; D — branchia, branching arrowed, WSBS; E - notochaetae, WSBS. Scale bars: A, B $-2 \mathrm{~mm}, \mathrm{C}, \mathrm{D}-1 \mathrm{~mm}, \mathrm{E}-0.2 \mathrm{~mm}$.

Рис. 9. Amphitrite cirrata Müller, 1776, внешняя морфология. А - вид сбоку, ББС; В - вид с брюшной стороны, ББС; C - граница торакса и абдомена, ББС; D - жабра, место ветвления показано стрелкой, Persey 1271; Е - нотохеты, ББС. Масштаб: A, B - 2 мм, C, D - 1 мм, E - 0,2 мм.

ing directly from body wall (12 of 97 examined worms); very rarely, some filaments branched ( 7 of 97 examined worms). S1 forms collar ventrally. Lobes of S2-S4 distinct, lateral: dorsaly with semicircular lobes, gradually placed dorsally from S2 to S4, S2 additionally with lobe ventrally. Ventral pads up to TU8-TU12, some anteriorly wrinkled. Seven pairs of nephridial papillae: one pair lateral to second branchiae (on S3) very large, almost half size of notopodia of TC1; six much smaller pairs between notoand neuropodia of S6-S11 (first segment with double row of uncini), S4 and S5 without papillae.

Notopodia from S4, present on 17 segments. Notochaetae with serrated tips, of two types 

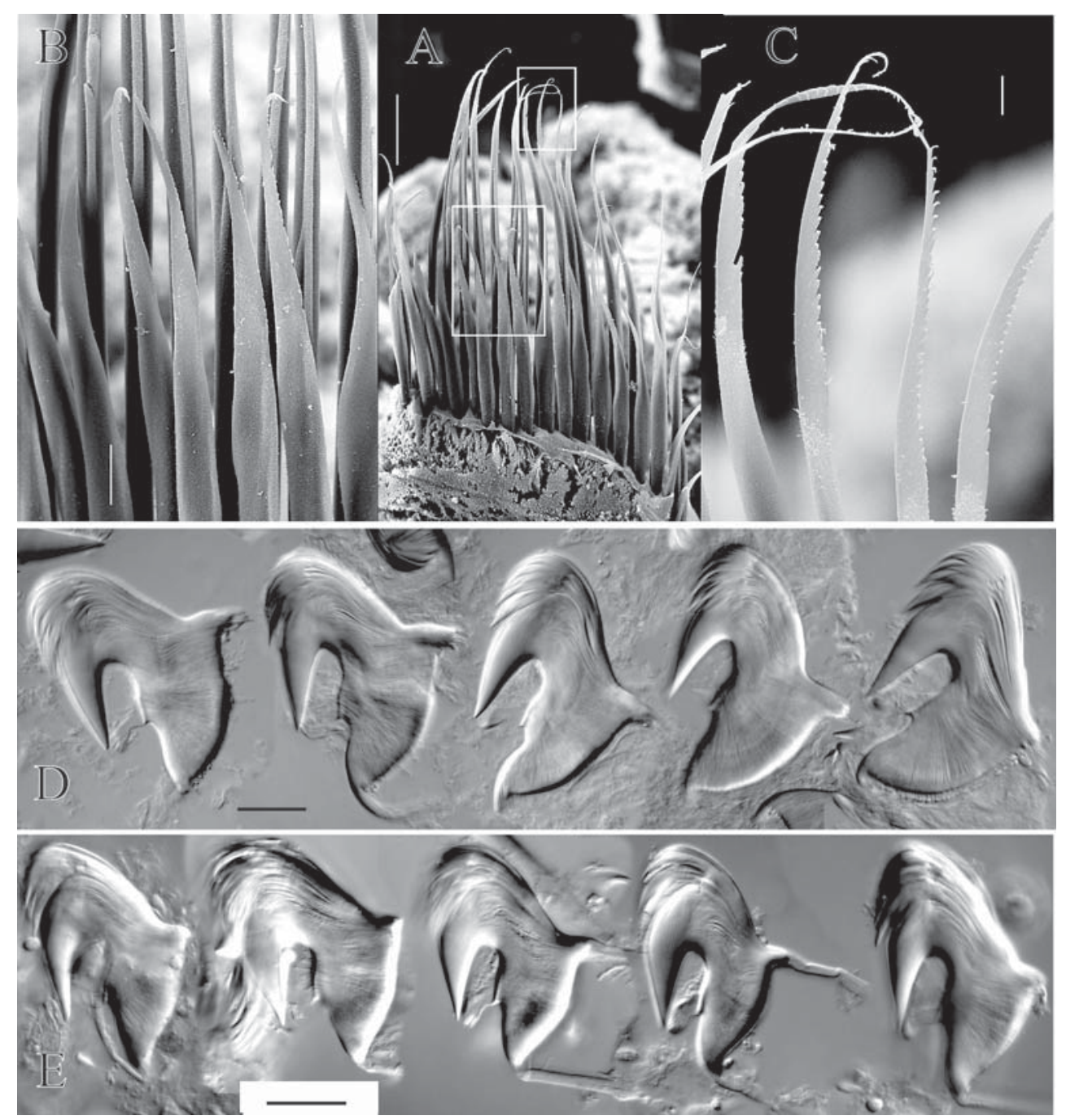

Fig. 10. Amphitrite cirrata Müller, 1776, chaetae. A-C - notochaetae Black river; B, C - details of A; D, $\mathrm{E}$ - uncini TU1; D - Ermolinskaja 77; E - uncini AU30 WSBS. Scale bars: A $-0.1 \mathrm{~mm}, \mathrm{~B}-30 \mu \mathrm{m}$, $\mathrm{C}-10 \mu \mathrm{m}, \mathrm{D}-\mathrm{E}-20 \mu \mathrm{m}$.

Рис. 10. Amphitrite cirrata Müller, 1776, щетинки. А-C - нотохеты, Чёрная речка; В, C - детали А; D, E - uncini TU1; D - Ермолинская 77; E - uncini AU30, ББС. Масштаб: A - 0,1 мм, B - 30 мкм, $\mathrm{C}-10$ мкм, D-F - 20 мкм.

(longer and shorter), both slightly unequally bilimbate (keeled), with serrated tips.

Neuropodia (uncini face forwards) from C2. Uncini in double rows (uncini face-to-face, rows adjacent to each other) on TU7-TU16 (end of thorax), all abdominal uncini in single rows (uncini facing forwards). All neuropodia large; first nine neuropodia reaching ventral pads; pads progressively less conspicuous posteriorly, with gap to neuropodia. All neuropodia tori; no abrupt change in size of neuropodia from thorax to abdomen. Uncini avicular; thoracic and abdominal uncini all similar. Tube muddy, thickness of tube wall several times less than inner diameter.

REMARKS. 1. The first pair of nephridial 
pailllae (near second pair of branchiae) is visible on worms $1 \mathrm{~cm}$ long and less than $1 \mathrm{~mm}$ wide, but the last six papillae are not visible in worms of that size, even after staining, and sometimes they are hardly visible without staining in larger worms. Probably, these papillae are present in sexually mature worms only. One specimen (SChS-2032 st. 381) has additional papillae on S12 (eight pairs of papillae in total); other specimens from the same sample have the typical seven pairs of papillae.

2. Müller's (1776) description is very short: “cincinnis utrinque tribus", meaning "curls three sides", i.e. three pairs of branchiae, which fits most European Amphitrite, all Eupolymnia and Terebella. The species is understood here as described later by Malmgren (1866) and Fauvel (1927). Müller (1771) disscussed usage of the name Spio cirrata by König but gave no citation or even date for the König publication); however, as there was no description, Amphitrite cirrata Müller, 1771 is nomen nudum, and 1771 cannot be the year of publication. The concept of Spio cirrata König is unclear and, besides, as it was published before Systema Naturae, should not be accepted (ICZN, Art. 3.2). Nereis cirrosa L, is mentioned as a senior synonym by Read \& Fauchald (2020h), as Müller (1771, 1776) refers to Nereis cirrosa L, probably as its synonym, but it is not clear; also, Linnaeus (1771) did not provide a reasonable description, so this name should be treated as nomen dubium.

3. Description given above based on shallow water (upper sublittoral) specimens of boreal regions. Preparing these paper to be published I found that more Arctic and deeper worms (94 specimens from 32 stations from DGEH and IO RAN collections, 23-295 m) belong to quite different species (Fig. 11). This species differs from upper sublittoral by the comparative size of AU1 and TU last neuropodia. Upper sublittoral species has AU1 neuropodia equal to neuropodia of last TU (Fig. 9D), while low sublittoral species has AU1 neuropodia about half size of last TU neuropodia (Fig. 11D). All other charater of these species are similar. One specimen (Maslov st.226) has 19 notopodia and corresponding number of double rows neuropodia, while on the other had 17 notopodia and corresponding number of double rows neuropodia. Unfortunately COVID-19 does not allows me to investigate ZIN collection and other collections outside Moscow, so distribution of these two species based on DGEH and IO RAN collections only. I do not described the new species and named it here as Amphitrite aff. cirrata because I have no specimens from the type locality. $\mathrm{Gu}$ mundur $\mathrm{Gu}$ mundsson in his letter to me wrote that "a couple of years ago the late Gudmundur Vidir Helgason, searched the collection of IINH and he did not find any ethanol nor formalin fixed specimens of Amphitrite cirrata". Original description is too brief to choose between these two species, so I cannot be absolutely sure that I am right thinking that upper sublittoral boreal species is A. cirrata s.str., but it is highly likely.

DISTRIBUTION. The type locality of Amphitrite cirrata was not stated in the original description at all but, judging by its title ("Animalium Daniae et Norvegiae indigenarum" = native animals of Norway and Denmark), it should be one of these countries. According to Hartman (1959), the type locality is Iceland. This seems strange today, as Iceland is neither Denmark nor Norway but, in 1776, Denmark, Norway and Iceland were a single country, so it does not contradict Müller's title. Norwegian polychaetologist Holthe (1986) also cited the type locality as Iceland. However, later Read, Fauchald (2020i) changed the type locality to "United Kingdom Exclusive Economic Zone", which cannot be accepted. Holthe (1986) investigated material from Scandinavian waters and Iceland. It is highly probable that the species does occur in Greenland and temperate North American waters.

Unlikely reports. Fauvel (1927) reported the species from the Azores, Morocco, and Mediterranean, as well as the Arctic and temperate Atlantic. Although he described 7 pairs of nephridial papillae in true segments, I doubt that this relates to worms from these regions. I did not find A. cirrata amongst worms investigated from the Mediterranean, Azores, Atlantic coast of the Iberian Peninsula or even the UK but, instead, found two other Amphitrite species 

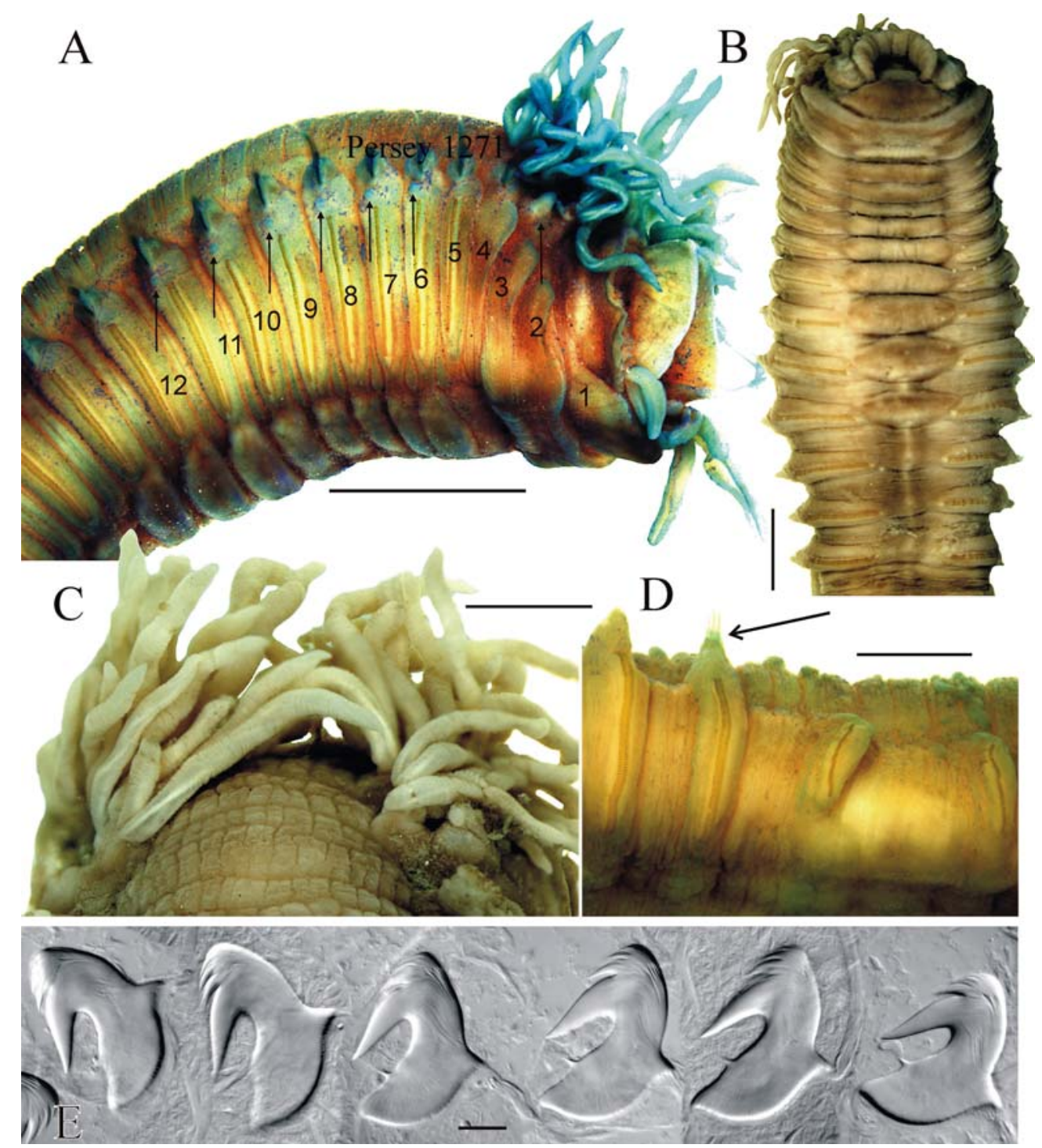

Fig. 11. Amphtrite aff. cirrata. A - lateral view, Persey 1271; B - ventral view, Persey 1270; C branchiae, Persey 1270; D - thorax-abdomen border, last notopodia arrowed, Persey 1271; E - uncini TU1, Persey 1271. Scale bars: A, B $-2 \mathrm{~mm}, \mathrm{C}, \mathrm{D}-1 \mathrm{~mm}, \mathrm{E}-20 \mathrm{мm}$.

Fig. 11. Amphtrite aff. cirrata. А - вид сбоку, Персей 1271; В - вид с брюшной стороны, Персей 1270; C - жабры, Персей $1270 ; \mathrm{D}$ - граница торакса и абдомена, последняя нотоподия показана стрелкой, Персей 1271; Е — неврохеты TU1, Персей 1271. Масштаб: А, В - 2 мм, С, D - 1 мм, E - 20 мкм.

with cirriform branchiae, both with four pairs of nephridial papillae: A. rzhavskyi sp.n. in shallow water, A. fauveli in deep water. Reports from Arctic probably belong to $A$. aff. cirrata, at least $A$. cirrata s.str. strictly limited to boreal upper sublittoral.
All investigated specimens from Pacific belong to Amphitrite aff. cirrata, so I suppose that other Pacific data (Uschakov, 1955; Imajima \& Hartman, 1964, Hobson, Banse, 1981) belong to this species instead of Amphitrite cirrata s.str. 
Worms reported as $A$. cirrata from California have "nephridia in setigers 3 to 5 " (Hartman, 1969: 583), while A. cirrata s.str. has no papillae on S4 or S5. Also, Hartman (1969: 583) wrote: "Thoracic uncini... in double rows from setiger 7"; this is most probably a lapsus calami (should be from C8). Although the segment at which uncini in double rows begin is very stable in Terebellini and Artacamini (Jirkov, 2001), some variation may occur. For Axionice elongata, an even earlier begining was reported (Jirkov, Leontovich, 2017), so Hartman's report could also describe a variation in the character of worms from California. Hartman's material obviously needs to be re-examined and perhaps belongs to a new, undescribed species.

Day (1967) reported the species from the Cape of Good Hope and Senegal; this seems very doubtful, judging from the verified distribution (perhaps he had at hand A. rzhavskyi sp.n., described below); Holthe (1986) excluded Senegal and the Cape of Good Hope from its range. Day, like Hartman (1969), reported "thoracic uncini from segment 5 and arranged in two rows from setiger 7 to 16" (Day, 1967: 747). As with Californian worms, it is either lapsus calami or variation, or the character of worms from South Africa.

A. cirrata profunda Fauvel, 1909 is a nomen nudum, probably the same as A. fauveli (Jirkov et al., 2018).

Amphitrite edwardsii (Quatrefages, 1866)

Figs 12, 13.

Terebella edwardsii Quatrefages, 1866: 354. $84 \mathrm{a}-\mathrm{i}$.

Amphitrite edwardsi — Fauvel, 1927: 245-246, Fig.

MATERIAL EXAMINED. APEM 39607 (1 sp.) (Belfast Lough), APEM 36707 (1 sp.) (Orkney); BDUA DBVA0000591 38 38'-

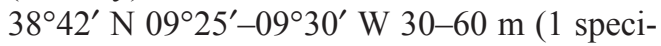
men).

DESCRIPTION. Up to $50 \mathrm{~mm}$ in length. Eyespots absent. Branchiae arborescent, stem more or less flattened, little or no difference in size between first and third branchiae. Lateral lobes on S2-S4 distinct, S2 ventro-lateral, S3 almost not extending onto ventrum, distinctly dorsal to S2 lobes, S4 at level of notopodia; all lobes of similar size. Ventral pads smooth, wellseparated from neuropodia, last pad on TU9. Nine pairs of almost equal-sized nephridial papillae, on S3-S11; lateral to branchiae on S3; lateral and slightly posterior to notopodia on $\mathrm{S} 4$; between notopodia and neuropoida on S5-S11, at posterior margin of neuropodia.

Notopodia from S4, present on 17 segments. Notochaetae of two types (longer and shorter), both narrow, symmetrically bilimbate with serrated tips.

Neuropodia (uncini facing forward) from S5, uncini in double rows (face-to-face) on TU7-TU16, rows well separated; all abdominal neuropodia with uncini in single rows. Rows of uncini distinctly shorter on TU1 than on TU3. Rows of uncini on AU1 half size of last TU. Thoracic and abdominal neuropodia tori, becoming more pinnuli-like posteriorly, but uncini still far from margin (real pinnuli have uncini on the edge). Uncini avicular, thoracic and abdominal uncini all similar.

REMARKS. 1. The original description is not informative. The species concept accepted here follows Fauvel (1927).

2. Fauvel (1927) reported length up to 150 $\mathrm{mm}$.

DISTRIBUTION. Western Europe (type locality St. Vaast, Channel, France) from Scotland to southern Portugal.

Unlikely reports. Also, reported from the Falkland Islands (Monro, 1930), Japan (Imajima \& Hartman, 1964), British Columbia and Washington (Banse, Hobson, 1968; Hobson, Banse, 1981). All these reports need confirmation. The true range of $A$. edwardsii s.str. is probably limited to southern boreal European waters, as with $A$. grayi (Atlantic species) and $A$. buzhinskaje (Pacific species), clarified here. Specimens from the Falkland Islands [judging from Monro's (1930) description] have 10 instead 9 nephridial papillae and uncini with distinctly shorter main teeth. Reports from the Mediterranean are probably due to the misidentification of $A$. variabilis, as I have not found $A$. edwardsii in my examined material, while $A$. variabilis is abundant (see below). 


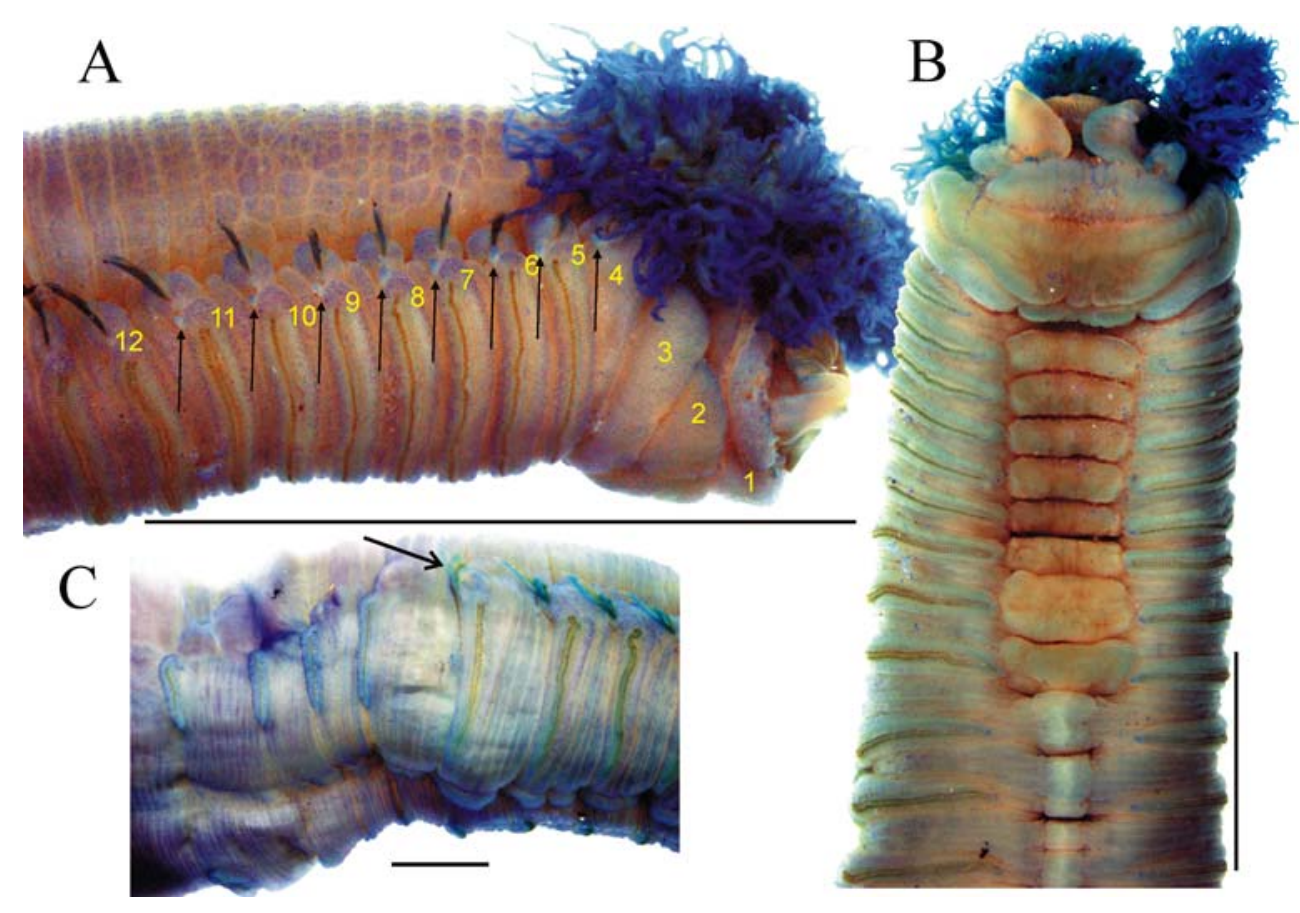

Fig. 12. Amphitrite edwardsii (Quatrefages, 1866), external morphology. A — lateral view APEM 7172; B ventral view, APEM 004088; C - thorax-abdomen border, APEM 004088. Scale bars: A $-5 \mathrm{~mm}$, B $2 \mathrm{~mm}, \mathrm{C}-1 \mathrm{~mm}$.

Рис. 12. Amphitrite edwardsii (Quatrefages, 1866), внешняя морфология. А — вид сбоку, АРЕМ 7172; В - вид с брюшной стороны АРЕМ 004088; С — граница торакса и абдомена, АРЕМ 004088. Масштаб: А -5 мм, $\mathrm{B}-2$ мм, $\mathrm{C}-1$ мм.

Amphitrite figulus (Dalyell, 1853)

Figs 1C, 14, 15.

Terebella figulus Dalyell, 1853: 191-197 Pl. XXVII 1, 2, P1.XXVIII 1, 2.

Amphitrite figulus - Hartmann-Schröder, 1971: 473475, Abb. 164; Jirkov, 2001: 511.

Neoamphitrite figulus - Zatsepin, 1948: 157, table XXXVIII, 15; Uschakov, 1955: 392; Holthe, 1986: 100101, fig. 42, map 41; Hartmann-Schröder, 1996: 515-516, Abb. 251.

Amphitrite johnstoni - Malmgren, 1866: 377, tab. XXI, fig. 56; Fauvel, 1927: 248-249, fig. 85a-e.

MATERIAL EXAMINED. 40 samples, 58 specimens, 1-48 m (Appendix).

DESCRIPTION. Up to $250 \mathrm{~mm}$ length. Eyespots absent. Branchiae arborescent, with thick stem and long branches, first branchiae twice size of branchiae of third ones. Lateral lobes of S2 and S3 distinct; higher on S3 than S2; small or inconspicuous on S4. About 14 ventral pads.
Nephridial papillae very small and difficult to count, even after staining, especially in small worms, present at least on segments $3-18$, progressively shorter.

Notopodia from S4, present on 23-27 segments. Notochaetae of two types (longer and shorter), both narrow, symmetrically bilimbate with serrated tips.

Neuropodia from S5, facing forwards, uncini in double rows from C8 to C23-S29 (uncini face-to-face), i.e. at least one abdominal neuropodium with uncini in double row; rows well separated; all neuropodia tori, no abrupt change in size or shape of neuropodia, either from thorax to abdomen, or at transition from neuropodia with double rows of uncini to those with a single row. Uncini avicular, crest with numerous teeth in several rows; thoracic and abdominal uncini all similar. 


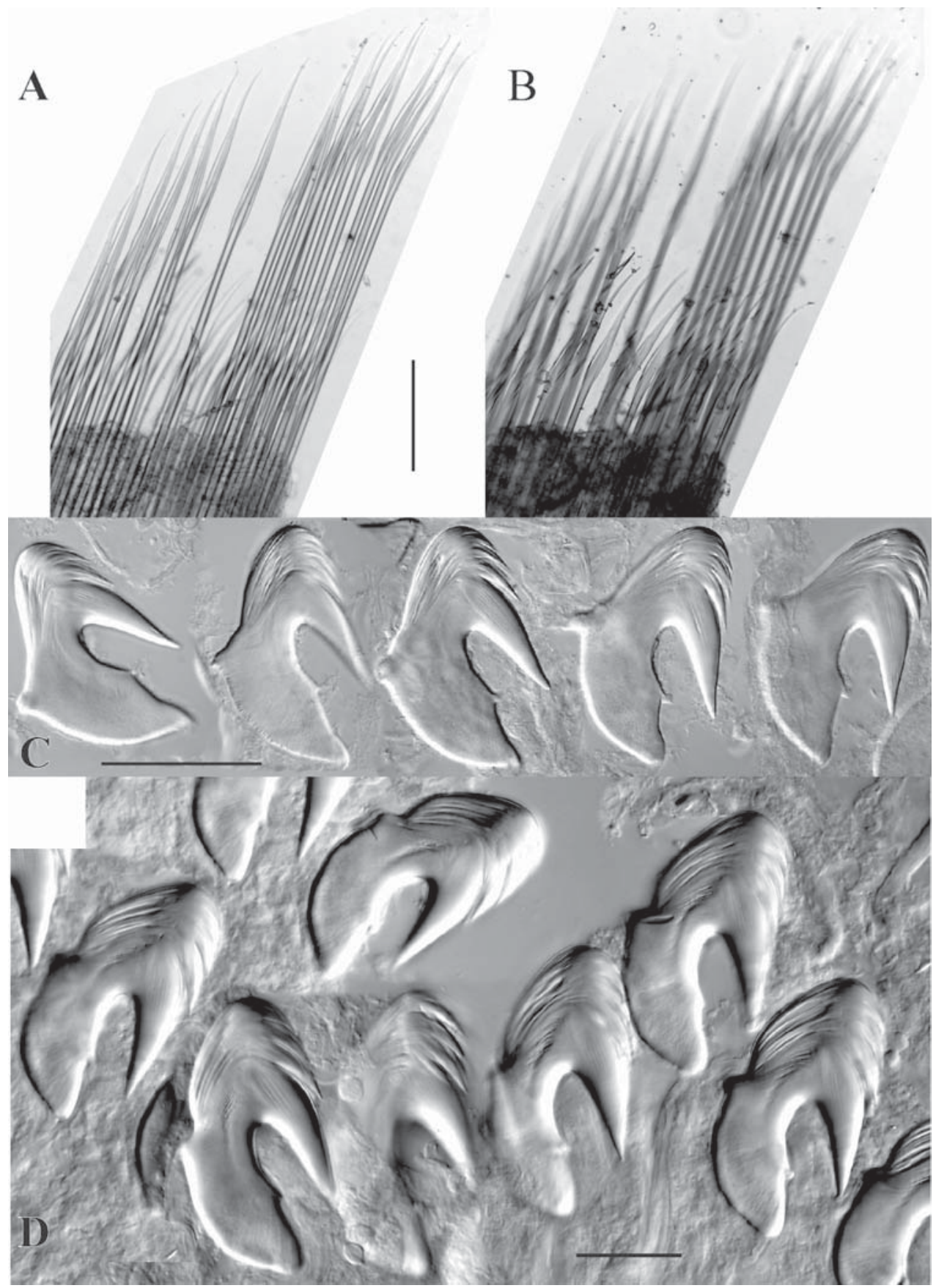

Fig. 13. Amphitrite edwardsii (Quatrefages, 1866), chaetae. A, B - notochaetae TC14, APEM 004088, different optical slices; C — uncini TU1, APEM 004088; D — uncini AU11, APEM 004088. Scale bars: $\mathrm{A}-0.2 \mathrm{~mm}, \mathrm{C}-50 \mu \mathrm{m}, \mathrm{D}-20 \mu \mathrm{m}$.

Рис. 13. Amphitrite edwardsii (Quatrefages, 1866), щетинки. А, В - нотохеты TC14, APEM 004088, различные оптические срезы; C - uncini TU1, APEM 004088; D - uncini AU11, APEM 004088. Масштаб: A - 0,2 мм, $\mathrm{C}-50$ мкм, D - 20 мкм. 


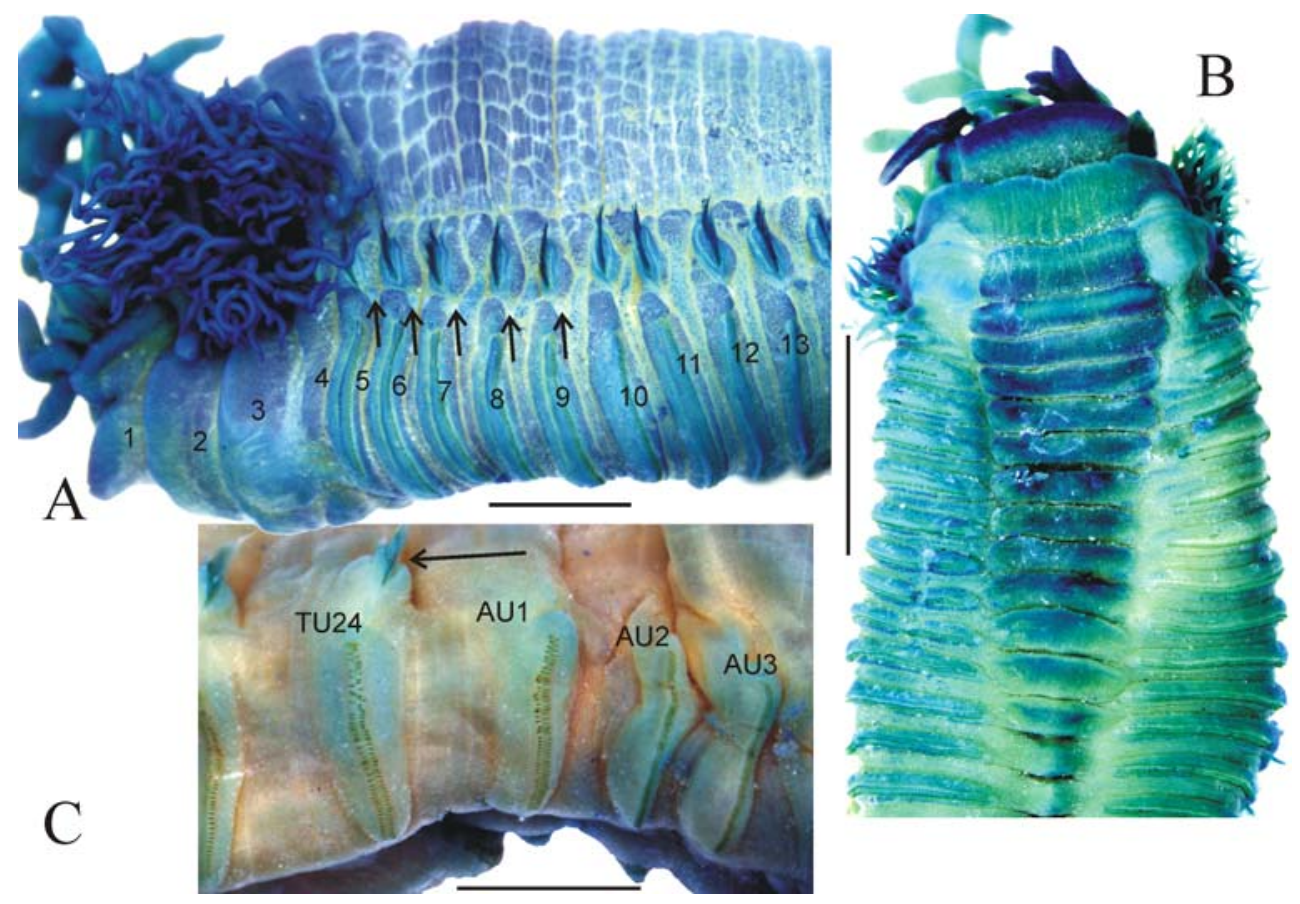

Fig. 14. Amphitrite figulus (Dalyell, 1853), external morphology. A - lateral view, WSBS; B — ventral view, Nilma 77; $\mathrm{C}$ - thorax-abdomen border Black river scale bar: $1 \mathrm{~mm}$. A, C $-1 \mathrm{~mm}, \mathrm{~B}-2 \mathrm{~mm}$. Рис. 14. Amphitrite figulus (Dalyell, 1853), внешняя морфология. А - вид сбоку, ББС; В - вид с брюшной стороны, Нильма 77; C - граница торакса и абдомена, Чёрная речка. Масштаб: A, C - 1 мм, В - 2 мм.

REMARKS. Amphitrite johnstoni has been accepted as a junior synonym of $A$. figulus since McIntosh (1875). Although McIntosh did not explain the reasons for the synonymy, comparison of both original descriptions and consideration of the proximity in the type localities (Great Britain for Terebella figulus; Sweden Bohuslän and Koster, 5-9 m deep, southern Norway and Britain for Amphitrite johnstoni), the synonymy seems adequate.

DISTRIBUTION. Boreal Atlantic from the White Sea to the UK. Western Pacific from Shantar Isl. (Sea of Okhotsk) to Peter the Great Bay (Sea of Japan). Above tidal front (upper sublittoral).

Unlikely reports. Often reported from the Mediterranean, but A. figulus was absent in the material I examined from the Mediterranean, while the very similar $A$. rubra was abundant. So, perhaps Mediterranean reports are based on misidentifications.
Amphitrite gracilis (Grube, 1860)

Figs 2B, 16, 17.

Amphitritides gracilis - Hartmann-Schröder, 1971: 476; 1996: 507-508, Abb. 246; Holthe, 1986: 104-106, fig. 45, map. 44; Jirkov, 2001: 512.

MATERIAL EXAMINED. 4 samples $(>125$ specimens) from DGEH collection: $43^{\circ} 06^{\prime} \mathrm{N}$ $40^{\circ} 37^{\prime} \mathrm{E}(23), 26.4 .2011 ; 45^{\circ} 48^{\prime} \mathrm{N} 32^{\circ} 37^{\prime} \mathrm{E}$, 08.1982 (>100 specimens); UK (Lundy, Bristol Channel): APEM 1224 (1 specimen) and APEM 1178 (1 specimen).

DESCRIPTION. Rather small Amphitrite, up to $20 \mathrm{~mm}$ in length. Eyespots absent. Two pairs of arborescent branchiae, branched two or three times, first branchiae larger than second ones. Lateral lobes indistinct. About ten smooth, well-separated ventral pads, pad width not exceeding length of tori. Nephridial papillae: large pair lateral to second branchiae (on S3); S4 and $\mathrm{S} 5$ without papillae; variable number from $\mathrm{S} 6$ : 

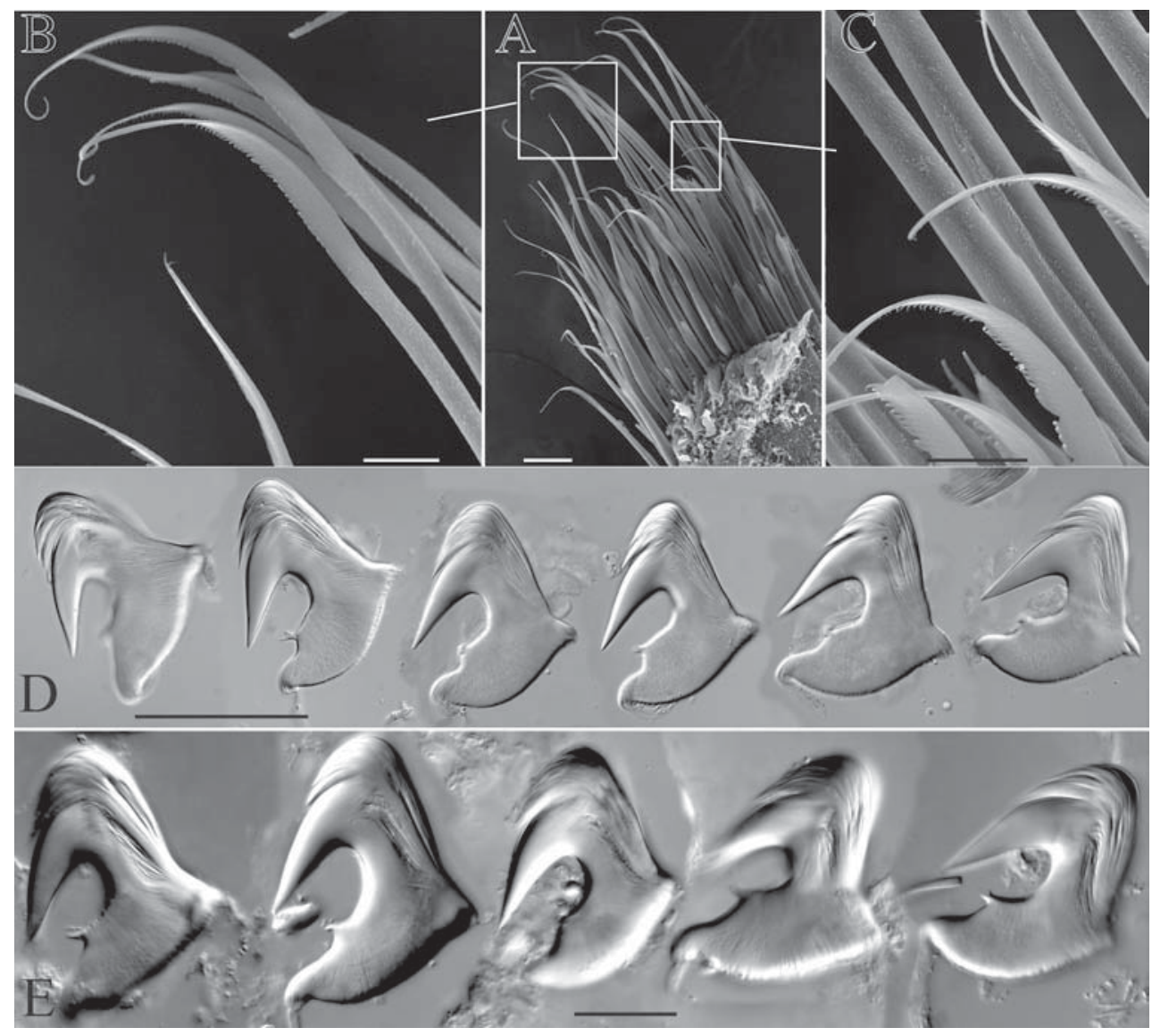

Fig. 15. Amphitrite figulus (Dalyell, 1853), chaetae. A-C — notochaetae, Ermolinskaja Bay, 1984: B, Cdetails of A; D - uncini TU1, Nilma, 1977; E - uncini AU4, Nilma, 1977. Scale bars: A - $0.1 \mathrm{~mm}$, B, $\mathrm{C}-30 \mu \mathrm{m}, \mathrm{D}-50 \mu \mathrm{m}, \mathrm{E}-20 \mu \mathrm{m}$.

Рис. 15. Amphitrite figulus (Dalyell, 1853), щетинки. A-C - нотохеты, Ермолинская губа, 1984: В, Сдетали A; D — uncini TU1, Нильма, 1977; E — uncini AU4, Нильма, 1977. Масштаб: А — 0,1 мм, В, $\mathrm{C}-30$ мкм, $\mathrm{D}-50$ мкм, $\mathrm{E}-20$ мкм.

six in topotypes, seven in material from the Black Sea.

Notopodia from S4, present on 17-19 segments. Notochaetae of two types: long and short, symmetrically wide, bilimbate, with base of blade sharper and wider than in other species investigated here with serrated tips.

Neuropodia from S5, all neuropodia tori; no abrupt change in size or shape of neuropodia from thorax to abdomen. Uncini facing forward, in double rows (uncini face-to-face), from TU7 almost to pygidium, rows well separated. Uncini avicular, crest with numerous teeth in several rows; thoracic and abdominal uncini all similar.
REMARKS. 1. The variation in the distribution of nephridial papillae is also known from the literature: eight segments in the type (Holthe, 1986), or nine, according to Fauvel (1927). It is not yet possible to decide whether this variation reflects geographic variation only or if there are different species, due to the lack of the material between the type locality (Scilly Is.) and the Black Sea, and the absence of DNA data.

2. McIntosh (1922) considered this species to be a junior synonym of $A$. scylla (Savigny, 1822). However all that is known from the original description of that species is that its members have 19 TC. So, the lack of detailed 


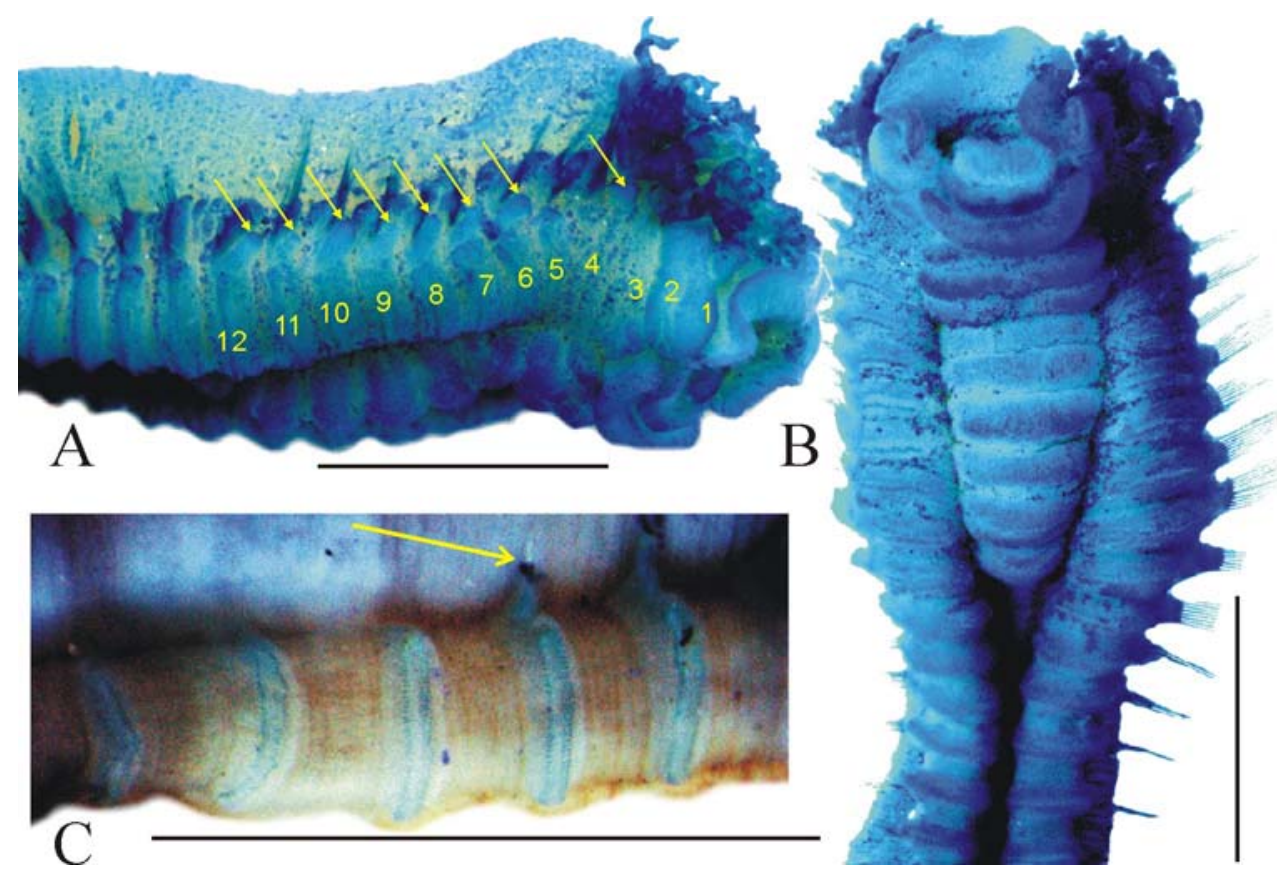

Fig. 16. Amphitrite gracilis (Grube, 1860), external morphology. A — lateral view, Gudauta; B — ventral view, Gudauta; C - thorax-abdomen border APEM. All scale bars: $1 \mathrm{~mm}$.

Рис. 16. Amphitrite gracilis (Grube, 1860), внешняя морфология. А — вид сбоку, Гудаута; В — вид с брюшной стороны, Гудаута; C — граница торакса и абдомена АРЕМ. Масштаб: 1 мм.

information forces us to consider A. scylla as nomen dubium.

DISTRIBUTION. East boreal Atlantic, from the Black Sea and Mediterranean and to northern Scotland. Probably upper sublittoral.

\section{Amphitrite grayi Malmgren, 1866} Fig. 18.

Amphitrite grayi Malmgren, 1866: 377, tab. XXII, fig. 56; Hartmann-Schröder, 1971: 473-474; Jirkov, 1989: 127, Fig. 25.2; 2001: 511.

Neoamphitrite grayi - Zatsepin, 1948: 157, table XXXVIII, 16; Holthe, 1986: 101-103, fig. 43, map 42; Hartmann-Schröder, 1996: 516 - non Annenkova, 1937: 192; 1938: 206; Uschakov, 1955: 392; Buzhinkaja, 1967: 114 (=Amphitrite buzhinskaje sp.n. see above).

MATERIAL EXAMINED. 5 samples (5 specimens) 245-445 m (Appendix).

DESCRIPTION. All investigated specimens are incomplete; estimated length of complete specimen at least $50 \mathrm{~mm}$, judging from size of available fragments, proportions of thorax and abdomen, and widths and lengths of members of other species of Amphitrite. Eyespots absent. Branchiae arborescent with long branches. Lateral lobes: thickening of anterior margin for S2; small, with upper margin at level of upper third of uncinal row of TU1 on S3, ventrally reaching pad, slightly lower at mid-length; small to inconspicuous below and in front of notopodia on S4. Ventral pads smooth, well separated from neuropodia laterally; after TU7 (first with uncini in double row), pads less conspicuous. Ten or eleven pairs of nephridial papillae: large, lateral to branchiae on S3; lateral to notopodia on S4; between noto- and neuropodia from S5 to S12$\mathrm{S} 13$, on posterior margins of neuropodia.

Notopodia from S4, present on 21 segments. Notochaetae of two types: long and short, both bilimbate with serrated tips.

Neuropodia from S5, uncini facing forwards, TU7-TU20 (last thoracic) with uncini in double rows (face-to-face); rows well separated. Thoracic neuropodia large, ventrally almost reaching pads; on TU1 and TU2, ventrally shorter 

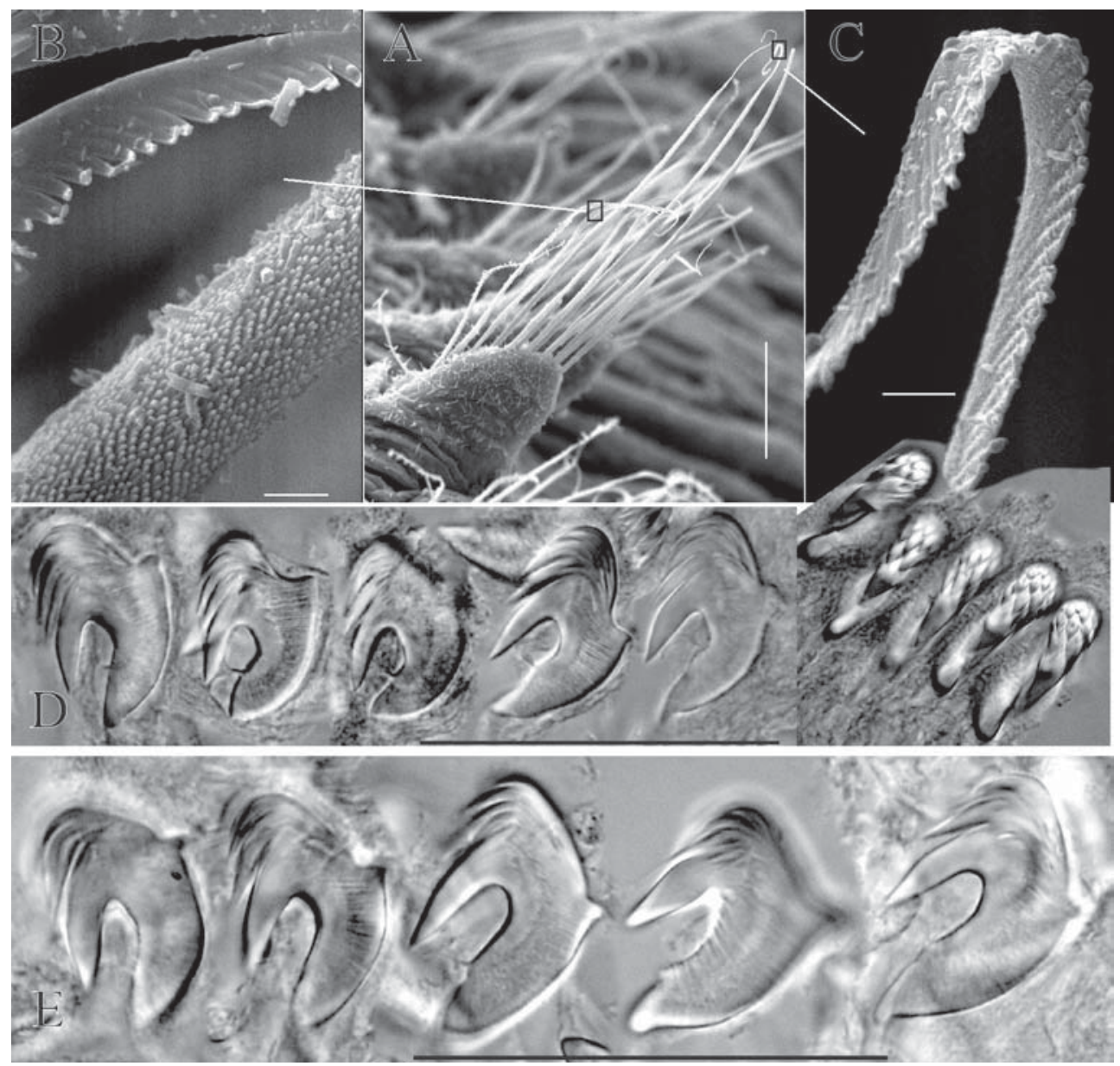

Fig. 17. Amphitrite gracilis (Grube, 1860), chaetae. A-C - notochaetae, Gudauta; B, C - details of A; D, E - uncini, Gudauta: D - TU1; E - AU4. Scale bars: A - $0.1 \mathrm{~mm}, \mathrm{~B}, \mathrm{C}-3 \mu \mathrm{m}, \mathrm{D}, \mathrm{E}-50 \mu \mathrm{m}$.

Рис. 17. Amphitrite gracilis (Grube, 1860), щетинки. А-C - нотохеты, Гудаута; В, С- детали; A; D, E - uncini, Гудаута: D - TU1; E - AU4. Масштаб: A - 0,1 мм, B, C - 3 мкм, D, E - 50 мкм.

than on TU3. Uncinal rows and neuropodia of AU1 two to three times shorter than those of last TC. Uncini avicular. Tube of muddy-detritus, thick walled.

REMARKS. 1. The papillae are clearly visible on S4-S6 but sometimes not visible on other segments, even in comparatively large worms; instead, a porous cushion is present. This difference in the distribution of nephridia seems related to reproduction and other functions of the nephridia.

2. Specimens examined include some collected close to the type locality (Bohuslan, Swe- den) and agree well with Holthe's (1986) description, based on the type.

3. Holthe (1986) reported nephridial papillae on S3-S12 only, but investigated worms show slight variation.

DISTRIBUTION. Boreal Atlantic: European waters from the northern North Sea (type locality Bohuslan, Sweeden) to the south-western Barents Sea, Newfoundland. Below tidal front (lower sublittoral).

Unlikely reports. Reports from the Sea of Japan (Annenkova, 1937, 1938; Uschakov, 1955; Buzhinkaja, 1967) refer to Amphitrite 

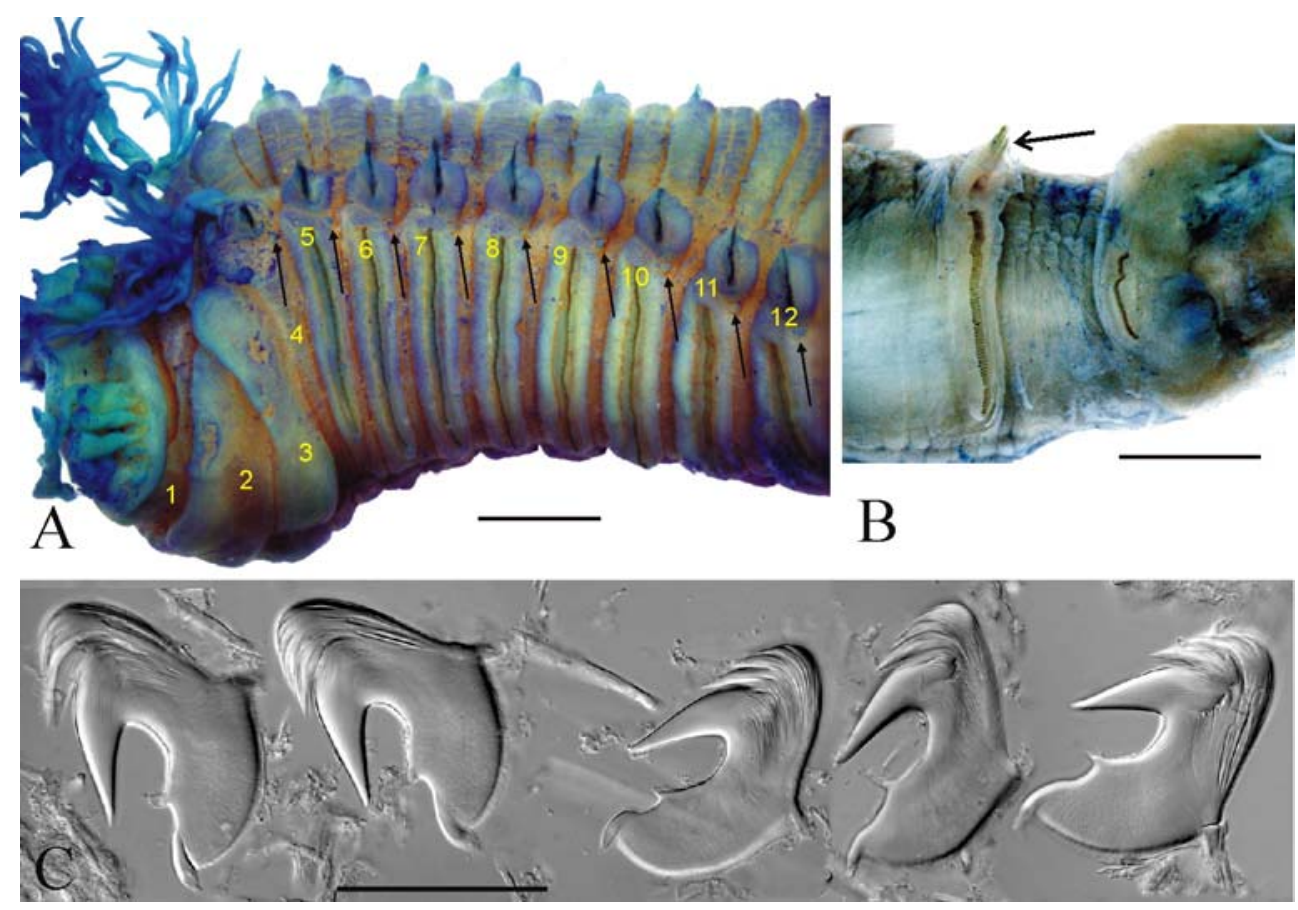

Fig. 18. Amphitrite grayi Malmgren, 1866. A - lateral view, Persey-3 3520; B — thorax-abdomen border, Persey-3 3520; C - uncini TU1, Sevastopol 1354. Scale bars: A, B - $1 \mathrm{~mm}, \mathrm{C}-50 \mu \mathrm{m}$.

Рис. 18. Amphitrite grayi Malmgren, 1866. А - вид сбоку, Персей-3 3520; В - граница торакса и абдомена, Персей-3 3520; C - uncini TU1, Севастополь 1354. Масштаб: А, В - 1 мм, C - 50 мкм.

buzhinskaje (see above). Contrary to Holthe's (1986) statement, totally absent from the Arctic.

\section{Amphitrite groenlandica Malmgren, 1866 Figs 1D, 19.}

Amphitrite groenlandica Malmgren, 1866: 376, fig. 52; Fauvel, 1927: 250-251, fig. 86; Hartmann-Schröder, 1971: 473; Jirkov, 2001: 511-512.

Neoamphitrite groenlandica - Zatsepin, 1948: 157, table XXXVIII, 14; Uschakov, 1955: 392, Fig. 147 G; Pettibone, 1956: 322; Holthe, 1986: 103-104, fig. 44, map 43; Hartmann-Schröder, 1996: 516.

MATERIAL EXAMINED. 27 samples, 43 specimens, from DGEH and ZIN collections (Appendix), 75-388 m.

DESCRIPTION. Up to $190 \mathrm{~mm}$ length. Eyespots absent. Branchiae arborescent with long branches. Lateral lobes of S2-S4: S2 appear as thickenings of anterior margins; small on S3, with upper margin level with middle of TU1 tori, reaching pad ventrally, slightly lower at mid-length; on S4, small to inconspicuous be- low and in front of notopodia. Ventral pads smooth, well separated from neuropodia, completely absent from around TU10. Eleven to thirteen pairs of nephridial papillae: from $\mathrm{S} 3$ to S13-S15; sometimes varying within a single individual: e.g. to $\mathrm{S} 13$ on one side, to $\mathrm{S} 15$ on another. Papillae of S3 lateral to branchiae, lateral to notopodia on S4, others between noto- and neuropodia, posterior to tori; all papillae small.

Notopodia from S4, present on 19 segments. Notochaetae bilimbate, with serrated tips.

Neuropodia from S5, uncini facing forward, TU7-TU18 (last thoracic) uncini in double rows (face-to-face), rows well separated, all neuropodia tori. Thoracic neuropodia large, ventrally almost reaching pads; shorter on TU1 and TU2 than on TU3. Uncinal rows and neuropodia of AU1 about 3/4 to $1 / 2$ length of those of last TC, varying among material from sample sample. Uncini avicular. Tube walls distinctly thick, as wide as inner diameter of tube, muddy. 


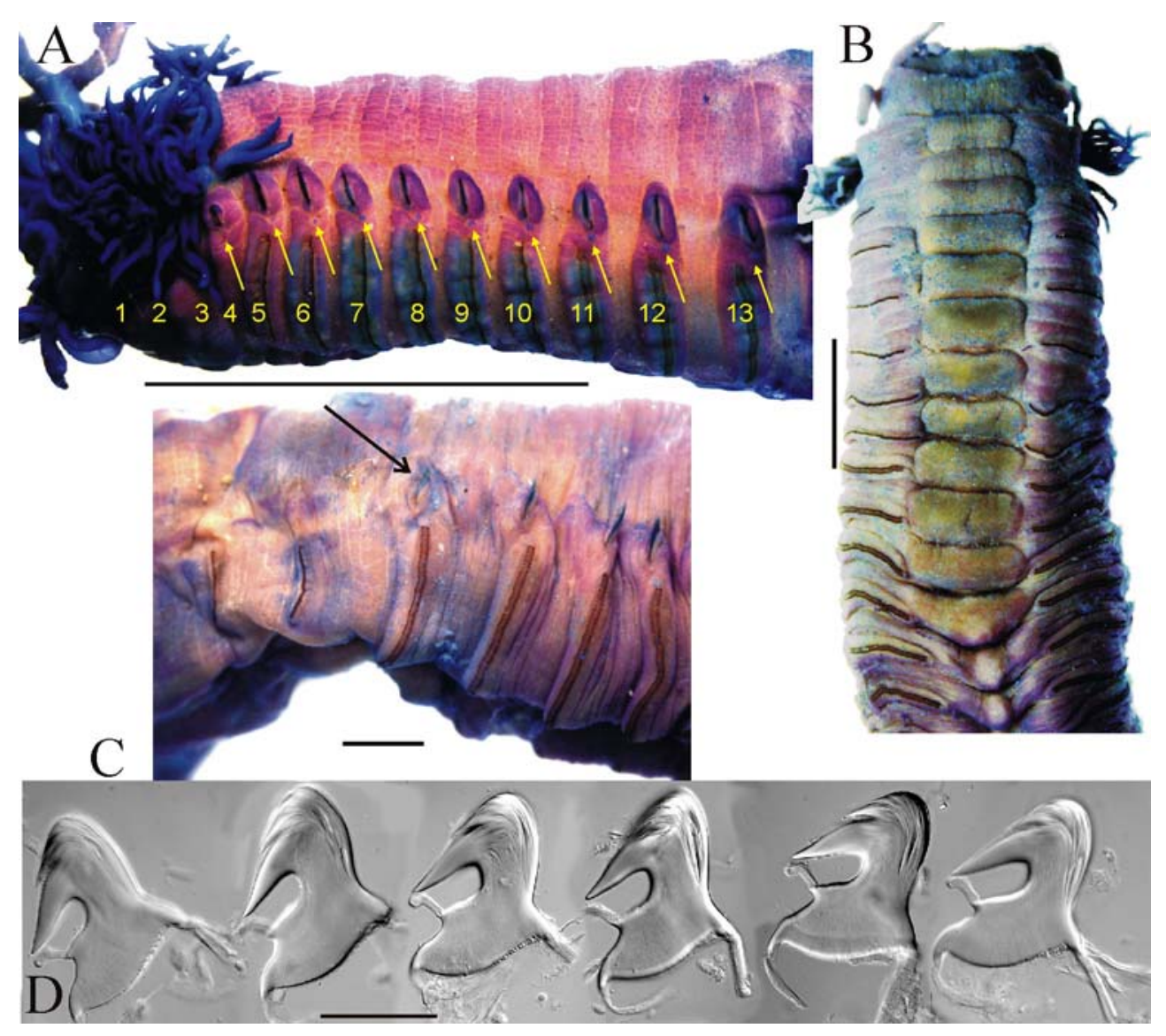

Fig. 19. Amphitrite groenlandica Malmgren, 1866. A - lateral view, Persey 3360; B - ventral view, RT61 26.95; C — thorax-abdomen border, RT-61 26.95; D — uncini TU1, Alaid 7. Scale bars: A - $5 \mathrm{~mm}$, $\mathrm{B}-2 \mathrm{~mm}, \mathrm{C}-1 \mathrm{~mm}, \mathrm{D}-50 \mu \mathrm{m}$.

Рис. 19. Amphitrite groenlandica Malmgren, 1866. А - вид сбоку, Persey 3360; В - вид с брюшной стороны, RT-61 26.95; С - граница торакса и абдомена, РT-61 26.95; D - uncini TU1, Алаид 7. Масштаб: A -5 мм, B -2 мм, $\mathrm{C}-1$ мм, D -50 мкм.

REMARK. Specimens examined agree well with Holthe's (1986) description, based on the type.

Recently published decription of new species A. undevigintipes (Choi, Kim et Yoon, 2020) did not provided with information, allows to differ new species from $A$. groenlandica. Authors wrote: "the new species is clearly differentiated from $N$. groenlandica by two characteristic features. The uncini in the first abdominal chaetiger are arranged in a single row in $N$. undevigintipes sp. nov., but in double rows in $N$. groenlandica, and the new species has 12 ventral shields, but $N$. groenlandica has 14". However both statements are not correct. Probably species differ by the comparative sizes of the last TU and the first AU neuropodia AU1 neuropodia of $A$. groenlandica twice smaller than of last TU while equal in $A$. undevigintipes.

DISTRIBUTION. Type locality Aukpadlartok (West Greenland, $457 \mathrm{~m}$ deep) and Sukkertoppen (Norway, $366 \mathrm{~m}$ deep). High boreal below tidal front (lower sublittoral). Absent in high Arctic. Southermost European reports from middle Norway (Holthe, 1986). Maine. Pettibone (1956) reported depth limits as 15-940 m. 
Unlikely reports. Reports from the North Sea (Hartmann-Schröder, 1996) and western Ireland (Holthe, 1986, unverified records) need in confirmation. Reports from Pacific (Bering Sea to the Sea of Japan and southwestern Alaska) probably belong to $A$. undevigintipes.

\section{Amphitrite rubra (Risso, 1826)}

Fig. 20.

Amphitrite rubra Risso, 1826: 408-409; Fauvel, 1927: 249-250, Fig. 85 h-1 - non Imajima, Hartman, 1964: 337. Terebella multisetosa Grube, 1838: 19-24.

Terebella spiralis Grube, 1860: 97-98.

Terebella compacta Grube, 1863: 55-56, plate V fig. 6.

?Amphitrite incana Claparède, 1870: 129-132, PI. XIII, fig. 6.

MATERIAL EXAMINED. 20 samples (30 specimens) from Mediterranean coasts of Spain (Almería, Málaga, Baleares, Valencia, Chafarinas Is.) and Naples, 3-9 m (MNHN).

ADDITIONAL MATERIAL EXAMINED. A. vigintipes (Grube, 1870) ZIN 1/32269 Nagasaki 26.0.1901.

DESCRIPTION. Fauvel (1927) reported up to $100 \mathrm{~mm}$ length, $8 \mathrm{~mm}$ in diameter and 100 segments. Examined specimens did not exceed $50 \mathrm{~mm}$ in length. Eyespots absent. Branchiae arborescent with thick stem and long branches, first branchiae only slightly larger than third ones. Lateral lobes on S1-S3, poorly developed; lobes of S4 very small. 13-15 pairs of nephridial papillae: first three on S3-S5, long, cylindrical, at least twice size of others; others small, wart-like, between noto- and neuropodia; number of papillae may vary within same worm, from one side of body to another. Ventral pads to ca. TU11.

Notopodia from S4, present on 22-24 segments. Notochaetae of two types, longer and shorter, both narrow, bilimbate, with serrated tips.

Neuropodia from S5, uncini facing forwards, in double rows (face-to-face) from TU7, almost to end of body, rows well separated; all neu- ropodia tori, gradually reducing in size towards pygidium; no abrupt change in size of neuropodia, either from thorax to abdomen or at transition between neuropodia with double rows of uncini to those with single-rows. Length of anterior neuropodial tori at least as long as width of widest ventral pad. Uncini avicular with short tendon. Preserved specimens colourless. Fauvel (1927) reported body of variable colour: pinkish white to wine-coloured and reddish; gills red, tentacles white.

REMARKS. 1. Hutchings \& Glasby (1988: 4) wrote: "A type of $A$. rubra has been examined (MNHN UB 392) and the specimen does not belong in the genus Amphitrite". The short redescription of the paratype (MNHN UB 392) was published later (Hutchings, Glasby, 1995), with the conclusion that the species probably belonged to Longicarpus Hutchings, Murray, 1984, as the paratype had "anterior uncini longhandled" (p. 152). However, close examination of their drawing (Fig. 2b, reproduced Fig. 19F) shows that the appendage they call long-handled is actually short and the figured uncini, as well as the uncini of the examined worm, do not much differ from TU1 uncini of other Amphitrite, especially from those of $A$. vigintipes (Fig. $19 \mathrm{G})$. Also, they mentioned "Nephridial papillae on segments 3-5 and possibly 6", which corresponds with my observation: papillae on S3-S5 much more visible than on subsequent segments, which may not be visible at all, being replaced by pads in mature females, as in $A$. fauveli (Jirkov et al., 2018). The only difference is the number of notopodia: "19 pairs on segments 5 to 23; posterior segments with few or no notosetae" (Hutchings, Glasby, 1995). The difference may be either individual variation or (more probably) notochaetae lost during preservation. In either case, I do not consider the difference significant enough even to change the species diagnosis. Unfortunately, I cannot investigate Hutchings \& Glasby's (1988)

Pис. 20. Amphitrite rubra (Risso, 1826) and A. vigintipes (Grube, 1870). А — вид сбоку, MNCN 478; В вид с брюшной стороны, MNCN 478; C - граница торакса и абдомена, MNCN 478; D - нотохеты TC22, MNCN 1756; E — uncini TU1, MNCN 1756; F — MNHN UB 392 перерисовано из Hutchings and Glasby (1995); G - A. vigintipes (Grube, 1870) ZIN 1/32269, uncini TU 1. Масштаб: A — 5 мм, B - 2 мм, $\mathrm{C}-1$ мм, $\mathrm{D}-0,2$ мм, $\mathrm{E}-\mathrm{G}-50$ мкм. 


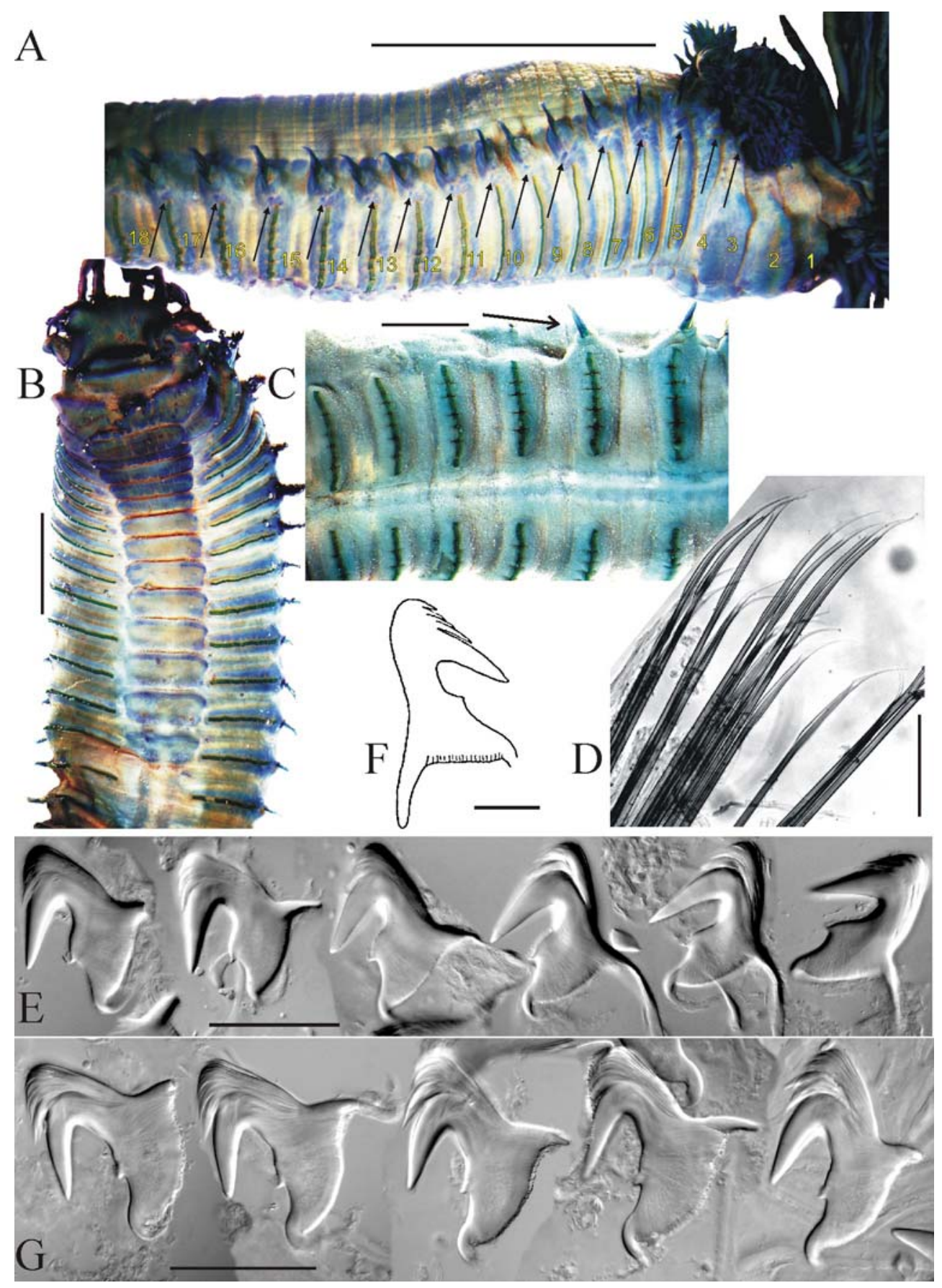

Fig. 20. Amphitrite rubra (Risso, 1826) and A. vigintipes (Grube, 1870). A — lateral view, MNCN 478; B ventral view, MNCN 478; C - thorax-abdomen border, MNCN 478; D — notochaetae TC22, MNCN 1756; E - uncini TU1, MNCN 1756; F — MNHN UB 392 redrawn from Hutchings and Glasby (1995); G - A. vigintipes (Grube, 1870) ZIN 1/32269 uncini TU 1. Scale bars: A $-5 \mathrm{~mm}, \mathrm{~B}-2 \mathrm{~mm}, \mathrm{C}-1 \mathrm{~mm}, \mathrm{D}-$ $0.2 \mathrm{~mm}, \mathrm{E}-\mathrm{G}-50 \mu \mathrm{m}$. 
paratype as "there is no trace of this species in the database" (e-mail from Prof. Meziane, curator of the MNHN collection of Polychaeta 21/ $01 / 2017)$. In this paper, A. rubra is accepted in the sense of Fauvel (1927) as studied specimens agree well with the generic diagnosis above and Fauvel's (1927) species description.

2. Terebella multisetosa Grube, 1838 (type locality Italy), according to the original description, has three pairs of branchiae and $22 \mathrm{TC}$. The only species which matches these characters in the investigated area is $A$. rubra, so I agree with Fauvel (1927) that these species are synonyms.

3. Terebella spiralis Grube, 1860 (type locality Cherso, Greece), according to the original description, has 22-25 TC and nephridial papillae up to (and including) S17. The only species which matches these characters in the investigated area is A. rubra. I do not consider small differences in number of TC and nephridial papillae to be important enough to separate species, so I agree with Fauvel (1927) that these species as synonyms.

4. Terebella compacta Grube, 1863 (type locality Croatia), according to the original description, has three pairs of branchiae, 22-23 $\mathrm{TC}$, and ventral pads occupying a small part of the ventral surface. The only species which matches these characters in the investigated area is Amphitrite rubra, so I agree with Fauvel (1927) that these species as synonyms.

5. Amphitrite incana Claparède, 1870 (type locality Gulf of Naples), according to the original description, has three pairs of branchiae and $23 \mathrm{TC}$, as do members of A. rubra. However, as the figured notochaetae seem geniculated the species may belong to Terebella.

DISTRIBUTION. Type locality Nice, Southern France. Probably Mediterranean endemic, above the tidal front (upper sublittoral).

Unlikely reports. Widely reported; however, close examination shows that at least some records are based on misidentifications. For example, Australian waters are inhabited by $A$. pachyderma (Hutchings, Glasby, 1988), instead of A. rubra. Imajima \& Hartman (1964) reported only $20 \mathrm{TC}$ (distinctly less than for European specimens) for specimens from Japan (Imajima,
Hartman, 1964: 337): "uncini... in double rows from the seventh (TU? - IJ) to the first abdominal parapodia. Nephridial papillae occur on segments 3 to 15 ". Obviously, this is a quite different species, as Mediterranean specimens have uncini in double rows almost to the end. I also investigated a specimen of $A$. vigintipes with $22 \mathrm{TC}$ and uncini in double rows almost to the pygidium (ZIN 1/32269); it has only six pairs of nephridia (S3-S8), as previously mentioned by Marenzeller (1884); it is obviously a quite different species, although Imajima \& Hartman (1964) regarded it as a junior synonym of $A$. rubra. So, considering the existence of two species that may be confused with A. rubra, the presence of this species in Japanese waters requires verification.

\section{Amphitrite rzhavskyi Jirkov, sp.n.} Figs 1F-H, 21, 22.

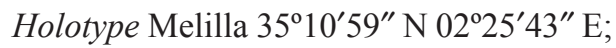
missing posterior end, but otherwise well-preserved (MNCN 16.01/17775).

Paratypes: Mediterranean, Melilla: MNCN 16.01/5479 (1 specimen), UK: APEM 487849, Loch Spelve KGB MGU-Pol-37 (2 sp.); APEM 41398 Loch Sunart KGB MGU-Pol-38 (1 specimen); APEM518609 Summer Isles KGB MGUPol-39 (2 specimens); APEM489074 Sound of Mull KGB MGU-Pol-40 (1 specimen).

ETYMOLOGY. Species is named after my late friend Dr. Alexandr Rzhavsky (Fig. 23).

ADDITIONAL MATERIAL EXAMINED. A. oculata Hessle, 1917: 3 samples (5 specimens) from Japan ZIN 1/31909 Misaki, Okayama 10-15 m 23.07.1917 (1 spec.); ZIN 2/31910 Tsuruga, Fukui 15-20 m 1917 (2 specimens); ZIN 3/31911 3.3.1911 Misaki, Okayama (2 specimens). A. kerguelensis McIntosh, 1876: MNCN $355862^{\circ} 38^{\prime} \mathrm{S} 60^{\circ} 40^{\prime} \mathrm{W} 21.01 .1995$ (1

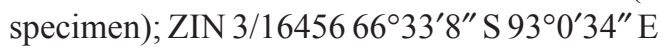

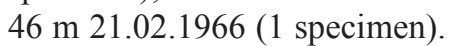

DESCRIPTION (based on holotype and paratypes). Up to $100 \mathrm{~mm}$ in length, $6 \mathrm{~mm}$ width; paratypes with $17 \mathrm{TC}$ and about $50 \mathrm{AU}$. Long buccal tentacles, about as long as body length or longer. Eyespots absent. Branchiae as 


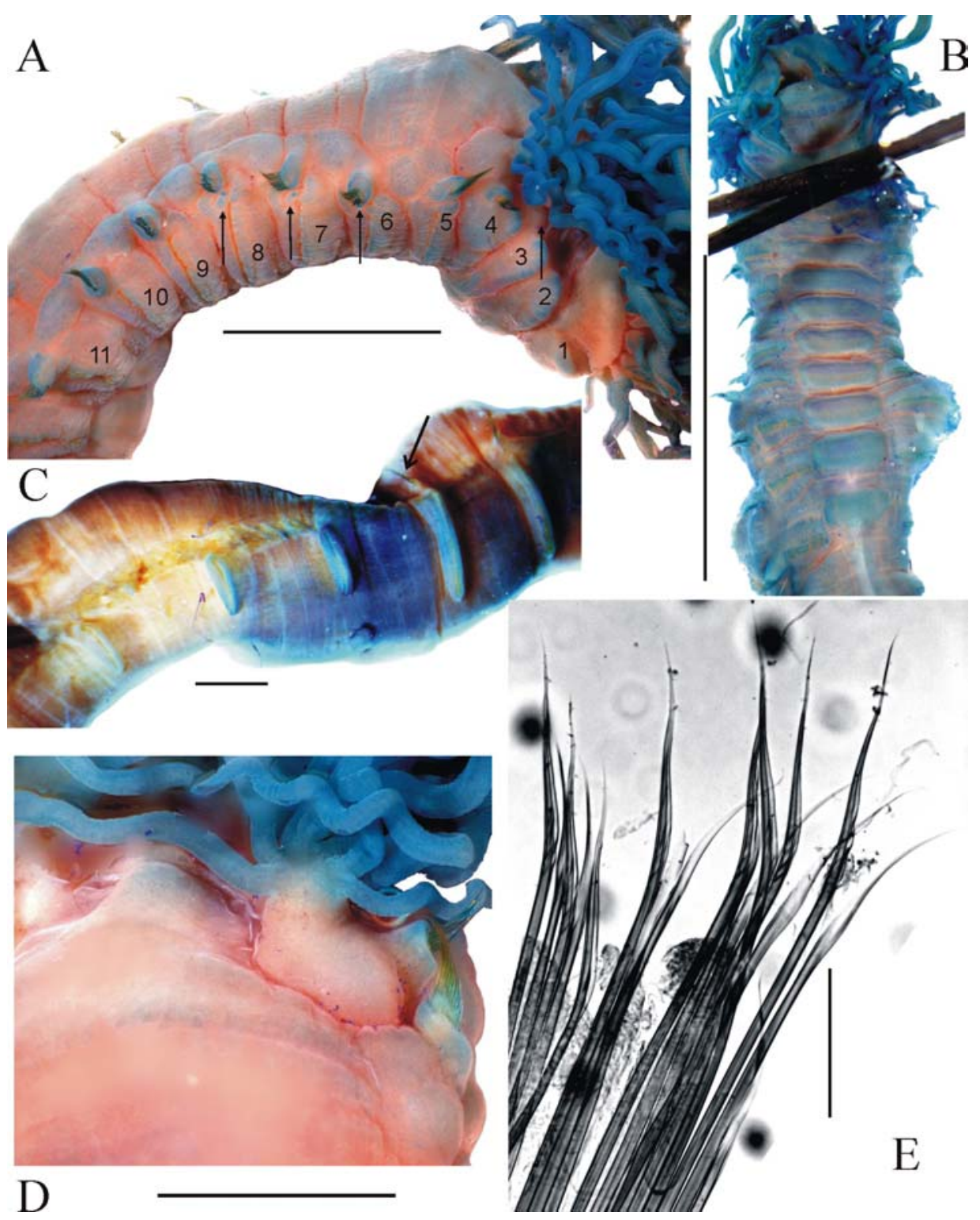

Fig. 21. Amphitrite rzhavskyi Jirkov, sp.n., external morphology. A - lateral view, holotype; B — ventral view, holotype; C - thorax-abdomen border, holotype; D - branchia, holotype; E - notochaetae TC14, MNCN 5479. Scale bars: A $-2 \mathrm{~mm}, \mathrm{~B}-5 \mathrm{~mm}, \mathrm{C}, \mathrm{D}-1 \mathrm{~mm}, \mathrm{E}-0.2 \mathrm{~mm}$.

Рис. 21. Amphitrite rzhavskyi Jirkov, sp.n., внешняя морфология. А - вид сбоку, голотип; В - вид с брюшной стороны, голотип; C - граница торакса и абдомена, голотип; D - жабра, голотип; Е нотохеты TC14, MNCN 5479. Масштаб: A - 2 мм, B - 5 мм, C, D - 1 мм, E - 0,2 мм.

numerous simple filaments, arising from tip of stem. Stem with broad base, upper half abruptly narrowing on outer side, while inner side remains as basally. S1 forms ventral collar. Lobes of S2-S4 small gradually reduced backwards. Ventral pads up to TU9, smooth. Four pairs of nephridial papillae: one pair laterally from second par of branchiae (S3), very large almost half 

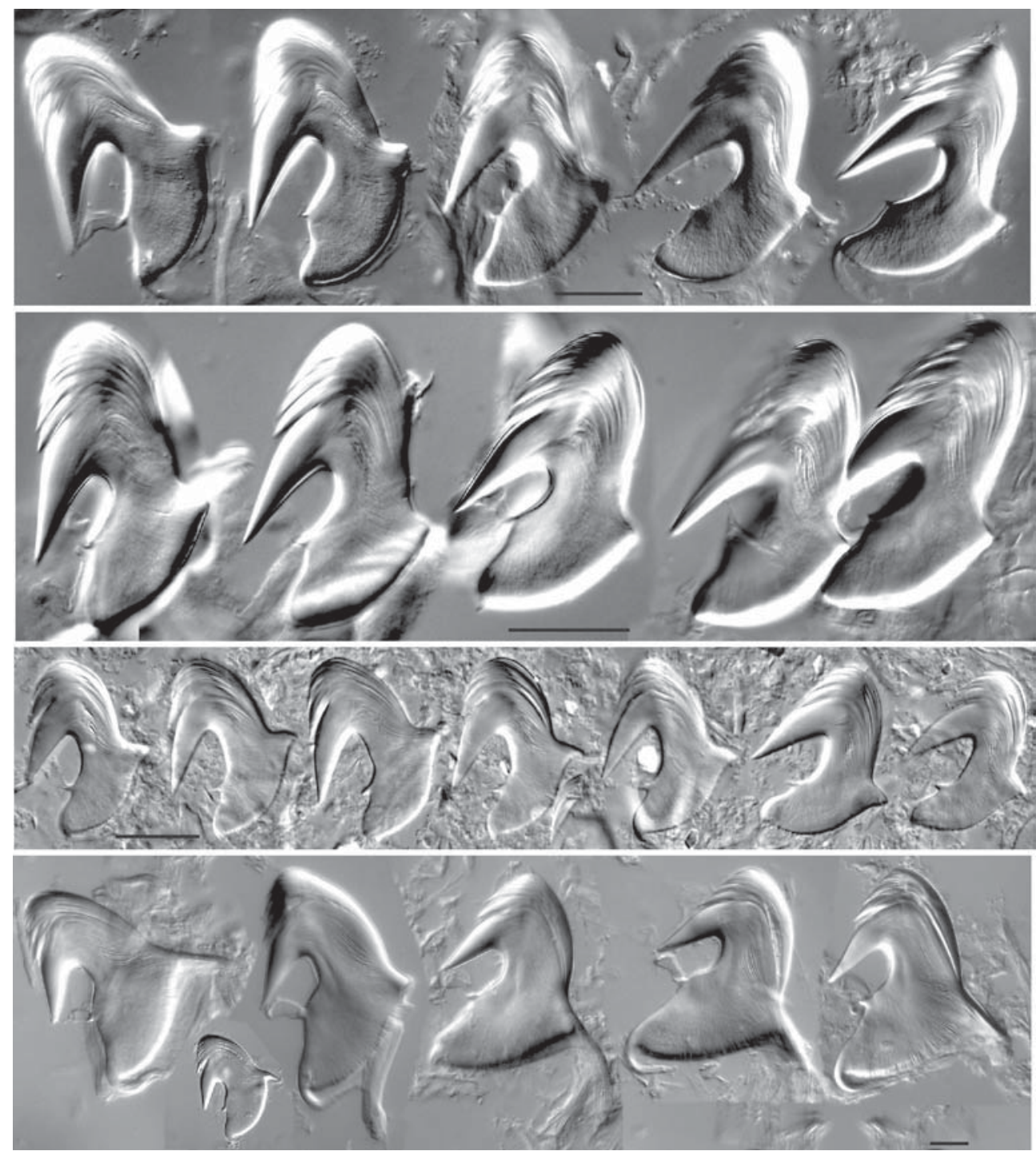

Fig. 22. Amphitrite rzhavskyi Jirkov, sp.n., chaetae. A — uncini TU1, MNCN 5479; B - uncini A26, MNCN 5479; C - A. oculata Hessle, 1917, ZIN 3; D - A. kerguelensis McIntosh, 1876, MNCN 3558. Scale bars: $20 \mu \mathrm{m}$.

Рис. 22. Amphitrite rzhavskyi Jirkov, sp.n., щетинки. A - uncini TU1, MNCN 5479; B - uncini A26, MNCN 5479; C - A. oculata Hessle, 1917, ZIN 3; D - A. kerguelensis McIntosh, 1876, MNCN 3558. Масштаб: 20 мкм.

size of first notopodia; three much smaller pairs between noto- and neuropodia of S6-S8; S4 and S5 without papillae.

Notopodia from S4, present on 17 segments. Notochaetae assymetrically bilimbate, with serated tips.
Neuropodia (uncini facing forward) from C2. Uncini in double rows (uncini face-to-face) on TU7-TU16 (end of thorax), all abdominal neuropodia with uncini in single rows (uncini facing forwards). All neuropodia large, first nine pairs reaching ventral pads. Tori of anterior 


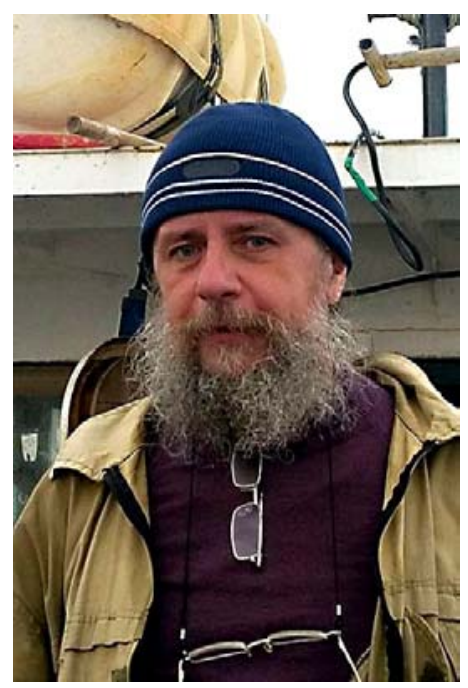

Fig. 23. Dr. Alexandr Vladimirovich Rzhavsky (25.08.1959-30.07.2018). Photo: T.A. Britaev.

Рис. 23. Александр Владимирович Ржавский (25.08.1959-30.07.2018). Фото Т.А. Бритаева.

neuropodia at least as long as width of widest ventral pad. Tori of AU1 less than half length of tori of last TU. Uncini avicular, thoracic and abdominal uncini all similar. Pygidium crenulate, without papillae. Tube unknown.

REMARKS. The new species differs from other Amphitrite species with cirriform branchiae in the shape of its branchiae. Branchial filaments of $A$. rzhavskyi sp.n. arise from assymetrical stem, while $A$. cirrata (Fig. 9D), A. oculata and $A$. fauveli (Fig. 24A, also see Jirkov et al., 2018, Fig. 2A-C) have branchial filaments arising from a very short, wartlike stem or directly from the body wall; A. kerguelensis has the filaments of third branchiae arising from the inner side of a large stout stem (Fig. 24B). The new species is similar to $A$. fauveli and $A$. oculata, in having 4 pairs of nephridial papillae, which differs them from $A$. kerguelensis having 7 pairs of papillae (Fig. 3B) and A. cirrata (Fig. 3A) having 8 pairs of papillae. A. rzhavskyi sp.n. similar to other Amphitrite with cirriform branchiae, but A. kerguelensis, by the absence of nephridial papillae on S4 and S5, and absence of a high dorsal collar. A. kerguelensis has this papillae (Fig. 24D), and branchiae on S4 attach to a high dorsal collar (Fig. 24B). The TU1 uncini of the new species differ from other Amphitrite with cirriform branchiae (Figs 10D, E, 22C, D, also see Jirkov et al., 2018, Fig.) in their distinctly narrower necks; they are most similar to those of A. oculata (Fig. 22C), but differ from the last by more numerous teeth in a crest and more rounded base margin between prow and heel.

I also consider the species' distinct range as evidence of its validity. All species with cirriform branciae have different ranges. A. rzhavskyi sp.n. is found in the upper sublittoral Mediterranean and western European waters, north to the north-western UK. A. cirrata inhabits shelf waters of Arctic and boreal regions of the northern Atlanic and northern Pacific. A. fauveli inhabits slope waters of the north-eastern Atlantic. A. oculata is reported from Japan (Hessle, 1917; Imajima, Hartman, 1964, our data), Australia (Hutchings, Glasby 1988) and Italy (Castelli et al., 2008). However, considering the similarity between individuals of $A$. rzhavskyi sp.n. and $A$. oculata, it is highly likely that the report from Italy actually belongs to $A$. rzhavskyi sp.n. The range of $A$. kerguelensis is limited to the Southern Ocean.

DISTRIBUTION. Currently known from the upper sublittoral from northern Scotland to the Mediterranean; judging by Pista unibranchia Day, 1963, which in the Mediterranean is limited to upper sublittoral depths, it is expected above the tidal front (upper sublittoral) further south, at least probably to the Gulf of Guinea and even as far as the Indian Ocean.

\section{Amphitrite variabilis (Risso, 1826) sensu Fauvel, 1927}

Fig. 25.

Terebella variabilis Risso, 1826: 408-409. $\mathrm{f}, \mathrm{g}$.

Amphitrite variabilis Fauvel, 1927: 247-248, Fig. 85

MATERIAL EXAMINED. 21 samples (26 specimens) from Mediterranean coasts of Spain (Valencia), North Africa (Melilla), and Naples (MNHN and ZIN: 1/3267, 2/32268).

DESCRIPTION. Fauvel (1927) reported up to $150 \mathrm{~mm}$ length. Examined specimens seen not to exceed $55 \mathrm{~mm}$ in length. Eyespots absent. Branchiae arborescent. Lobes poorly developed on S3 \& S4, better developed on S2 but still 


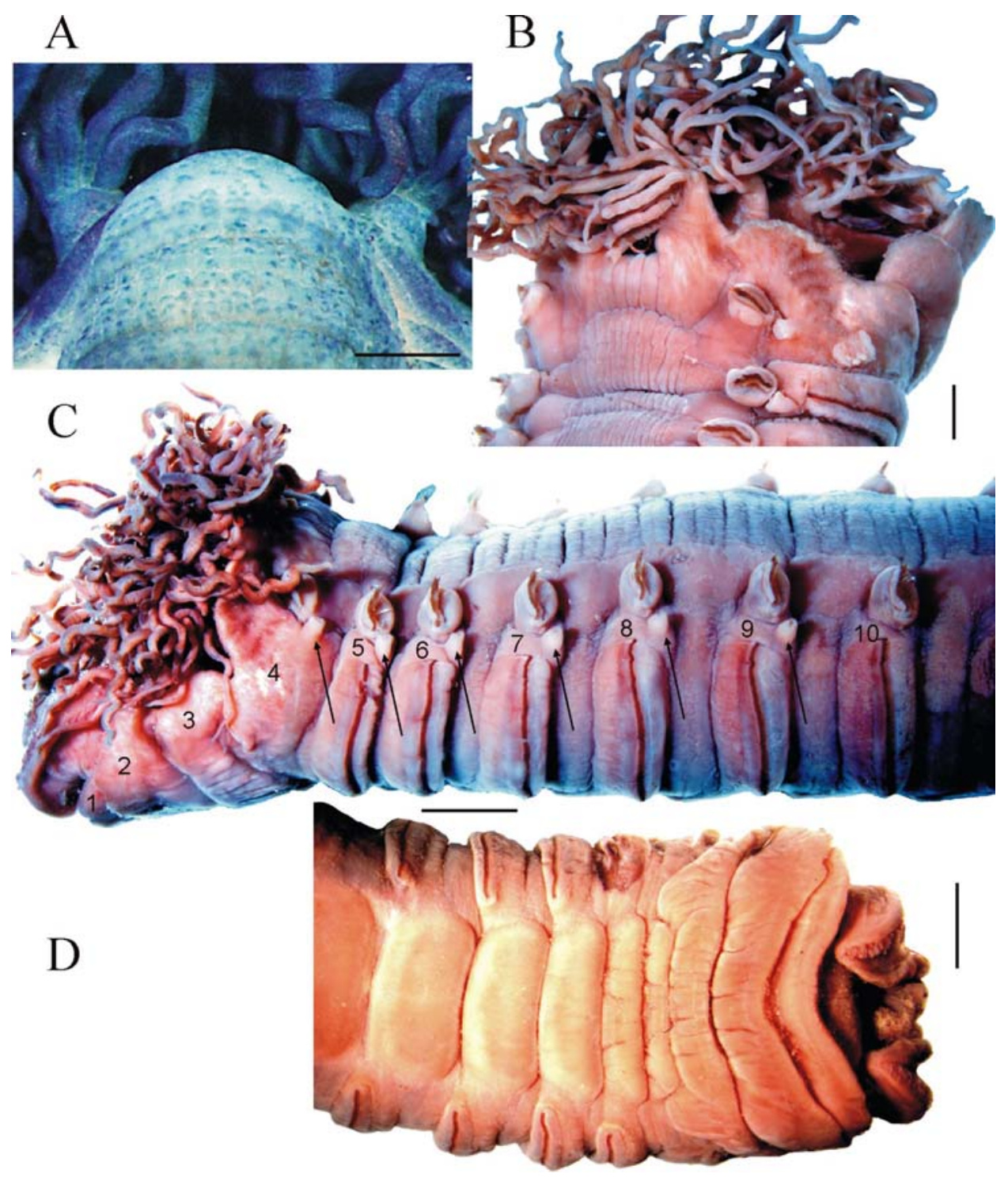

Fig. 24. Amphitrite fauveli Jirkov, Ravara et Cunha, 2018 and A. kerguelensis McIntosh, 1876. A branchia A. fauveli (after Jirkov et al., 2018); B-D - A. kerguelensis, MNCN 3558: B - branchia, C lateral view, D - ventral view. Scale bars: A, B - $1 \mathrm{~mm}, \mathrm{C}, \mathrm{D}-2 \mathrm{~mm}$.

Рис. 24. Amphitrite fauveli Jirkov, Ravara et Cunha, 2018 и A. kerguelensis McIntosh, 1876. А - жабра A. fauveli (after Jirkov et al., 2018); B-D - A. kerguelensis, MNCN 3558: B — жабра, C - вид сбоку, $\mathrm{D}$ - вид с брюшной стороны. Масштаб: А, В - 1 мм, С, D - 2 мм.

small. Ventral pads smooth, well separated from neuropodia; last pad on ca. TU10. Six pairs of almost equal-sized nephridial papillae on S3S8: lateral to branchiae on S3; lateral and slightly posterior to notopodia on S4; between notoand neuropodia on S5-S8, on posterior margin of neuropodia. First three pairs cylindrical, others as small warts between noto- and neuropodia, slightly posterior to row of uncini.

Notopodia from S4, present on 17 segments. Notochaetae of two types, long and shorter, both bilimbate, with serrated tips. 


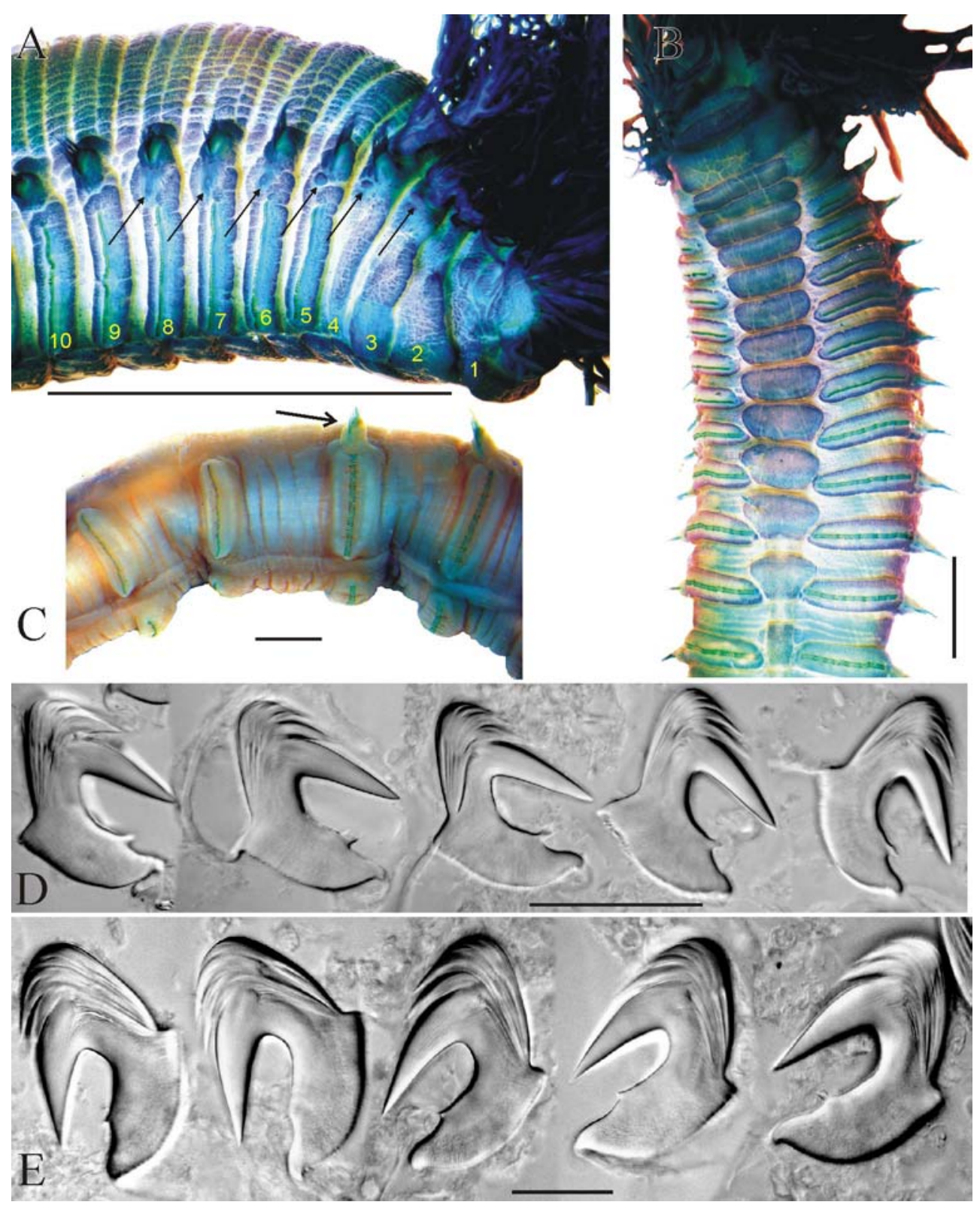

Fig. 25. Amphitrite variabilis (Risso, 1826) sensu Fauvel, 1927. A — lateral view, MNCN 653; B — ventral view, MNCN 653; C - thorax-abdomen border, MNCN 653; D - uncini TU1, MNCN 1773; E - uncini AU35, MNCN 1773. Scale bars: A $-5 \mathrm{~mm}, \mathrm{~B}-2 \mathrm{~mm}, \mathrm{C}-1 \mathrm{~mm}, \mathrm{D}-50 \mu \mathrm{m}, \mathrm{E}-20 \mu \mathrm{m}$.

Рис. 25. Amphitrite variabilis (Risso, 1826) sensu Fauvel, 1927. А - вид сбоку, MNCN 653; В - вид с брюшной стороны, MNCN 653; C - граница торакса и абдомена, MNCN 653; D - uncini TU1, MNCN 1773; E - uncini AU35, MNCN 1773. Масштаб: A - 5 мм, B - 2 мм, C - 1 мм, D - 50 мкм, E 20 мкм. 
Neuropodia (uncini facing forward); from S5: uncini in double rows (face-to-face) on TU7-TU16, rows well separated, thoracic and abdominal neuropodia tori, thoracic neuropodia reaching ventral pads. Uncinal rows of anterior neuropodia at least 1.5 times as long as width of widest ventral pad. All neuropodia tori; no abrupt change in size or shape of neuropodia between thorax and abdomen. Uncini avicular; thoracic and abdominal uncini all similar.

REMARKS. Amphitrite variabilis is similar to $A$. affinis in terms of the number of TC, nephridia, and branchiae. Probably for this reason, $A$. affinis has been recorded from as far from its true range as Iberian waters. These two species differ in the shape of their uncini: narrower and with longer necks in $A$. variabilis than in members of $A$. affinis.

The original description is not satisfactory and I am not sure that Risso (1826) had this species at hand. In this paper, the species is accepted in the sense of Fauvel (1927).

DISTRIBUTION. Type locality Nice, Southern France. The species seems to be endemic to the Mediterranean (upper sublittoral).

\section{Discussion of generic synonymy}

Status of Neoamphitrite Hessle, 1917

One of the reasons for establishing Neoamphitrite was the shape of the branchiae, which differs from Amphitrite. Those of Amphitrite s.str. are described as "short filaments" (Uschakov, 1955: 392), "sessile filaments" (Fauchald, 1977: 129) or "simple filaments" (Holthe, 1986: 93). The type species of Amphitrite, A. cirrata, has filaments attached to a reduced stem; the filaments are usually unbranched: among examined specimens of $A$. cirrata, 12 have unbranched filaments arising directly from one point on the body wall, 88 have unbranched filaments arising from a reduced stem and 7 have branchiae with at least some branched filaments. Hutchings \& Glasby (1988) also mentioned that "some species such as Amphitrite robusta Johnson, 1901 have branchiae which are intermediate between those of Amphitrite sensu stricto and those of Neoamphitrite" (p. 3). Some other

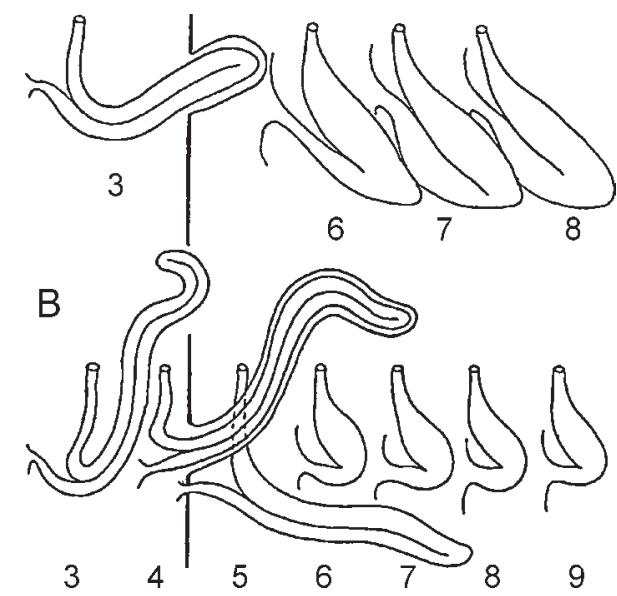

Fig. 26. Nephridial system of Amphitrite and Neoamphitrite. A - Amphitrite (species figured by Hessle is probably A. oculata Hessle, 1917 as this was the only species with four pairs of nephridia known at that time); B - Neoamphitrite. Modified from Hessle (1917). Numbers refer to segment number.

Рис. 26. Нефридиальная система Amphitrite и Neoamphitrite. A - Amphitrite (изображена вероятно A. oculata Hessle, 1917, поскольку в то время это был едиственный известный вид с четыремя парами нефридиев); В - Neoamphitrite. По Hessle (1917). Цифры — номера сегментов.

species of Amphitrite s.str. (A. kerguelensis and A. rzhavskyi sp.n.) have branchiae with a distinct stem.

Hessle (1917) also used the structure of the nephridial system for distinguishing Neoamphitrite from Amphitrite (Fig. 26). However, for most species this information is absent and so cannot be used at the present stage of our knowledge. It also requires dissection and cannot be applied to rare species or type material. Hessle (1917) did not use type species of Amphitrite and Neoamphitrite as examples of the nephridial system. He pictured Amphitrite with four pairs of nephridia (the only Amphitrite known at that time with this number was $A$. oculata) and Neoamphitrite with seven pairs of nephridia; the only Amphitrite known at that time with this number was $A$. kerguelensis (see above) and it does not belong to Neoamphitrite sensu Hessle, 1917. Also, according to Hessle (1917), Amphitrite differs from Neoamphitrite in the absence 
of nephridia on segments S4 and S5. This is true for all species with cirriform branchiae from the Northern Hemisphere, but not for A. kerguelensis, so the absence of nephidial papillae on S4 and S5 and the structure of branchiae are independent characters that may combine in different ways.

Fauchald (1977) also distinguished Amphitrite from Neoamphitrite by their lateral lobes: absent in Amphitrite, present in Neoamphitrite. However, Hessle (1917) reported both genera as having lateral lobes. According to my data, there is no difference between European species (including types of both genera) in the development of lateral lobes; usually, the lobes are small, but $A$. kerguelensis has large lateral lobes on S4 (Fig. 24C) and small on S1-S3.

In conclusion, there is no valid reason to accept Neoamphitrite as a distinct genus. This is even reflected in WoRMS: Amphitrite grayi Malmgren, 1866 is listed in WoRMS as Amphitrite grayi (Read, Fauchald, 2020c) and also as Neoamphitrite grayi (Read, Fauchald, 2020d). The same is true for Amphitrite edwardsii, which is listed in WoRMS as Amphitrite edwardsii (Read, Fauchald, 2020e) and also as Neoamphitrite edwardsi (sic!) (Read, Fauchald, 2020f). So I agree with many authors (Fauvel, 1927; Pettibone, 1954; Imajima, Hartman, 1964; Day, 1967; Hutchings, Glasby, 1988; Hutchings et al., 2017) that Neoamphitrite should be accepted as a junior synonym of Amphitrite.

\section{Status of Amphitritides Augener, 1922}

Amphitritides differs from Amphitrite by:

- Two pairs of branchiae and neuropodia with double rows of uncini through most of the abdomen (Augener's original diagnosis). However, some species currently assigned to Amphitrite have two pairs of branchiae and at least $A$. rubra and $A$. vigintipes have neuropodia with double rows of uncini throughout most of the abdomen; nevertheless, both are so similar to other species of Amphitrite that I have no doubt of their generic affiliation.
- The number of TC: 16-17 in Amphitrite; 18 or more in Amphitritides (Fauchald, 1977). This is obviously not correct, as no presently known species of Amphitrite has 16 TC, while Amphitrite glasbyi Londoño-Mesa, CarreraParra, 2005 has 39 TC.

- Absence of lateral lobes (Holthe, 1986; Hartmann-Schröder, 1996; Londoño-Mesa, 2009). The development of lateral lobes in Amphitrite varies to a great extent, from poorly developed or absent (A. groenlandica) to welldeveloped (A. kerguelensis); these lobes are less well-developed than in Axionice or Scionella (Jirkov, Leontovich, 2017). Small worms of all investigated species have lobes that are poorly-developed or absent. The situation is quite different from Axionice and Pista, in which small specimens have well-developed lateral lobes (see Jirkov, Leontovich, 2017). So, this character does not seem good enough to be used at the generic level in the Amphitrite-Amphitritides case.

In summary, I see no characters that allow differentiation between Amphitritides and Amphitrite. This is even reflected in the generic affinities of species. For example, Amphitritides pectinobranchiata Hartmann-Schröder, 1965 is obviously closer to species assigned to Amphitrite (A. birulai and A. pauciseta) at the time of its description than to Amphitritides, as Arvanitidis \& Koukouras (1995) correctly stated. Parapar et al. (1991) also mentioned the similarity between Amphitritides and Paramphitrite. The notochaetae and uncini, development of nephridial papillae (absence on $\mathrm{S} 4$ and $\mathrm{S} 5$, as in many species of Amphitrite) and development of ventral pads (limited to ventral surface) are exactly the same in Amphitritides gracilis as in Amphitrite. So, to my mind, Amphitritides should be accepted as another junior synonym of Amphitrite.

Status of Paramphitrite Holthe, 1976

Both genera may have two pairs of branchiae: all species of Paramphitrite, and some of Amphitrite. Paramphitrite has fewer TC, only 13-14 but, taking into account that different 
species of Amphitrite have 15-45 TC, this difference does not seem reasonable to separate genera. Nephridial papillae in Paramphitrite are present on S3, and S5-S8 or S6-S8, between parapodial lobes, exactly as in some species of Amphitrite. Uncini are in double rows on S11S20, as with over half the species of Amphitrite. Both genera have more or less developed lateral lobes at S2-S4. According to Holthe (1976), Paramphitrite differs from Amphitrite in the presence of arborescent branchiae (first pair) and from Neomphitrite in the presence of almost cirriform branchiae (second pair); as I consider Neomphitrite to be a junior synonym of Amphitrite, this does not matter. According to Holthe (1976), Amphitritides differs from Paramphitrite in having branchiae with distinct stems and the absence of lateral lobes. However, Amphitrite birulai, a species previously included in Paramphitrite and, as shown below, the senior synonym of the type species of Paramphitrite, has both pairs of branchiae with distinct stems, if the worm and, accordingly, branchiae are large enough. In summary, I see no character that allows differentiation between Paramphitrite and Amphitrite. So, I consider Paramphitrite should be accepted as a junior synonym of Amphitrite.

\section{Species included in Amphitrite}

Amphitrite, in the sense accepted here (including Amphitritides, Neoamphitrite and Paramphitrite as junior synonyms), includes (Table 1) 42 distinct species: 39 described and valid and two described herein (plus $A$. sp. A sensu Kritzler, 1984). Many of the nominal species were poorly described and re-investigation of type material (which does not always exist) or topotypes is necessary.

\section{Taxonomic position of species ex- cluded from the genus Amphitrite}

Amphitrite harpa Hutchings et Glasby, 1988 has different types of notochaetae, straight on anterior notopodia and geniculated on posterior ones, like many Terebella. So, Arvanitidis \&
Koukouras (1995) supposed that this species should be transferred to Terebella. I agree with them.

Amphitrite lobocephala Hsieh, 1994. According to characters mentioned in the original description (shape of branchiae, arrangement of lateral lobes, uncini arranged back-to-back and others), this species agrees well with species formerly belonging to Lanice. Nogueira et al. (2013) came to the same conclusion, but did not make the necessary taxonomic amendments. I do not understand why it was described under Amphitrite. Our phylogenetic analysis (Jirkov, Leontovich, 2017) shows that it should be transferred to Axionice, as we consider that Lanice should be accepted as its junior synonym.

Amphitrite luna Dalyell, 1853 (type locality Scotland) and A. ramosa Risso, 1826 (type locality Mediterranean France) are indeterminable because their original descriptions did not provide sufficient details, so I consider it better to accept them as nomina dubia (glossary of ICZN: "a name of unknown or doubtful application") and to disregard them.

Amphitrite meckelii Delle Chiaje, 1828 (as Anphitrite di Meckel, type locality Gulf of Naples) was synonymised by Fauvel (1909) with Eupolymnia nebulosa (Montagu, 1819), without any argumentation. The original description does not provide enough information even to be sure about generic affiliation.

Amphitrite olfersii Delle Chiaje, 1828 (as Anphitrite dì Olfers, type locality Gulf of Naples) was synonymised by Fauvel (1909) with Amphitrite rubra without any argumentation. The original description does not provide enough information even to be sure in generic affiliation.

The notochaetae pictured in the original description of Amphitritides kuehlmanni Arvanitidis et Koukouras, 1995 are geniculated and the species probably belongs to Terebella; however until a re-examination of the types is performed, it is better to keep this species inside Amphitrite.

Terebella laevirostris Claparède, 1869 (type locality Gulf of Naples) was synonymised, with doubt, by Fauvel (1927) with Amphitrite graci- 

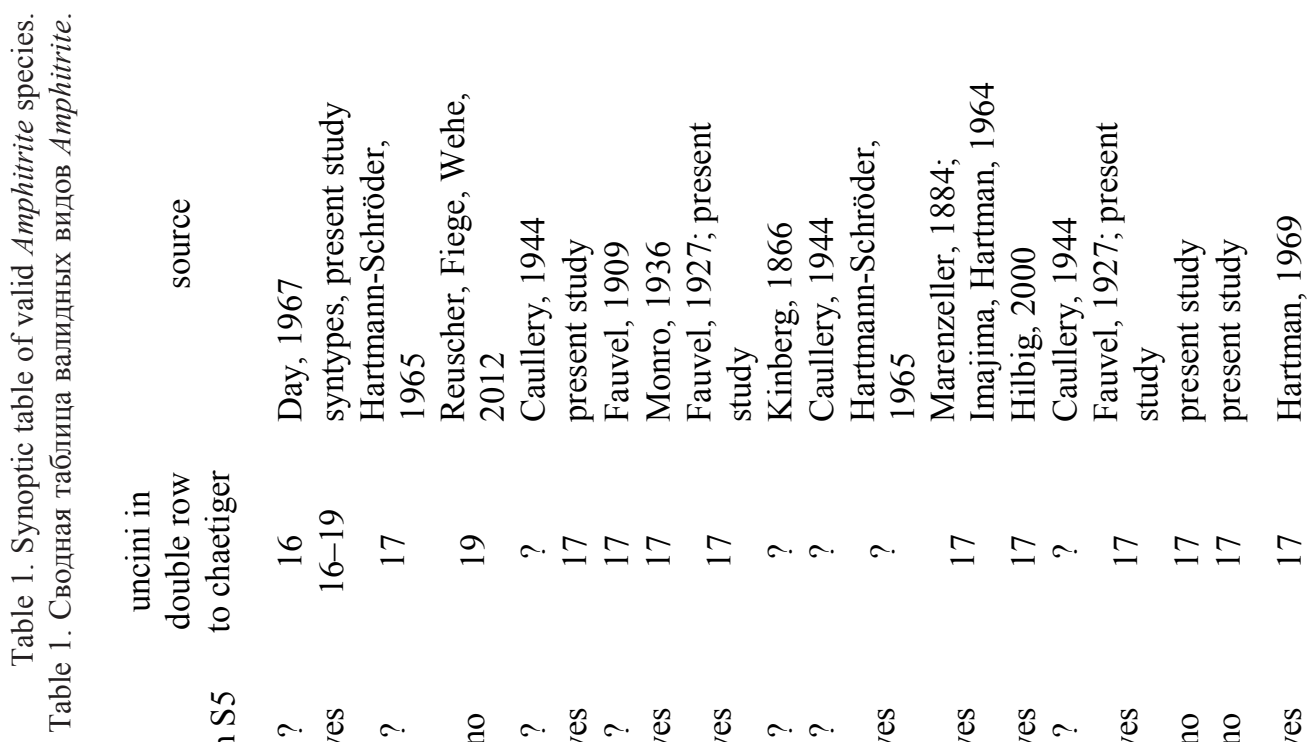

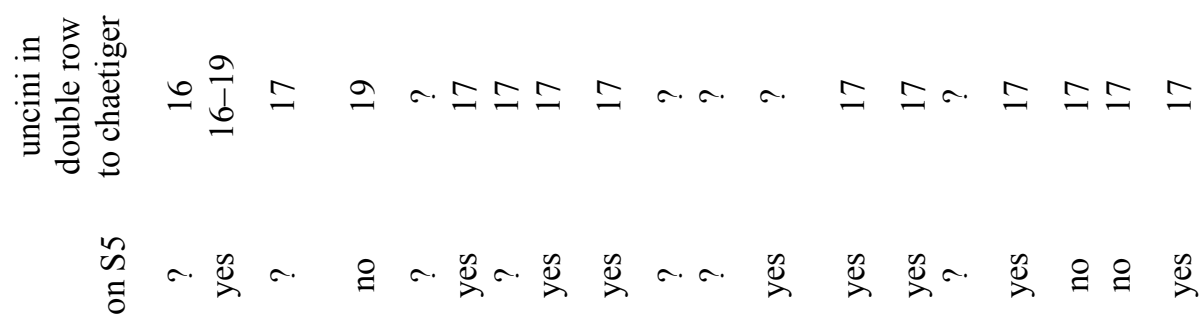
莺 ठ

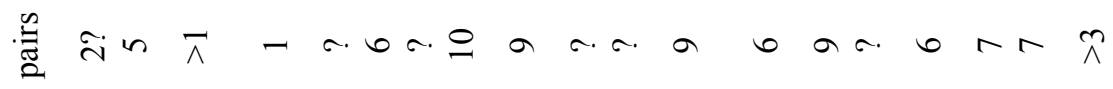

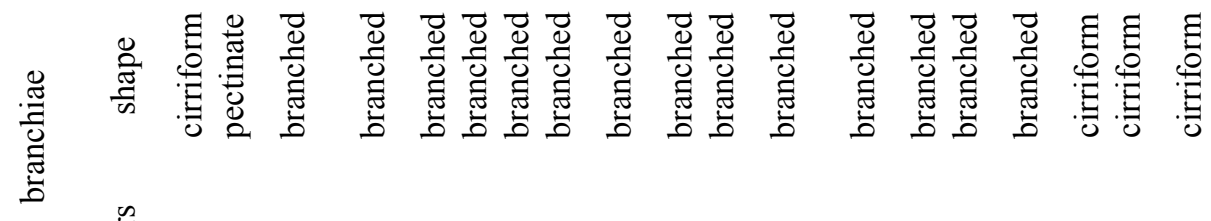

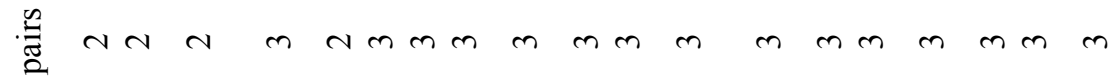

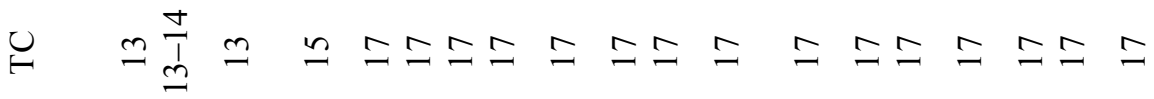

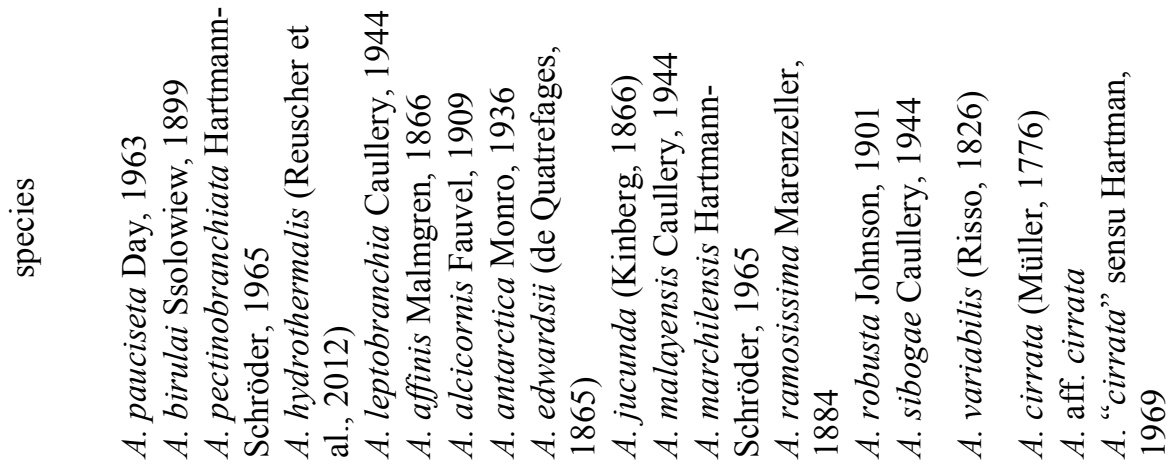




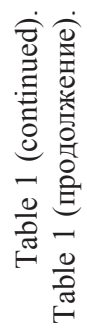

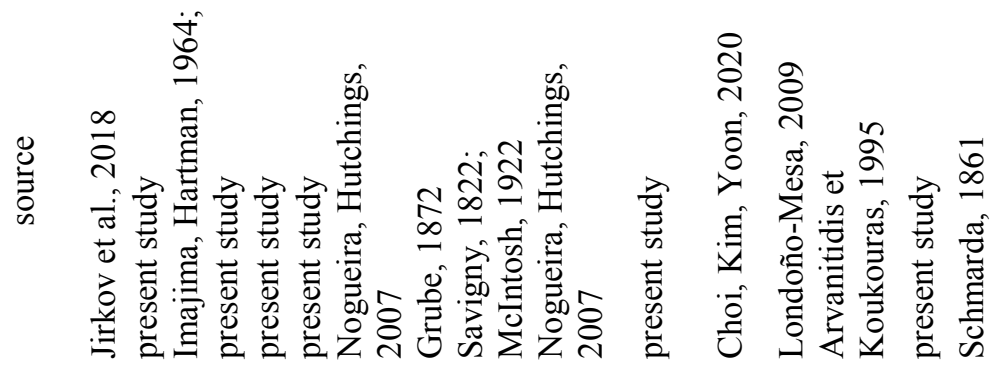

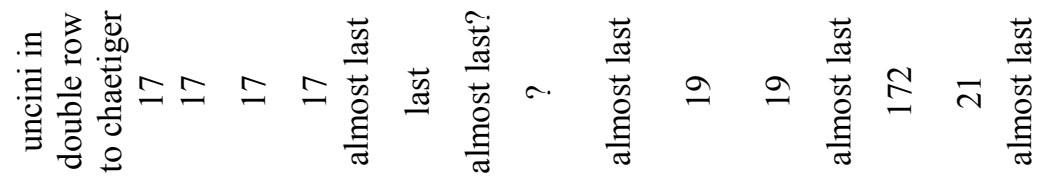

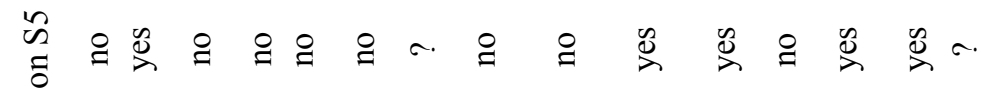
莺亏

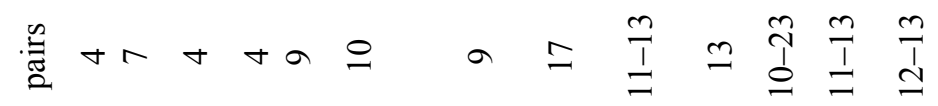

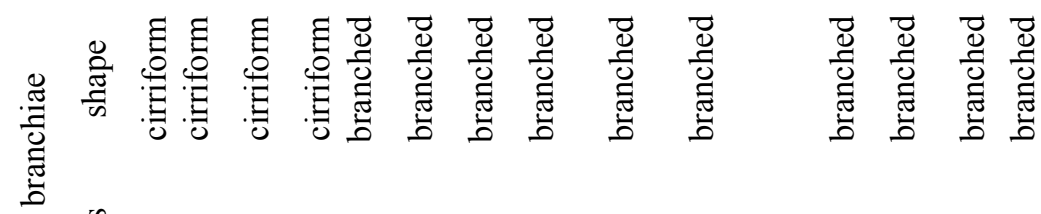

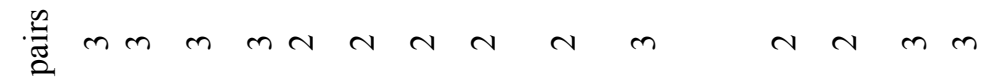

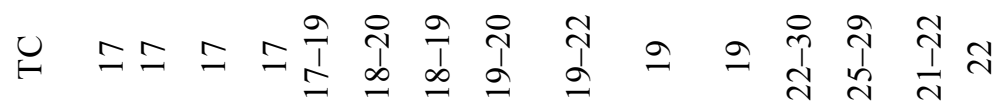

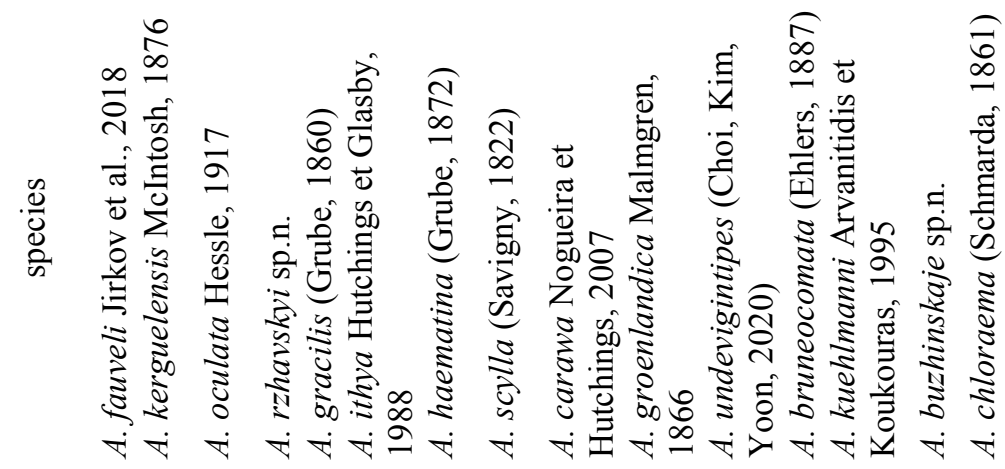




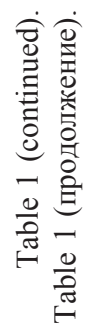

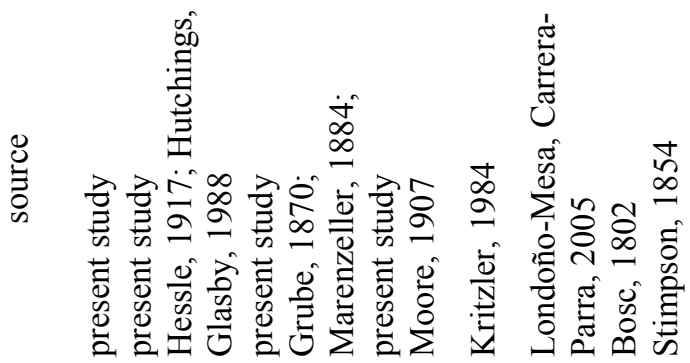

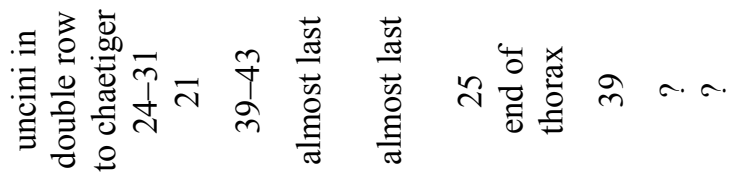

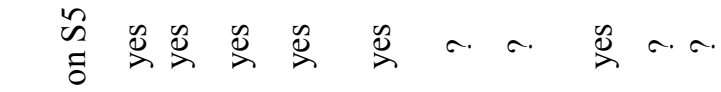

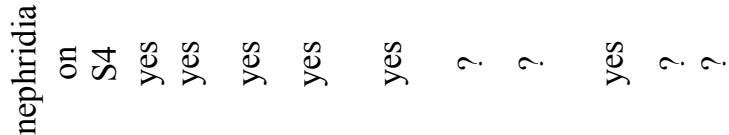

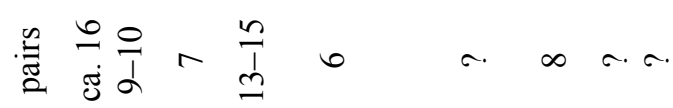

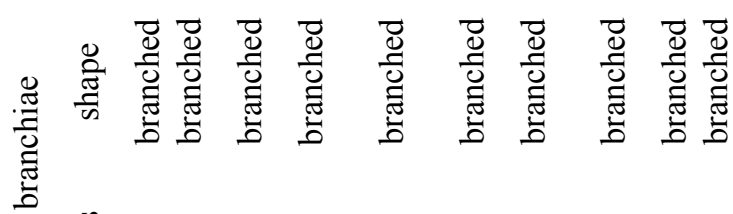

光 $n m n n m m n n$

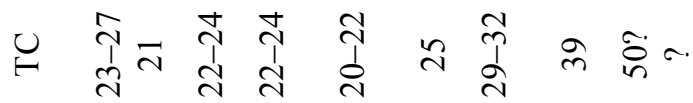

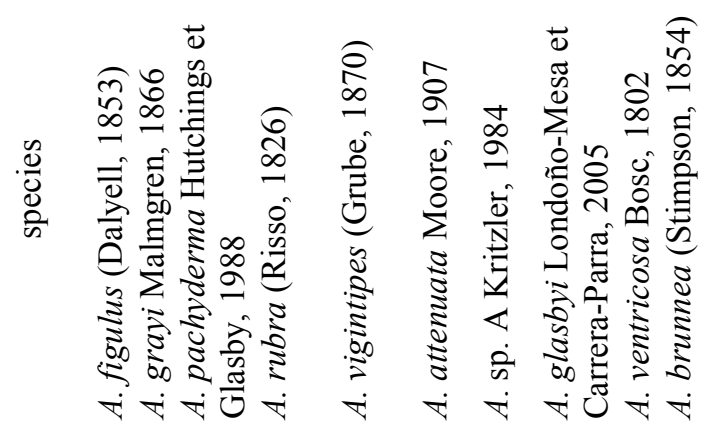


lis without any argumentation. The original description has no data on the number of segments and branchiae. The taxonomic status of species is not clear.

I agree with Nogueira (2008) that Terebella ornata Leidy, 1855 (type locality USA Rhode Island) seems not to belong to Amphitrite, due to the presence of uncini with shafts and branchiae that distinctly differ from other species of $\mathrm{Am}$ phitrite, resembling those of some Axionice sensu Jirkov \& Leontovich (2017). However, as I have not seen specimens of this species and existing descriptions are not complete, I cannot come to any conclusion; it does not seem reasonable to change the generic diagnosis to accommodate $T$. ornata.

Terebella viminalis Grube, 1855 (type localities Trieste and Palermo, Italy) was synonymised by Fauvel (1909) with Amphitrite variabilis without any argumentation. According to the original description, $T$. viminalis has three pairs of branchiae and $16 \mathrm{TC}$, while $A$. variabilis has $17 \mathrm{TC}$; its taxonomic status is not clear.

Several other species assigned to Amphitrite (some were initially described as Terebella Linnaeus, 1767) have been described from European waters in the XIX century (Delle Chiaje, 1828; Grube, 1838, 1855, 1860, 1863; Claparède, 1870). However, their original descriptions usually lack sufficient detail even to be sure about generic affiliation; they may be species of Amphitrite, Terebella or even Eupolymnia Verrill, 1900. These three genera differ in the shape of their notochaetae: straight serrated in Amphitrite (Figs 4D-G, 7A-C, 9E, 10A-C, 14A-C, 16A-C, 19D, 20E), geniculated serrated in Terebella (Fig. 27) and smooth in Eupolymnia (Fig. 30D), Amphitrite, Terebella (Fig. 26) and Eupolymnia (Fig. 29) are similar in external morphology, the only difference: Amphitrite (Figs 3B, 4B, 6B, 9B, 11B, 13B, 15B, 18B, 19B, 20B, 23D) and Terebella (Fig. 28B) have distinct ventral pads, limited to ventral surface, while Eupolymnia has ventral pads extending laterally and with blurred borders (, but this difference is overlooked earlier. Also these three genera have avicular uncini, but Eupolymnia differ by first row of thees above main fung: it consist from numerous much smaller teeth in Amphitrite (Figs 1, 3E, F, 4H, 5, 7D, E, 10D-E, 11E, 13C, D, 15D, E, 17D, E, 18C, 19D, 20E, G, 22, 25D, E) and Terebella (Fig. 30A-D) and only one or two comparatively big tooth in Eupolymnia (Fig. 31A-C, E). However, such details are totally absent in original descriptions published before the XX century, so the taxonomic status of these species cannot be solved without examination of types.

\section{Discussion of species ranges}

Species range is a good character to assist with identification. Taxonomically similar species may have different, usually complimentary, ranges. Usually, a species' range lies within a limited suite of ecological characters; for example, it is unlikely that the same species inhabits both intertidal and abyssal zones. A cirrata provides a good example. Previously, the species range was believed to include shallow Arctic and Mediterranean and deep Atlantic waters but our investigation shows that, in reality, $A$. cirrata s.str. inhabits only shallow Arctic and boreal waters, while the deep Atlantic and shallow Mediterranean are inhabited by two other, previously overlooked, species. A similar species distributional pattern probably produced the $A$. affinis $-A$. edwardsii $-A$. variabilis and shallow A. figulus - A. rubra groups: Arcticboreal-Mediterranean and boreal-Mediterranean species respectively. All species of these groups were reported from Mediterranean waters, but I failed to find more northern species in collections from the Mediterranean (specimens identified as $A$. affinis in reality are A. variabilis), while Mediterranean species were common, so I consider reports of $A$. affinis, A. edwardsii and A. figulus from the Mediterranean to be based on misidentifications.

A. birulai provides a quite different example. The range of this species is wider than that of any other species of the genus. It is common in waters with reduced salinity (estuaries, the White Sea), while it is uncommon in water with normal salinity. In low salinity waters, biomes 


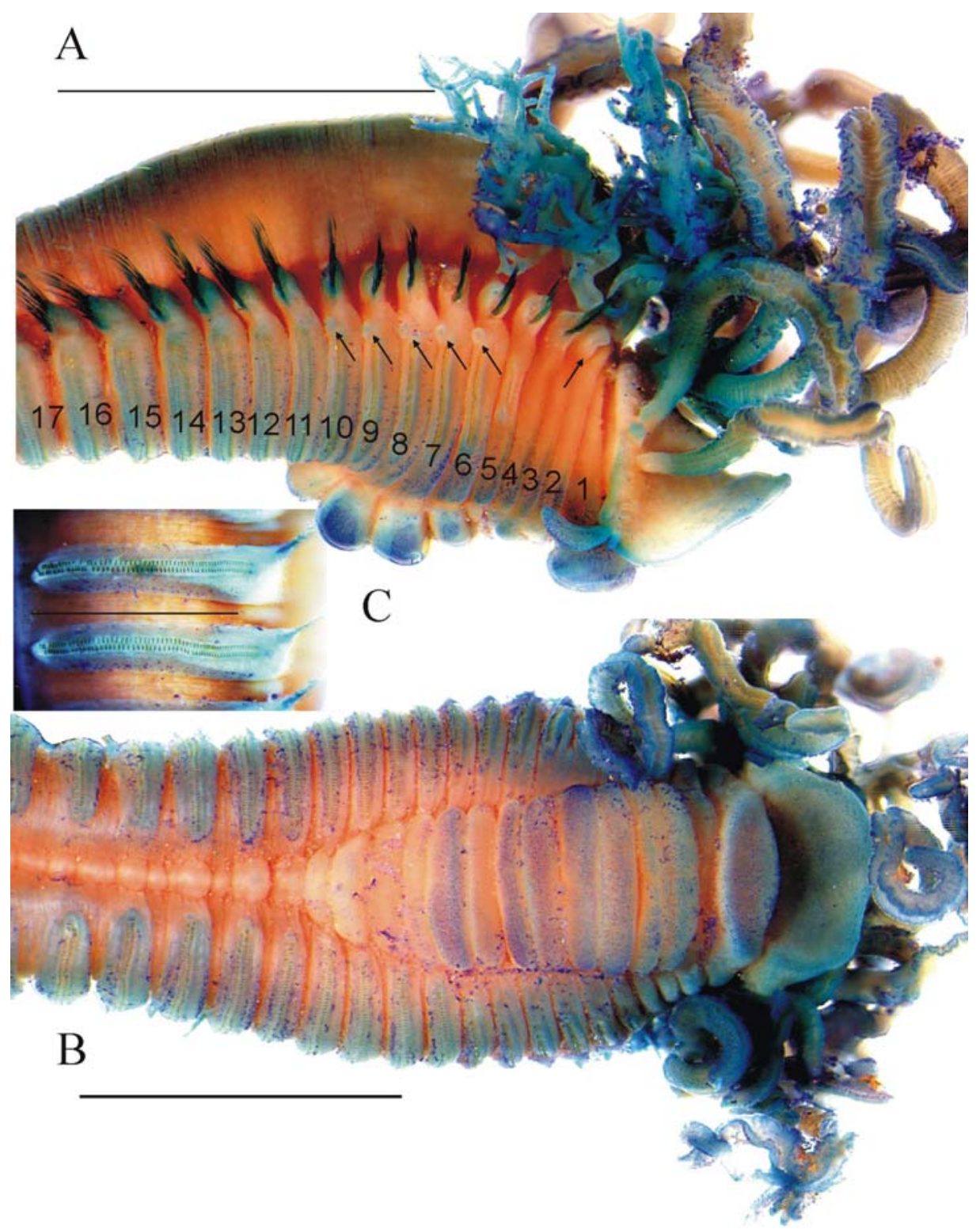

Fig. 27. Terebella lapidaria Linnaeus, 1767, external morphology. A — lateral view; B - ventral view; C middle body segements. All MNCN 5684. Scale bars: A, B $-2 \mathrm{~mm}, \mathrm{C}-1 \mathrm{~mm}$.

Рис. 27. Terebella lapidaria Linnaeus, 1767, external morphology. А - вид сбоку; В - вид с брюшной стороны; С - сегменты из середины тела. Все фото MNCN 5684. Масштаб: А, В - 2 мм, С - 1 мм.

are not in normal conditions, so A. birulai may be characterized as cenophobe species (Razumovskyi, 1999), which would explain the greater variation in some characters (the num- bers of TU and segments with neuropodia with uncini in double rows, tube structure, presence/ absence of eyespots) of this species compared to other Amphitrtite. 


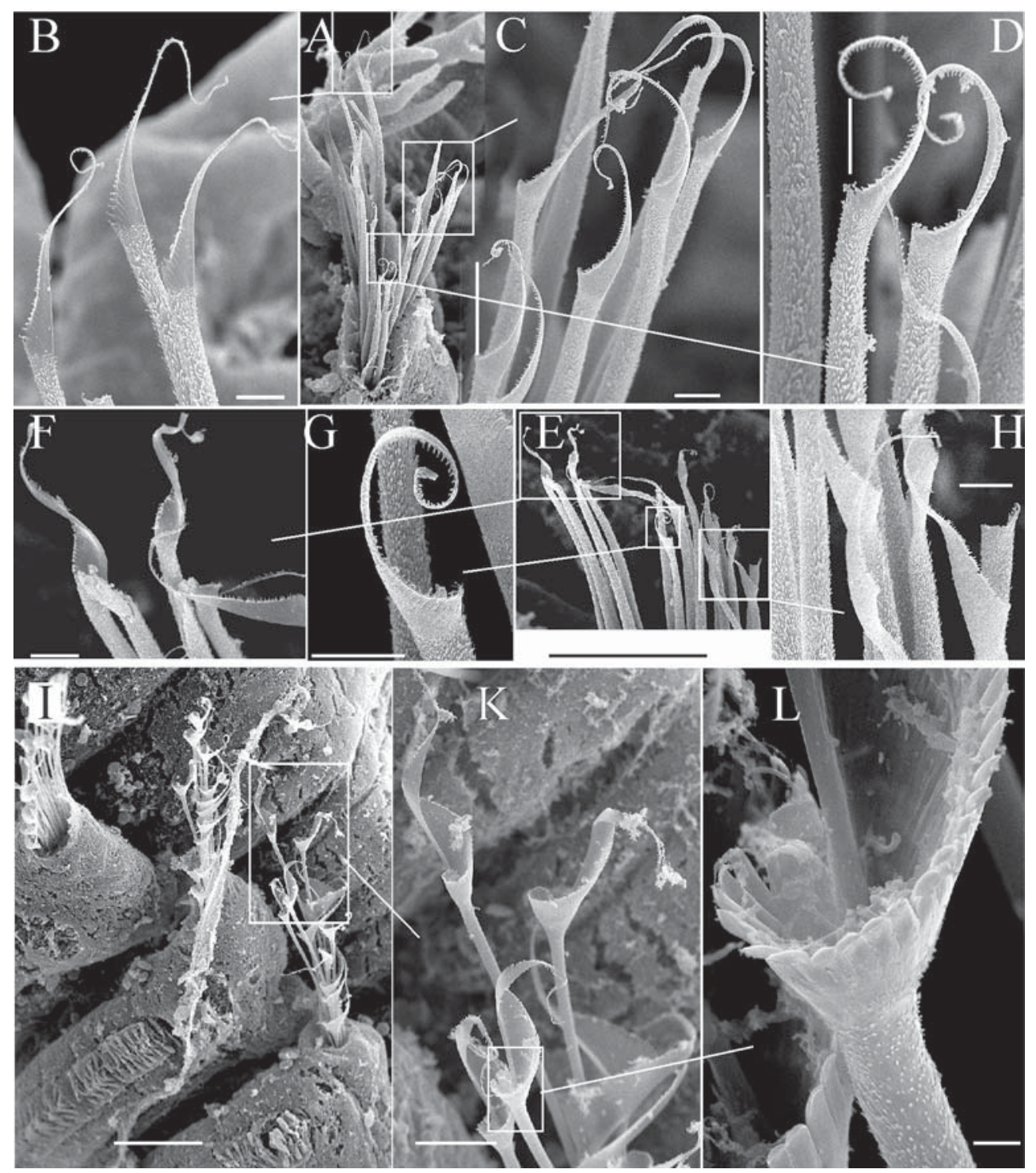

Fig. 28. Terebella lapidaria Linnaeus, 1767, notochaetae. A-D - TC1: C, D - details of A; E-H - TC15 F, $\mathrm{H}$ - details of E; I-L - TC near pygidium, $\mathrm{K}$ - details of I, L - details of I MNCN 5684. Scale bars: A, E, I $-0.1 \mathrm{~mm}, \mathrm{~B}-\mathrm{D}, \mathrm{F}-\mathrm{I}-10 \mu \mathrm{m}, \mathrm{K}-30 \mu \mathrm{m}, \mathrm{L}-3 \mu \mathrm{m}$.

Рис. 28. Terebella lapidaria Linnaeus, 1767, нотохеты. A-D - TC1: C, D - детали A; E-H - TC15 F, H - детали E; I-L — TC вблизи пигидиума, K - детали I, L - детали I MNCN 5684. Масштаб: A, E, I - 0,1 мм, B-D, F-I - 10 мкм, K-30 мкм, L - 3 мкм.

\section{Acknowledgements}

The author thanks Prof. V.V. Malakhov (Moscow State University) and Dr. A.F. Sazhin (PP Shirshov Institute) for the use of equipment for preparing photographs, Mr. D.J. Hall and
Dr. T.M. Worsfold (APEM) for the loan of specimens and access to the APEM collection, Dr. A.V. Sikorski for the loan of specimens from Akvaplan-niva, Dr. Marián Ramos, Principal Researcher of the "Fauna Ibérica XI" 


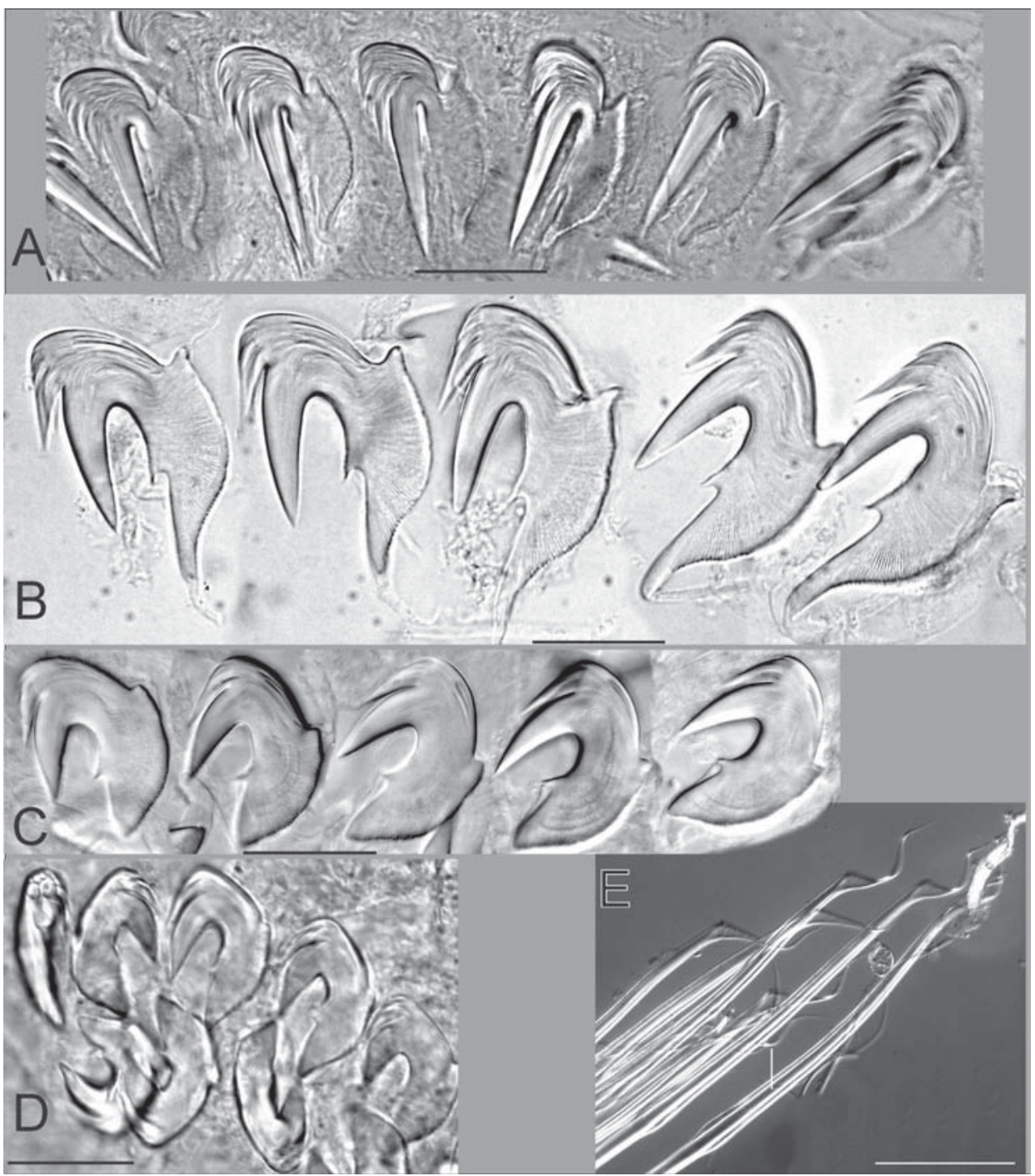

Fig. 29. Terebella lapidaria Linnaeus, 1767, uncini. A - TU1; B - TU2; C - TU13; D - TU50; E TC2. All MNCN 5684. Scale bars: A-D - $25 \mu \mathrm{m}, \mathrm{E}-0.1 \mathrm{~mm}$.

Рис. 29. Terebella lapidaria Linnaeus, 1767, uncini. A — TU1; B — TU2; C — TU13; D — TU50; E TC2. Bce MNCN 5684. Масштаб: A-D - 25 мкм, E - 0,1 мм.

project. Mr. D.J. Hall and Dr. T.M. Worsfold made edits to the English.

\section{Funding}

This work was supported by the Russian Science Foundation (grant number 14-50-00029) for investigation within the Russian border, by a State Research Program granted to Moscow
State University (project No. AAAA-A16116021660062-9 Hydrobiology Dept.), and "Fauna Ibérica XI — Polychaeta VI" (Reference: MICINN CGL2010-22267-C07-01). The SEM was performed with financial support from the Ministry of Education and Science of the Russian Federation. 


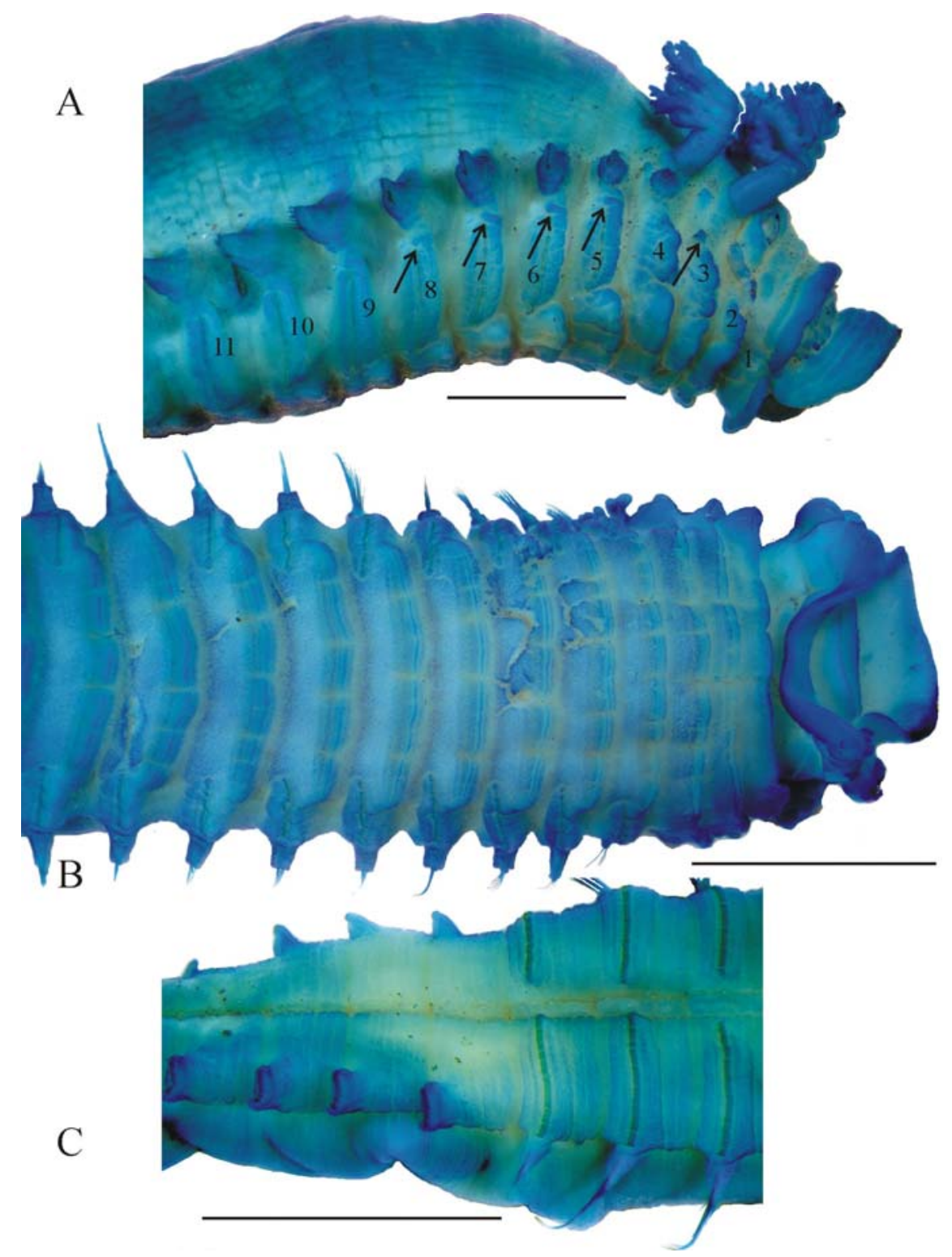

Fig. 30. Eupolymnia nesidensis (delle Chiaje, 1828), external morphology. A - lateral view, MNCN474; $\mathrm{B}$ - ventral view, MNCN476; C - thorax-abdomen border, MNCN476. Scale bars $2 \mathrm{~mm}$.

Рис. 30. Eupolymnia nesidensis (delle Chiaje, 1828), внешняя морфология. А — вид сбоку, MNCN474; В вид с брюшной стороны, MNCN476; C — граница торакса и абдомена, MNCN476. Масштаб 2 мм.

\section{References}

Alós C. 1984. Anélidos Poliquetos del Cabo de Creus. I. Rizomas de Posidonia oceanica // Cuadernos Marisqueiros (Actas del III Simposio Ibérico de Estudios del Bentos Marino) Vol.7. P.89-102.
Annenkova N.P. 1937. [Polychaete fauna of the northern part of the Japan Sea] // Issledovaniya fauny morei SSSR. Vol.23. P.139-199 [in Russian].

Annenkova N.P. 1938. [Polychaeta of the north Japan Sea and their horizontal and vertical distribution] // Trudy gidrobiologicheskoi ekspeditsii Zoologicheskogo instituta AN SSSR na Yaponskoe More v 1934 godu. 


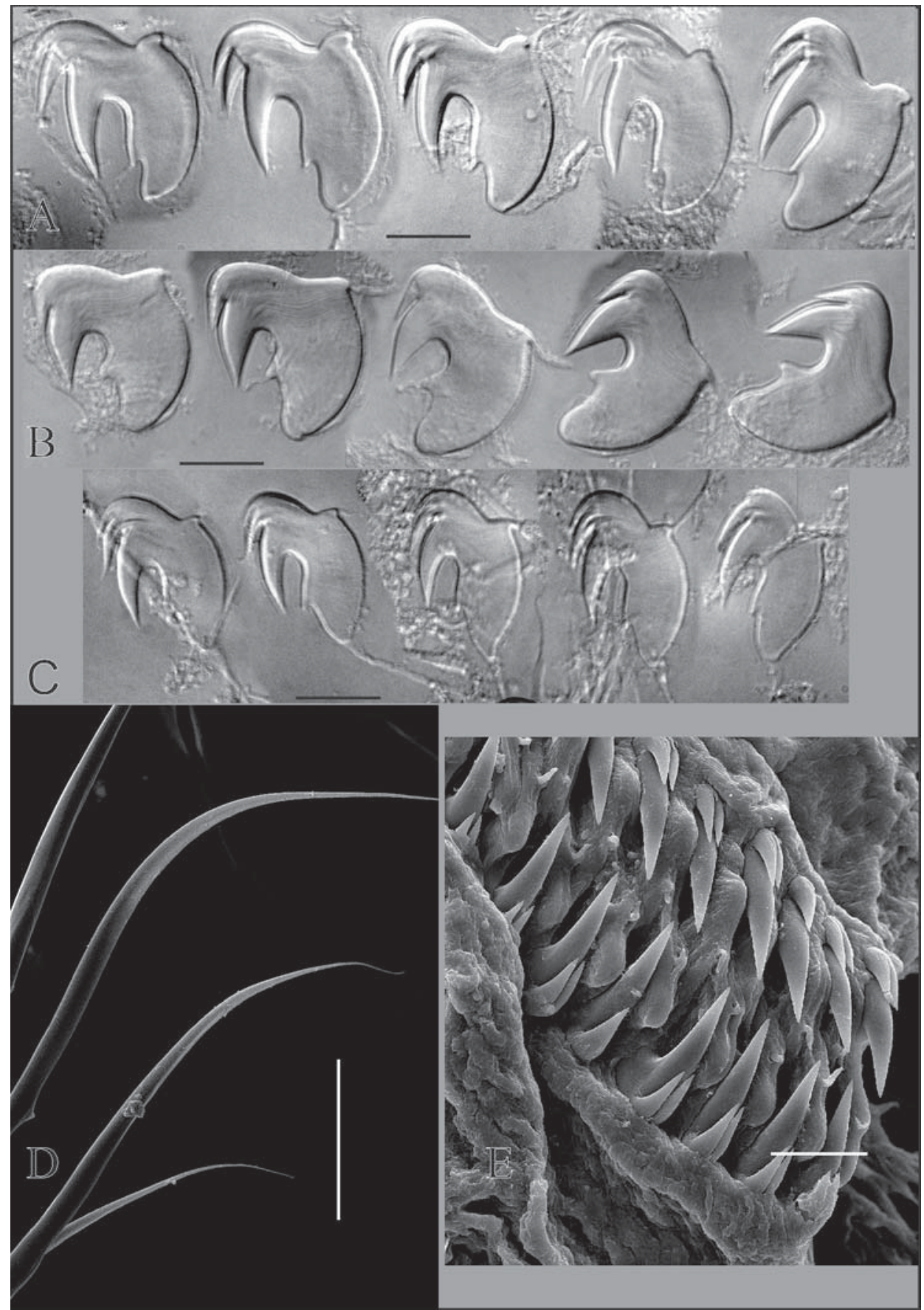

Fig. 31. Eupolymnia chaetae. A-D - Eupolymnia nesidensis (delle Chiaje, 1828), MNCN476: A — uncini TU1, B - uncini TU11, C - uncini AU15; D - tip of notochaeta; E - Eupolymnia nebulosa (Montagui, 1818), thoracal uncini. Scale bars: A-C $-20 \mu \mathrm{m}, \mathrm{D}-0.1 \mathrm{~mm}, \mathrm{E}-30 \mu \mathrm{m}$.

Рис. 31. Eupolymnia щетинки. A-D - Eupolymnia nesidensis (delle Chiaje, 1828), MNCN476: A uncini TU1, B - uncini TU11, C - uncini AU15; D - вершины нотохет; E - Eupolymnia nebulosa (Montagui, 1818), торакальные uncini. Масштаб: A-C - 20 мкм, D - 0,1 мм, E - 30 мкм. 
No.1. P.81-222 [in Russian].

Arvanitidis C., Koukouras A. 1995. Amphitritides kuehlmanni sp. nov. (Polychaeta, Terebellidae, Amphitritinae) from the Aegean Sea, with comments on the genus Amphitritides Augener// Ophelia. Vol.40. No.3. P.219-227.

Augener H. 1922. Ueber litorale Polychaeten von Westindien // Sitzungsberichte der Gesellschaft Naturforschende Freunde zur Berlin. Bd.3-5. S.38-53.

Banse K., Hobson K. 1968. Benthic polychaetes from Puget Sound, Washington, with remarks on four other species // Proceedings of the United States National Museum. Vol.125. No.3667. P.1-53.

Bosc L.A.G. 1802. Histoire naturelle des vers contenant leur description et leurs moeurs, avec figures dessinées d'après nature. Paris: De l'imprimerie de Guilleminet; chez Deterville. 324 p.

Buzhinskaja G.N. 1967. [Ecology of Polychaeta from the Posjet Bay (Sea of Japan)] // Issledovaniya fauny morei. Vol.5. No.13. P.78-124 [in Russian].

Castelli A., Bianchi C.N., Cantone G., Çinar M.E., Gambi M.C., Giangrande A., Sareri D.I., Lanera P., Licciano M., Musco L., Sanfilippo R., Simonini R. 2008. Annelida Polychaeta // Biologia marina mediterranea. Vol.15. No.suppl. P.323-373.

Caullery M. 1944. Polychetes Sedentaire de 1'Expedition du Siboga: Ariciidae, Spionidae, Chaetopteridae, Chlorhaemidae, Opheliidae, Oweniidae, Sabellariidae, Sternaspidae, Amphictenidae, Ampharetidae, Terebellidae // Siboga-Expeditie Uitkomsten op Zoologisch, Bonatisch, Oceanographisch en Geologisch gebied verzameld in Nederlandsch Oost-India 18991900. Vol.24 2 bis. P.1-204, 157 figures.

Chiaje S.d. 1828. Memorie sulla storia e notomia degli animali senza vertebre del Regno di Napoli. Vol.3. Stamperia della Societa Tipografica, Napoli. 232 p.

Choi H.K., Kim H., Yoon S.M. 2020. Neoamphitrite undevigintipes, a new terebellid species from South Korea (Annelida, Terebellida, Terebellidae) // ZooKeys. Vol.943. P.41-51. doi: 10.3897/zookeys.943. 48760.

Claparède É. 1869. Les Annélides Chétopodes du Golfe de Naples. Seconde partie. Ordre IIme. Annélides Sédentaires (Aud. et Edw.) // Mémoires de la Société de Physique et d'Histoire Naturelle de Genève. Vol.20. No.1. P.1-225.

Claparède É. 1870. Les annélides chétopodes du Golfe de Naples. Supplement // Mémoires de la Société de physique et d'histoire naturelle de Genève. Vol.20. No.2. P.365-542.

Dalyell J.G. 1853. The Powers of the Creator displayed in the Creation: or, observations on life amidst the various forms of the humbler tribes of animated nature with practical comments and illustrations. London: John van Voorst. 359 p.

Day J.H. 1967. A monograph on the Polychaeta of Southern Africa. Vol.2. Sedentaria. London. British Museum (Natural History). 416 p.

Ehlers E. 1887. Reports on the results of dredging, under the direction of L.F. Pourtalès, during the years 1868 1870, and of Alexander Agassiz, in the Gulf of Mexico (1877-78), and in the Caribbean Sea (1878-79), in the U.S. Coast Survey steamer "Blake", Lieut-Com. C.D. Sigsbee, U.S.N. and Commander J.R. Bartlett,
U.S.N., commanding. XXXI. Report on the Annelids // Memoirs of the Museum of Comparative Zoology at Harvard College. Vol.15. P.1-335.

Ehlers E. 1901. Die Polychaeten des magellanischen und chilenischen Strandes. Ein faunistischer Versuch. Festschrift zur Feier des Hundertfünfzigjährigen Bestehens Königlichen Gesellschaft der Wissenschaften zu Göttingen Abhandlungen der Mathematisch-Physikalischen Klasse. Berlin: Weidmannsche Buchhandlung. $232 \mathrm{~S}$.

Fauchald K. 1977. The polychaete worms. Definitions and keys to the orders, families and genera // Natural History Museum of Los Angeles County. Science Series. Vol.28. 188 p.

Faulwetter S., Simboura N., Katsiaras N., Chatzigeorgiou G., Arvanitidis C. 2017. Polychaetes of Greece: an updated and annotated checklist // Biodiversity Data Journal. No.5: e20997.

Fauvel P. 1909. Deuxième note préliminaire sur les polychètes provenant des campagnes de l'Hirondelle et de la Princesse-Alice, ou déposées dans la Musée Océanographique de Monaco // Bulletin de l'Institute Océanographique de Monaco. Vol.142. P.1-76.

Fauvel P. 1927. Polychètes sédentaires. Addenda aur Errantes, Archiannélides. Myzostomaires // Faune de France. Paris. Vol.16. 404 p.

Grainger E.H. 1954. Polychaetous annelids of Ungava Bay, Hudson Strait, Frobisher Bay and Cumberland Sound // Journal of the Fisheries Research Board of Canada. Vol.11. No.5. P.507-528.

Grube A.E. 1838. Anatomie und Physiologie der Kiemenwuermer. Königsberg. $77 \mathrm{~S}$.

Grube A.E. 1855. Beschreibungen neuer oder wenig bekannter Anneliden // Archiv fûr Naturgeschichte. Bd.21. H.1. S.81-136.

Grube A.E. 1860. Beschreibung neuer oder wenig bekannter Anneliden. Fünfter Beitrag // Archiv für Naturgeschichte. Bd.26. H.1. S.71-118.

Grube A.E. 1863. Beschreibung neuer oder wenig bekannter Anneliden. Beitrag: Zahlreiche Gattungen // Archiv für Naturgeschichte. Bd.29. S.37-69.

Grube A.E. 1870. Beschreibungen neuer oder weniger bekannter von Hrn. Ehrenberg gesammelter Anneliden des rothen Meeres // Monatsbericht der Koniglich Preussischer Akademie der Wissenschaften zu Berlin, 1869. S.484-521.

Grube A.E. 1872. Übersicht der bisher bescchrieben Terebellen und einige Serpulaceen // Jahresbreicht der Schlesische Gesellschaft für vaterlandische Cultur. Bd.49. S.48-53.

Hartman O. 1959. Catalogue of the polychaetous annelids of the world. Part I and II // Allan Hancock Foundation Publications. Occasional Paper. Vol.23. P.1-628.

Hartman O. 1969. Atlas of the sedentariate polychaetous annelids from California. Los Angeles, CA. California Allan Hancock Foundation University of Southern California. 812 p.

Hartman O. 1959. Catalogue of the Polychaetous Annelids of the World. Occasional Papers of the Allan Hancock Foundation. $628 \mathrm{p}$.

Hartmann-Schröder G. 1965. Die Polychaeten des Sublitorals // Mitteilungen aus dem Hamburgischen zoologischen Museum und Institut. Bd.62. S.59-305. 
Hartmann-Schröder G. 1971. Die Tierwelt Deutschlands un der angernzenden Meeresteile nach ihren Merkmalen und nach ihrer Lebensweise. Annelida, Borstenwürmer, Polychaeta. Jena: Gustav Fischer. 594 S.

Hartmann-Schröder G. 1996. Die Tierwelt Deutschlands un der angernzenden Meeresteile nach ihren Merkmalen und nach ihrer Lebensweise. Annelida, Borstenwürmer, Polychaeta. Jena: Gustav Fischer. 648 S.

Hessle C. 1917. Zur Kenntnis der terebellomorphen Polychaeten // Zoologiska bidrag från Uppsala. Bd.5. S.39-258.

Hilbig B. 2000. 9. Family Terebellidae Grube, 1851 // J.A. Blake, B. Hilbig, P.V. Scott (eds.). Taxonomic Atlas of the Benthic Fauna of the Santa Maria Basin and Western Santa Barbara Channel, Vol.7 - The Annelida. Part 4. Polychaeta: Fabelligeridae to Sternaspidae: Santa Barbara: Santa Barbara Museum of Natural History. P. 31-294.

Hobson K.D., Banse K. 1981. Sedentariate and archiannelid polychaetes of British Columbia and Washington. Ottawa: Department of Fisheries and Oceans Bulletin. $144 \mathrm{p}$.

Holthe T. 1976. Paramphitrite tetrabranchia gen. et sp. nov. a new terebellid polychaet from Western Norway // Sarsia. Vol.61. No.1. P.59-62.

Holthe T. 1986. Polychaeta Terebellomorpha // Marine Invertibrates of Scandinavia. Vol.7. $192 \mathrm{p}$.

Hsieh H.L. 1994. Amphitrite lobocephala, a new species (Polychaeta: Terebellidae) from Taiwan // Proceedings of the Biological Society of Washington. Vol.107. No.3. P.517-523.

Hutchings P.A., Murray A. 1984. Taxonomy of polychaetes from the Hawkesbury River and the southern estuaries of New South Wales, Australia // Records of the Australian Museum. Suppl.3. P.1-118.

Hutchings P.A., Glasby C.J. 1988. The Amphitritinae (Polychaeta: Terebellidae) from Australia // Records of the Australian Museum. Vol.40. P.1-60.

Hutchings P.A., Glasby C.J. 1995. Description of the widely reported terebellid polychaetes Loimia medusa (Savigny) and Amphitrite rubra (Risso) // Mitteilungen aus dem Hamburgischen zoologischen Museum und Institut. Vol.92. P.149-154.

Hutchings P.A., Nogueira J.M.d.M., Carrerete O. 2017. Terebellidae s.1: Polycirridae Malmgren, 1866, Terebellidae Johnston, 1846, Thelepodidae Hessle, 1917, Trichobranchidae Malmgren, 1866, and Telothelepodidae Nogueira, Fitzhugh, Hutchings, 2013 // SchmidtRhaesa R.G., Glaubrecht M., Kristensen N.P., Prendini L., Purschke G., Richter S., Westheide W., and Leschen R. (eds.). Handbook of zoology online. A natural history of the phyla of the animal kingdom. Annelida: Polychaetes. https://www.degruyter.com/ view/zoology/bp_029147-6_68: De Gruyter. p. 64.

ICZN International Code of Zoological Nomenclature. http://www.nhm.ac.uk/hosted-sites/iczn/code/

Imajima M., Hartman O. 1964. The polychaetous annelids of Japan. Part II. Los Angeles, California. The University of Southern California Press. Allan Hancock Foundation publications occasional paper. $452 \mathrm{p}$.

Jirkov I.A. 1989. [Bottom fauna of the USSR seas. Polychaeta]. Moscow. Moscow State University Press. 141 p. [In Russian]
Jirkov I.A. 2001. [Polychaeta of the Arctic Ocean]. Moscow. Yanus-K. 632 p. [In Russian]

Jirkov I.A., Leontovitch M.K. 2013. Identification keys for Terebellomorpha (Polychaeta) of the eastern Atlantic and the North Polar basin // Invertebrate Zoology. Vol.10. No.2. P.217-243.

Jirkov I.A., Leontovitch M.K. 2017. Review of genera within the Axionice/Pista complex (Polychaeta, Terebellidae), with discussion of the taxonomic definition of other Terebellidae with large lateral lobes // Journal of the Marine Biological Association of the United Kingdom. Vol.97. No.5. P.911-934.

Jirkov I.A., Ravara A., Cunha M.R. 2018. New Amphitrite (Polychaeta: Terebellidae) from Bay of Biscay and Gulf of Cadiz (NE Atlantic) // Invertebrate Zoology. Vol.15. No.1. P.85-91.

Johnson H.P. 1901. The Polychaeta of the Puget Sound region // Proceedings of the Boston Society for Natural History. Vol.29. No.18. P.381-437.

Johnston G. 1846. An index to the British Annelides // Annals and Magazine of Natural History. Vol.1. P.433462.

Kinberg J.G.H. 1866. Annulata nova // Öfversigt af Königlich Vetenskapsakademiens förhandlingar, Stockholm. Bd1.23. H.9. S.337-357.

Kritzler H. 1984. Family Terebellidae Grube 1950 // Uebelacker J.M., Johnson P.G. (eds.). Taxonomic Guide to the Polychaetes of the Northern Gulf of Mexico. Mobile Alabama: Barry A. Vittor \& Associates, Inc. Vol.7. P. 53-124.

Leidy J. 1855. Contributions towards a knowledge of the marine Invertebrate fauna of the coasts of Rhode Island and New Jersey // Journal of the Academy of Natural Sciences of Philadelphia. Vol.3(2). No.11. P.135-152.

Linnaeus C. 1767. Caroli Linnaei... Systema naturae per regna tria naturae: secundum classes, ordines, genera, species, cum characteribus, differentiis, synonymis, locis. 1. Regnum Animale. Holmiae [Stockholm]. Laurentii Salvii. 1-532 [1766], 1533-1327 [1767] p.

Londoño-Mesa M.H. 2009. Terebellidae (Polychaeta: Terebellida) from the Grand Caribbean region // Zootaxa. Vol.2320. P.1-93.

Londoño-Mesa M.H., Carrera-Parra L.F. 2005. Terebellidae (Polychaeta) from the Mexican Caribbean with description of four new species // Zootaxa. Vol.1057. P. 1-44.

Malmgren A.J. 1866. Nordiska Hafs-Annulater // Öfversigt af Königlich Vetenskapsakademiens Förhandlingar, Stockholm. Bd.22. H.3. S.355-410.

Marenzeller E.v. 1884. Südjapanische Anneliden. II. Ampharetea, Terebellacea, Sabellacea, Serpulacea // Denkschriften der Akademie der Wissenschaften, Wien. Bd.49. H.2. S.197-224.

McIntosh W.C. 1875. The marine invertebrates and fishes of St. Andrews. Edinburgh.

McIntosh W.C. 1922. A monograph of the British marine annelids. Vol.IV. Pt.1. Polychaeta Hermellidae to Sabellidae. London: Ray Society. 170-250 p.

Mikac B. 2015. A sea of worms: polychaete checklist of the Adriatic Sea // Zootaxa. Vol.3943. No.1. P.1-17.

Monro C.C.A. 1930. Polychaete worms // Discovery Reports, Cambridge. Vol.2. P.1-222.

Monro C.C.A. 1936. Polychaete worms II // Discovery Reports, Cambridge. Vol.12. P.59-197. 
Montagu G. 1819. Descriptions of five British species of the genus Terebella // Transactions of the Linnean Society of London. Vol.12. P.340-344.

Moore J.P. 1907. Descriptions of new species of Polychaeta from the southeastern coast of Massachusetts // Proceedings of the Academy of Natural Sciences, Philadelphia. Vol.58. P.501-508.

Müller O.F. 1771. Von Würmern des süssen und salzigen Wassers. H. Mumme and Faber. 200 S.

Müller O.F. 1776. Zoologiae Danicae Prodromus seu Animalium Daniae et Norvegiae indigenarum characteres, nomina, et synonyma imprimis popularium. Hafniae, Typiis Hallageriis. xxii +274 p.

Nogueira J.M.M. 2008. Review of some terebelliform polychaetes (Polychaeta: Terebelliformia) at the Yale Peabody Museum // Bulletin of the Peabody Museum of Natural History. Vol.49. No.2. P.209-234.

Nogueira J.M.M., Fitzhugh K., Hutchings P.A. 2013. The continuing challenge of phylogenetic relationships in Terebelliformia (Annelida: Polychaeta) // Invertebrate Systematics. Vol.27. P.186-238.

Nogueira J.M.M., Hutchings P.A. 2007. New species of terebellid polychaetes (Polychaeta: Terebellidae) from Australia // Zootaxa. Vol.1473. P.1-24.

Nogueira J.M.M., Hutchings P.A., Fukuda M.V. 2010. Morphology of terebelliform polychaetes (Annelida: Polychaeta: Terebelliformia), with a focus on Terebellidae // Zootaxa. Vol.2460. 185 pp.

Papazacharias A. 1991. [Ecological study of the soft substratum macrofauna in the infralittoral and circalittoral zone of the Gulf of Kavala. PhD thesis. Aristotle University of Thessaloniki. 204 p.

Parapar J., Besteiro C., Urgorri V. 1992. Primera cita en el litoral ibérico de Paramphitrite tetrabranchia Holthe, 1976(Polychaeta, Terebellidae)// Miscelánia Zoológica. Vol.15. P.63-68.

Pettibone M.H. 1954. Marine Polychaete worms from Point Barrow, Alaska, with additional records from the North Atlantic and North Pacific // Proceedings of the United States National Museum. Vol.103. No.3324. P.203-355.

Pettibone M.H. 1956. Marine polychaete worms from Labrador // Proceedings of the United States National Museum. Vol.105. No.3361. P.531-584.

Quatrefages A.d. 1866 [imprint date 1865]. Annélides et Géphyriens: histoire naturelle des Annelés marins et d'eau douce. 794 p.

Razumovsky C.M. 1999. [Selected works]. Moscow. KMK Scientific Press. 599 p. [In Rissian]

Read G., Fauchald K.E. 2020a. World Polychaeta database. Amphitrite Müller, 1771. Accessed 2020-03-07.

Read G., Fauchald K.E. 2020b. World Polychaeta database. Neoamphitrite Hessle, 1917. Accessed 2020-03-07.

Read G., Fauchald K.E. 2020c. World Polychaeta database. Amphitrite grayi Malmgren, 1866. Accessed 2020-03-07.

Read G., Fauchald K.E. 2020d. World Polychaeta database. Neoamphitrite grayi (Malmgren, 1866). Accessed 2020-03-07.

Read G., Fauchald K.E. 2020e. World Polychaeta database. Amphitrite edwardsii (Quatrefages, 1866). Accessed 2020-03-07.
Read G., Fauchald K.E. 2020f. World Polychaeta database. Neoamphitrite edwardsi (Quatrefages, 1865). Accessed 2020-03-07.

Read G., Fauchald K.E. 2020g. World Polychaeta database. Neoamphitrite affinis antarctica (Monro, 1936). Accessed 2020-03-07.

Read G., Fauchald K.E. 2020h. World Polychaeta database. Nereis cirrosa Linnaeus, 1767. Accessed 202003-07.

Read G., Fauchald K.E. 2020i. World Polychaeta database. Amphitrite cirrata Müller, 1776. Accessed 202003-07.

Reuscher M., Fiege D., Wehe T. 2012. Terebellomorph polychaetes from hydrothermal vents and cold seeps with the description of two new species of Terebellidae (Annelida: Polychaeta) representing the first records of the family from deep-sea vents // Journal of the Marine Biological Association of the United Kingdom. Vol.92. No.5. P.997-1012.

Risso A. 1826. Histoire naturelle des principales productions de l'Europe Méridionale et particulièrement de celles des environs de Nice et des Alpes Maritimes. Paris. Levrault. 480 p.

Savigny J.-C. 1822. Système des annélides, principalement de celles des côtes de l'Égypte et de la Syrie, offrant les caractères tant distinctifs que naturels des Ordres, Familles et Genres, avec la Description des Espèces. Paris. Description de l'Égypte ou Recueil des Observations et des Recherches qui ont été faites en Égypte pendant l'Expédition de l'Armée Française, publié par les Ordres de sa Majesté l'Empereur Napoléon le Grand, Histoire Naturelle. 128 p.

Schmarda L.K. 1861. Neue Wirbellose Thiere: Beobachted und Gesammelt auf einer Reise um die Erde 1853 bis 1857. Turbellarien, Rotatorien und Anneliden. Leipzig: Verlag von Wilhelm Engelmann. $161 \mathrm{~S}$.

Ssolowiew M. 1899. Polychaeten-Studien. Die Terebelliden des Weissen Meeres // Annuaire du musée zoologique de l'Académie impériale des sciences de St.-Pétersbourg. Vol.4. No.2. P.179-220.

Tzetlin A.B., Jirkov I.A., Markelova N.P. 1983. [Polychaeta of the White Sea (Spiomorpha, Drilomorpha, Terebellomorpha)]//Sbornik trudov Zoologicheskogo muzeya MGU. Moscow. Vol.20. P.166-186 [in Russian].

Uschakov P.V. 1955. [Polychaeta of the Far Eastern Seas of the USSR] // Opredeliteli po faune SSSR, izdavaemye Zoologicheskim Institutom AN SSSR. Moscow, Leningrad. AN SSSR Publ. Vol.56. 445 p. [In Russian]

Verrill A.E. 1900. Additions to the Turbellaria, Nemertina, and Annelida of the Bermudas, with revisions of some New England genera and species // Transactions of the Connecticut Academy of Arts and Sciences. Vol.10. No.2. P.595-671.

Zatsepin V.I. 1948. [Class Polychaeta] // N.S. Gaevskaja (ed.). Opredelitel' fauny i flory severnykh morei SSSR. Moscow: Sovetskaya Nauka. P.94-167 [in Russian].

Responsible editor T.A. Britaev 